\title{
1994 Solid Waste Forecast Container Volume Summary
}

K. J. Templeton

J. L. Clary

Pacific Northwest Laboratory

Date Published

September 1994

Prepared for the U.S. Department of Energy Office of Environmental Restoration and Waste Management

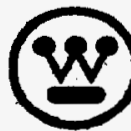

Hanford Operations and Engineering Contractor for the

U.S. Department of Energy under Contract DE-AC06-87RL10930 


\section{RELEASE AUTHORIZATION}

Document Number: WHC-EP-0803

Document Title: $\quad 1994$ Solid Waste Forecast Container Volume Summary

Release Date: $\quad 9 / 7 / 94$

This document was reviewed following the procedures described in WHC-CM $-3-4$ and is:

APPROVED FOR PUBLIC RELEASE

WHC Information Release Administration Specialist:

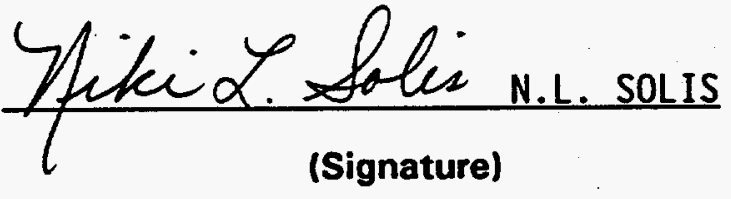

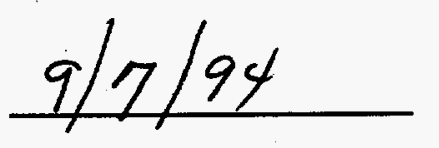

(Date) 


\section{DISCLAIMER}

This report was prepared as an account of work sponsored by an agency of the United States Government. Neither the United States Government nor any agency thereof, nor any of their employees, make any warranty, express or implied, or assumes any legal liability or responsibility for the accuracy, completeness, or usefulness of any information, apparatus, product, or process disciosed, or represents that its use would not infringe privately owned rights. Reference herein to any specific commercial product, process, or service by trade name, trademark, manufacturer, or otherwise does not necessarily constitute or imply its endorsement, recommendation, or favoring by the United States Government or any agency thereof. The views and opinions of authors expressed herein do not necessarily state or reflect those of the United States Government or any agency thereof. 


\section{DISCLAIMER}

Portions of this document may be illegible in electronic image products. Images are produced from the best available original document. 
WHC-EP-0803

\section{EXECUTIVE SUMMARY}

This report describes a 30-year forecast of the solid waste volumes by container type. The volumes described are low-level mixed waste (LLMW) and transuranic/transuranic mixed (TRU/TRUM) waste. These volumes and their associated container types will be generated or received at the U.S. Department of Energy Hanford Site for storage, treatment, and disposal at Westinghouse Hanford Company's Solid Waste Operations Complex (SWOC) ${ }^{1}$ during a 30-year period from FY 1994 through FY 2023.

The forecast data for the 30-year period indicates that approximately $307,150 \mathrm{~m}^{3}$ of LLMW and TRU/TRUM waste will be managed by the SWOC. The main container type for this waste is 55-gallon drums, which will be used to ship $36 \%$ of the LLMW and TRU/TRUM waste. The main waste generator forecasting the use of 55-gallon drums is Past Practice Remediation. This waste will be generated by the Environmental Restoration Program during remediation of Hanford's past practice sites. Although Past Practice Remediation is the primary generator of 55-gallon drums, most waste generators are planning to ship some percentage of their waste in 55-gallon drums.

Long-7ength equipment containers (LECs) are forecasted to contain $32 \%$ of the LLMW and TRU/TRUM waste. The main waste generator forecasting the use of LECs is the Long-Length Equipment waste generator, which is responsible for retrieving contaminated long-length equipment from the tank farms.

Boxes are forecasted to contain $21 \%$ of the waste. These containers are primarily forecasted for use by the Environmental Restoration Operations - D\&D of Surplus Facilities waste generator. This waste generator is responsible for the solid waste generated during decontamination and decommissioning (D\&D) of the facilities currently on the Surplus Facilities Program Plan.

The remaining LLMW and TRU/TRUM waste volume is planned to be shipped in casks and other miscellaneous containers. Casks wi1l be used for $7 \%$ of the waste, and miscellaneous containers will be used for $4 \%$ of the waste. Casks will be used primarily by a tank farm low-level waste pretreatment facility, which is responsible for a pilot test program to pretreat tank waste supernatant for the low-level waste treatment facility. Although the original facility for which this project was planned has been terminated, it is assumed that some sort of pretreatment will still be required prior to final stabilization of the tank waste. Therefore, the volumes estimated for the pretreatment facility have been included in this report, but the original 1993 forecast volumes have been delayed eight years to correspond to the startup of the tank farm low-level treatment facility established by the revised Tri-Party Agreement.

Data presented in this report establish a starting point for solid waste management planning. It is recognized that forecast estimates will vary (typically increasing) as facility planning and missions continue to change and become better defined, but the information presented still provides useful

1 The SWOC is defined for this report to included the existing Central Waste Complex and future facilities as identified in the Solid Waste Technical Baseline Description, WHC-SD-WM-RTP-000, Rev. 0. 
insight into Hanford's future solid waste management requirements. Solid waste management facilities will continue to provide adequate treatment, storage, and disposal through existing and planned solid waste facilities. The information presented within this document will be appropriately incorporated into the solid waste technical baseline. 


\section{CONTENTS}

EXECUTIVE SUMMARY .................... i ii

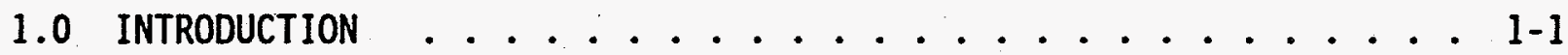

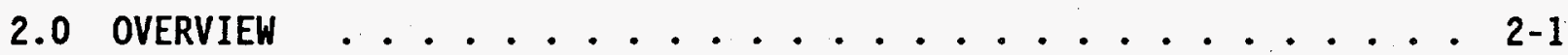

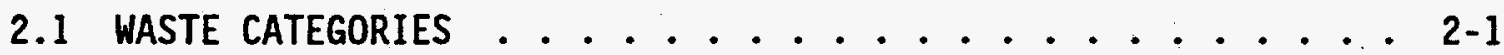

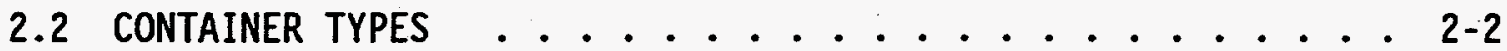

2.3 FORECASTED CONTAINER TYPES AND WASTE CATEGORIES $\ldots \ldots$

2.3.1 Volumes by Container Type . . . . . . . . 2-4

2.3.2 Volumes by Waste Category .......... 2-5

2.3.3 Major LLMW and TRU/TRUM Waste Generators . . . . 2-5

3.0 LOW-LEVEL MIXED WASTE ................... 3-1

3.1 LLMW VOLUME ................... . . 3-1

3.2 LLMW CATEGORIES BY CONTAINER TYPE ............ .2

3.2.1 Contact-Handled Low-Level Mixed Waste . . . . . 3-2

3.2.2 Remote-Handled Low-Level Mixed Waste . . . . . 3-5

4.0 TRANSURANIC AND TRANSURANIC MIXED WASTE ........... . . . 4-1

4.1 TRU/TRUM WASTE VOLUME ................. 4-1

4.2 TRU/TRUM WASTE CATEGORIES BY CONTAINER TYPE $\ldots \ldots$. .

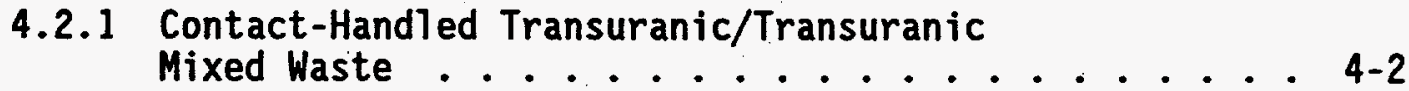

4.2.2 Remote-Handled Transuranic/Transuranic
Mixed Waste ..................... 4-4

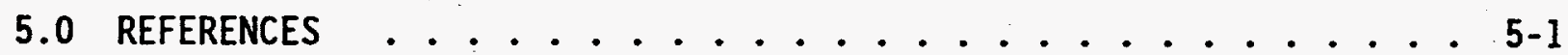

APPENDIX A - LOW-LEVEL WASTE VOLUMES AND CONTAINER TYPES . . . . . A-1

APPENDIX B - D\&D REFERENCES . . . . . . . . . . . . B-1

APPENDIX C - ANNUAL CONTAINER TYPE VOLUMES BY WASTE CLASS . . . . . c-1

APPENDIX D - ANNUAL WASTE CLASS VOLUMES BY CONTAINER TYPES . . . . D-1 
WHC-EP-0803

APPENDIX E - WASTE GENERATOR CONTAINER TYPE VOLUMES BY WASTE CLASS - • E-1 APPENDIX F - FY-1993 WASTE GENERATOR ABBREVIATION LIST . . • . • . . . F-1 


\section{LIST OF FIGURES}

2-1 LLMW and TRU/TRUM Waste Volumes by Container Type ...... 2-4

2-2 Annual Volumes of LLMW and TRU/TRUM Waste by Container Type . . 2-5

2-3 LLMW and TRU/TRUM Waste Volumes by Waste Category . . . . . 2-6

2-4 Annual Volume of LLMW and TRU/TRUM Waste by Waste Category . . 2-6

2-5 Major LLMW and TRU/TRUM Waste Generators ... . . . . . 2-7

3-1 Total Volume of LLMW by Waste Category . . . . . . . . . . 3-1

3-2 Major LLMW Generators ................ 3-2

3-3 CH_LLMW Volumes by Container Type ........... 3-3

3-4 Annual Volume of CH_LLMW by Container Type ......... 3-3

3-5 RH_LLMW Volumes by Container Type ........... 3-6

3-6 Annual Volume of RH_LLMW by Container Type . . . . . . . 3-6

4-1 Total Volume of TRU/TRUM Waste by Waste Category . . . . . 4-1

4-2 Major TRU/TRUM Waste Generators ........... 4-2

4-3 CH_TRU/TRUM Waste Volumes by Container Type ........ 4-3

4-4 Annual Volume of $\mathrm{CH}_{-}$TRU/TRUM Waste by Container Type ..... 4-3

4-5 RH_TRU/TRUM Waste Volumes by Container Type . . . . . . . 4-5

4-6 Annual Volume of RH_TRU/TRUM Waste by Container Type . . . . 4-5 
WHC-EP-0803

\section{LIST OF TABLES}

2-1 Volumes and Waste Streams for Waste Containers . . . . . . . 2-3

3-1 CH_LLMW Generators by Container Type . . . . . . . . . . 3-4

3-2 RH_LLMW Generators by Container Type . . . . . . . . . . . 3-7

4-1 CH_TRU/TRUM Waste Generators by Container Type . . . . . . . 4-4

4-2 RH_TRU/TRUM Waste Generators by Container Type . . . . . . . 4-6 


\subsection{INTRODUCTION}

This document, prepared by Pacific Northwest Laboratory (PNL) under the direction of Westinghouse Hanford Company (WHC), provides a description of the containers expected to be used for shipping low-level mixed solid waste (LLMW) and transuranic/transuranic mixed (TRU/TRUM) solid waste to the Hanford Solid Waste Operations Complex (SWOC) ${ }^{1}$ over the next 30 years. This solid waste will be generated from ongoing operations, maintenance activities, deactivation activities, decontamination and decommissioning (D\&D) of facilities, and environmental restoration (ER) activities.

For the past four years, the annual solid waste volume forecast (for the next $30^{\circ}$ years) has been collected from all onsite and offsite generators that are planning to ship waste to the Hanford Site. The generators provide details about the amount of waste to be generated each year, the containers that will be used to ship the waste, and specific waste characteristics that help determine the proper treatment, storage, and disposal (TSD) requirements. This document, which is based primarily upon the 1993 Solid Waste Forecast, provides information on the containers intended to be used to ship waste to the Hanford Site. Volume information on the annual LLMW and TRU/TRUM waste is reported in WHC-EP-0768, Solid Waste 30-Year Volume Summary. The physical and hazardous characteristics of the forecasted waste volumes are reported in WHC-EP-0802, 1994 Solid Waste Forecast Summary: Waste Characteristics and Treatability Groups.

This document is intended to be used in conjunction with other solid waste planning documents as a reference for short-and long-term planning of the Hanford TSD activities over the next several decades. Knowledge of the number and types of shipping containers to be used by onsite and offsite waste generators aids in planning TSD facility capacities and container handling requirements. This document will describe the types of containers that will be used for packaging LLMW and TRU/TRUM waste. Containers used for Tow-level waste (LLW) will be described in an appendix, because LLW requires minimal treatment and storage prior to onsite disposal in the LLW burial grounds. The major waste generators for each waste category and container type will also be discussed.

Because this document must serve several audiences, the information will be described at various levels of detail. Section 2.0 of this report provides an overview of the overall volume by container type and waste category. Brief definitions of the container types and waste categories are also provided. Sections 3.0 and 4.0 discuss the volumes by container type for LLMW and TRU/ TRUM, respectively: These sections are broken down by waste category, and the associated waste containers are described. In addition, the main waste generators for each waste category and container type will be discussed. Appen$\operatorname{dix} A$ describes the LLW volumes by container type, and Appendix B provides a

1 The SWOC is defined for this report to include the existing Central Waste Complex and future facilities as identified in the Solid Waste Technical Baseline Description, WHC-SD-WM-RTP-000, Rev. 0. 
description of the assumptions used for D\&D waste generators. Appendix C provides volume information by container type for each waste class, while Appendix $D$ describes the waste class volumes by container type. Appendix $E$ describes the waste volume by container type for each onsite and offsite waste generator. 
WHC-EP-0803

\subsection{OVERVIEW}

This section provides an overview of the LLMW and TRU/TRUM solid waste volumes by waste category and container type that are expected to be generated by onsite and offsite waste generators in the next 30 years. Brief descriptions of the waste categories and container types are provided as well. Lastly, the major waste generators of the LLMW and TRU/TRUM waste volumes are discussed. The purpose of the information presented in this overview is to provide a general description of the volumes by container type for short- and long-term planning of Hanford's solid waste management facilities in terms of TSD and handiing requirements.

\subsection{WASTE CATEGORIES}

The waste volumes and container types are described in this document by waste category. The waste is divided into four broad categories based upon concentrations of radionuclides and surface dose rates of the waste package. For the purposes of this document, the contact-handled and remote-handled categories will be combined for each waste classification to form the basis of each section. The categories are briefly described below:

- Contact-handled low-level mixed waste (CH LLMW): This waste has a dose rate less than or equal to $200 \mathrm{mrem} / \overline{\mathrm{h}}$ at contact with the waste container. The waste contains radioactivity that is not classified as transuranic waste or spent nuclear fuel; however, the waste does contain dangerous constituents as identified by Washington Administrative Code (WAC) 173-303 (Ecology 1993). The concentration of transuranic radionuclides is less than or equal to $100 \mathrm{nCi} / \mathrm{g}$ of the waste matrix.

- Remote-handled low-level mixed waste (RH LLMW): This waste has a dose rate greater than $200 \mathrm{mrem} / \mathrm{h}$ at contact with the waste container. The waste contains radioactivity that is not classified as transuranic waste or spent nuclear fuel; however, the waste does contain dangerous constituents as identified by WAC 173-303. The concentration of transuranic radionuclides is less than or equal to $100 \mathrm{nCi} / \mathrm{g}$ of the waste matrix.

- Contact-handled transuranic/transuranic mixed waste (CH_TRU/TRUM): This waste has a dose rate less than or equal to $200 \mathrm{mrem} / \mathrm{h}$ at contact with the waste container. At the time of assay, this waste contains more than $100 \mathrm{nCi} / \mathrm{g}$ of alpha-emitting isotopes with atomic numbers greater than 92 and half-lives greater than 20 years. TRUM waste is TRU waste that is also dangerous waste as defined in WAC 173-303. 
WHC-EP-0803

- Remote-handled transuranic/transuranic mixed waste (RH_TRU/TRUM): This waste has a dose rate greater than $200 \mathrm{mrem} / \mathrm{h}$ at contact with the waste container. At the time of assay, this waste contains more than $100 \mathrm{nCi} / \mathrm{g}$ of alpha-emitting isotopes with atomic numbers greater than 92 and half-lives greater than 20 years. TRUM waste is TRU waste that is also dangerous waste as defined in WAC 173-303.

\subsection{CONTAINER TYPES}

In the 1993 Solid Waste Forecasts, 16 primary container types were identified to be used to ship waste to the Hanford Site over the next 30 years. The majority of the waste will be shipped in six of these 16 container types: $4^{\prime} \times 4^{\prime} \times 8^{\prime}$ boxes, unknown boxes, 55-gallon drums, other drums, long-length equipment containers, and casks. Table 2-1 has been provided to further describe the container types by external and internal dimensions and the waste streams shipped in each container type. References are provided in Table 2-1 for those seeking more detailed information about the containers. The following is a brief description of each major container type.

- $4^{\prime} \times 4^{\prime} \times 8^{\prime}$ boxes: This shipping container is typically either plywood or metal with dimensions of 4 feet wide, 4 feet deep, and 8 feet long. The external volume is 128 cubic feet without skids attached; the external volume is 143 cubic feet if skids are attached. The internal volume is 120 cubic feet for the metal box (WHC 1990).

- Unknown boxes: This container type is an unknown shipping container with unknown dimensions. This category is selected by those waste generators that cannot forecast the exact box size to be used for waste shipments over the next 30-year period.

- 55-gallon drums: This shipping container is typically 2 feet in diameter and 2.9 feet long with an external volume of 9.2 cubic feet. The internal volume will vary depending on the type of waste to be shipped. Table 2-1 provides the varying internal volume options.

- Other drums: This container type category includes all other drums besides the 55- and 30-gallon drums. The 30-gallon drum is a separate option that is not a major container type. Dimensions, external volume, and internal volumes of drums in the "other" category vary depending on the size of the drum.

- Long-length equipment containers (LEC): There are six different LECs with varying dimensions that are provided in Table $2-1$. The, primary use of this container is for contaminated long-length equipment from the tank farms. 
Table 2-1. Volumes and Waste Streams for Waste Containers.

\begin{tabular}{|c|c|c|c|c|}
\hline CONTAINER & EXTERNAL VOLUME $\mathrm{FT}^{3}$ & INTERNAL VOLUME FT ${ }^{3}$ & REFERENCES & WASTE STREAMS \\
\hline \multicolumn{5}{|c|}{ Boxes } \\
\hline LSA Plywood $4^{\prime} \times 4^{\prime} \times 8^{\prime}$ without skids & 128.0 & & WHC-SP-0364 & $\begin{array}{l}\text { LLW, LLMW, } \\
\text { TRUTTRUM }\end{array}$ \\
\hline LSA Plywood $4^{\prime} \times 4^{\prime} \times 8^{\prime}$ with skids & 143.0 & & $\begin{array}{c}\text { WHC-SD-WM-SARP-003 } \\
\text { Rev } 0\end{array}$ & $\begin{array}{c}\text { LLW, } \\
\text { LLMW,TRU/TRUM }\end{array}$ \\
\hline Metal $4^{\prime} \times 4^{\prime} \times 8^{\prime}$ & 128.0 & 120.0 & WHC-SP-0364 & $\begin{array}{l}\text { LLW, LLMW, } \\
\text { TRU/TRUM }\end{array}$ \\
\hline SWB & 73.4 & 68.7 & WHC-SD-TP-SARP-004 & TRU/TRUM \\
\hline B-25 & 103.2 & 90.1 & WHC-SP-1070/CPC & LLMW, LLW \\
\hline \multicolumn{5}{|c|}{ Drums } \\
\hline 55 gallon, Non TRU & 9.2 & 7.4 & WHC-EP-0558 & LLW, LLMW \\
\hline 55 gallon, TRU & 9.2 & 7.4 & WHC-EP-0558 & TRU/TRUM \\
\hline 55 - gallon, TRU Organic & 9.2 & 2.4 & WHC-SP-0364 & TRU/TRUM - organic \\
\hline 55 - gallon, Internally Shielded & 9.2 & 1.9 & WHC-SP-0364 & RH \\
\hline 55 - gallon, TRU, Lead Lined & 9.2 & 0.8 & WHC-SP-0364 & TRU/TRUM - lead-line \\
\hline 85 - gallon & 12.1 & 12.0 & HS-V-P-0010 REV C & \\
\hline \multicolumn{5}{|c|}{ Long Length Equipment Containers } \\
\hline LEC-1 $\left(3.67^{\prime} \times 4^{\prime} \times 36.33^{\prime}\right)$ & 533.2 & 238.9 & WHC-SD-WM-ES-265 & LLMW, TRUM \\
\hline LEC.2 $\left(3.67^{\prime} \times 4^{\prime} \times 51.33^{\prime}\right)$ & 753.5 & 347.3 & WHC-SD-WM-ES-265 & LLMW, TRUM \\
\hline LEC-3 $\left(3.67^{\prime} \times 4^{\prime} \times 70.33^{\prime}\right)$ & $1,032.4$ & 469.3 & WHC-SD-WM-ES-265 & LLMW, TRUM \\
\hline LEC. $4\left(4.92^{\prime} \times 5.5^{\prime} \times 70.33^{\prime}\right)$ & $1,903.1$ & 992.1 & WHC-SD-WM-ES-265 & LLMW, TRUM \\
\hline LEC-5 $\left(6.67^{\prime} \times 7.17^{\prime} \times 52.5^{\prime}\right)$ & $2,510.8$ & $1,190.1$ & WHC-SD-WM-ES-265 & LLMW, TRUM \\
\hline LEC-6 $\left(6.67^{\prime} \times 7.17^{\prime} \times 70.5^{\prime}\right)$ & $3,371.6$ & $1,608.1$ & WHC-SD-WM-ES-26̣5 & LLMW, TAUM \\
\hline
\end{tabular}


- Casks: This container type would typically be 9.5 feet long and 9.1 feet high. The external volume is 630 cubic feet; it weighs about 40 tons. This container type is mainly planned to contain RH_TRUM from the tank farm low-level waste pretreatment facility.

\subsection{FORECASTED CONTAINER TYPES AND WASTE CATEGORIES}

The following describes the LLMW and TRU/TRUM waste volumes by container type and waste category. The major waste generators of LLMW and TRU/TRUM waste are also provided. This information is useful in short-and long-term planning of Hanford's solid waste management facilities in terms of TSD and handling requirements.

\subsubsection{Volumes by Container Type}

The LLMW and TRU/TRUM waste container types forecasted for the next 30 years are displayed in Figure 2-1. As shown in the figure, the total volume of waste to be shipped is approximately $307,150 \mathrm{~m}^{3}$. The main container type is 55 -gallon drums that will contain $36 \%$ of the waste. LECs will contain $32 \%$; unknown boxes will contain $15 \%$; casks will contain $7 \%$; $4^{\prime} \times 4^{\prime} \times 8^{\prime}$ boxes will contain 6\%; and all other containers will contain $4 \%$ of the waste.

Figure 2-2 displays the LLMW and TRU/TRUM annual waste volumes by container type. The figure shows a peak from 2004 through 2006 that represents the tank farm low-level waste pretreatment facility shipping schedule. The other significant peak occurs from 2013 through 2017 and represents the shipping scheduled for the assumed decontamination and decommissioning (D\&D)

Figure 2-1. LLMW and TRU/TRUM Waste Volumes by Container Type.

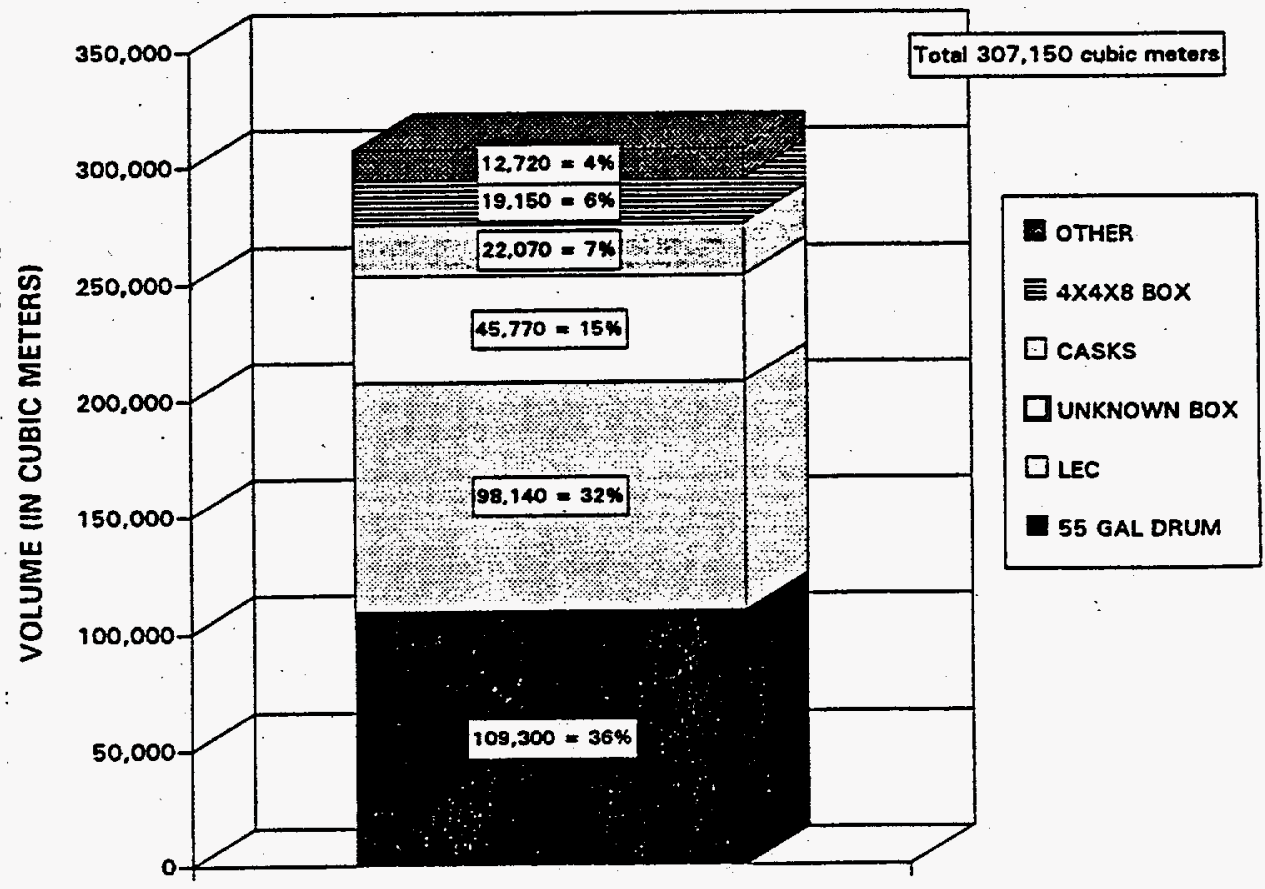


Figure 2-2. Annual Volume of LLMW and TRU/TRUM Waste by Container Type.

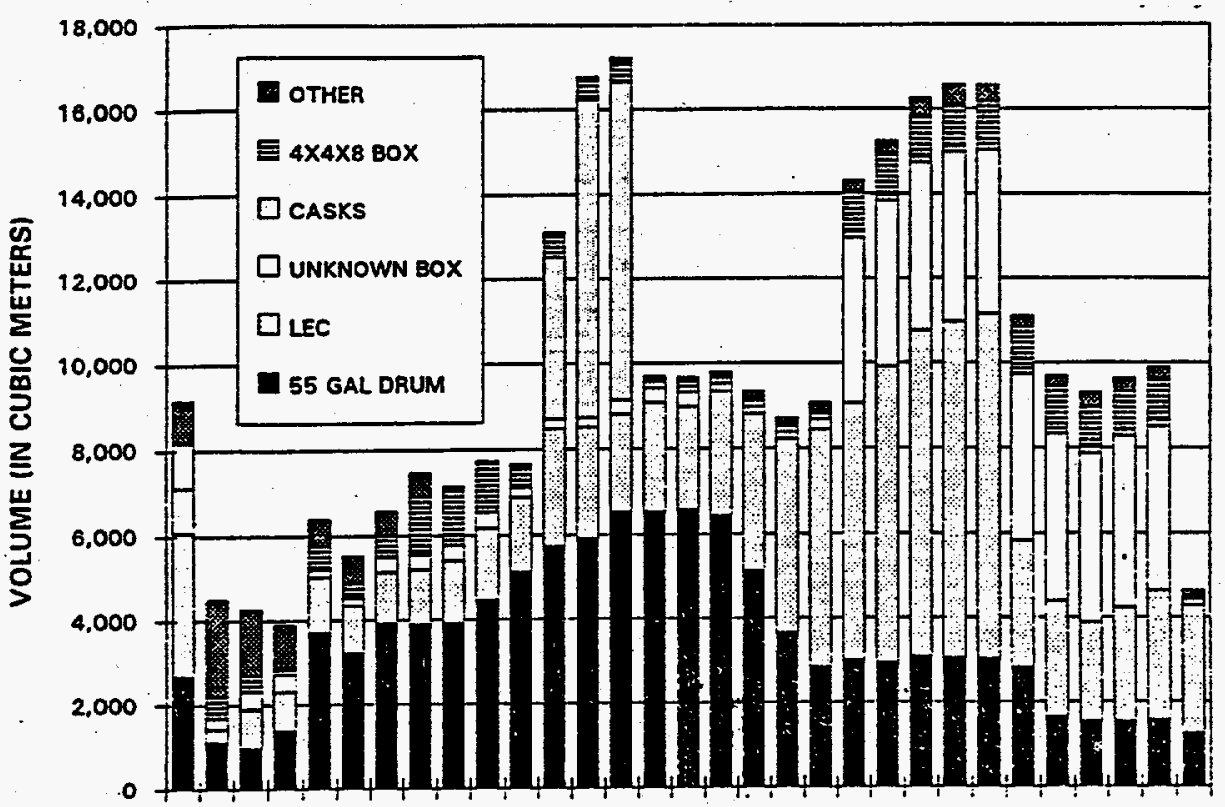

HELD 199519971999200120032005200720092011201320152017201920212023

YEARS

of the Plutonium Finishing Plant and the retrieval of the Long-Length Equipment. The dates for shipment of D\&D waste from the PTutonium Finishing Plant are unknown, and an assumption was made that, until further planning has been completed, the waste would be shipped from 2013 through 2022. Detailed information on the assumptions made for D\&D generators are discussed in Appendix B.

\subsubsection{Volumes by Waste Category}

The volume of LLMW and TRU/TRUM waste is represented by waste category in Figure 2-3. The majority of the waste is CH LLMW and RH LLMW which constitutes $72 \%$ of the waste. CH TRU/TRUM waste and RH TRU/TRUM waste make up the remaining $28 \%$. Figure $2-4^{-}$displays the annual volumes by waste category. The two peaks shown in the figure are identical to those peaks in Figure 2-2 since the volumes are the same but broken out by waste category instead of container type. The first peak mainly consists of CH_LLMW and RH_TRU/TRUM waste, while the second peak shows primarily the generation of RH_LLMW.

\subsubsection{Major LLMW and TRU/TRUM Waste Generators}

The major waste generators of LLMW and TRU/TRUM waste are displayed in Figure 2-5. The largest proportion of waste is generated by the retrieval of Long-Length Equipment, which comprises $32 \%$. Past Practice Remediation generates 18\%; D\&D of the P7utonium Finishing Plant generates $8 \%$; Portsmouth Gaseous Diffusion Plant generates 7\%; the tank farm low-level waste pretreatment facility generates $5 \%$; and the remaining $30 \%$ is generated by a number of 
Figure 2-3. LLMW and TRU/TRUM Waste Volumes by Waste Category.

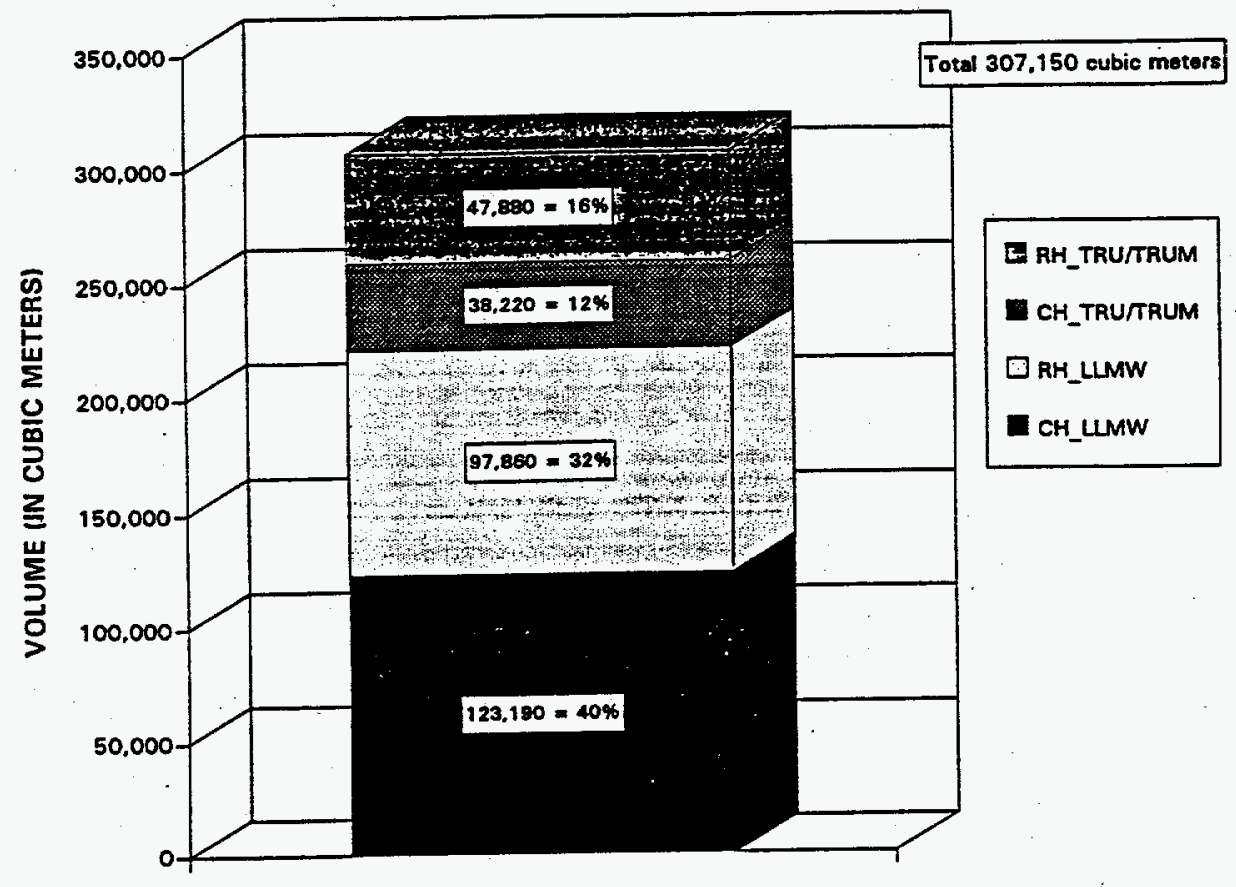

Figure 2-4. Annual Volume of LLMW and TRU/TRUM Waste by Waste Category.

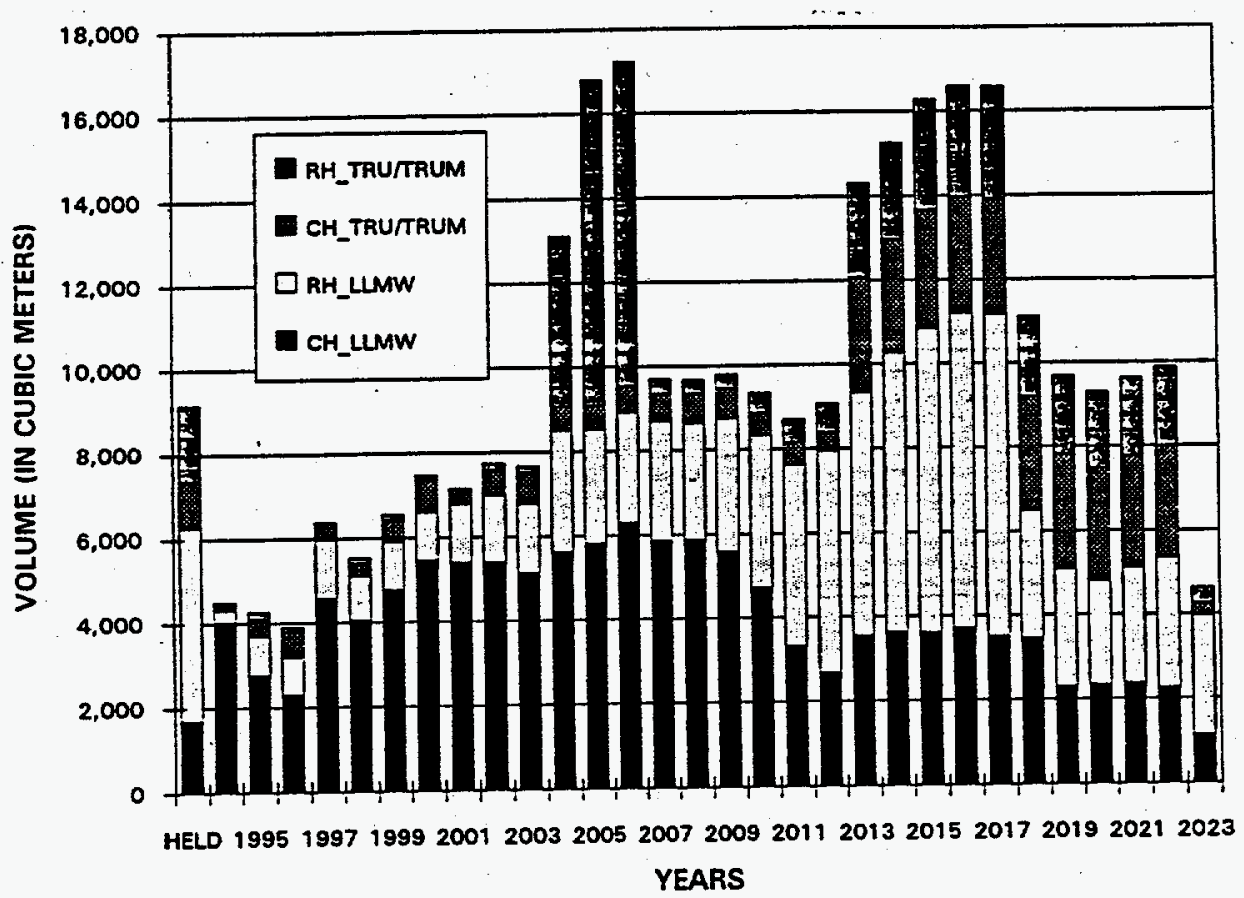


Figure 2-5. Major LLMW and TRU/TRUM Waste Generators.

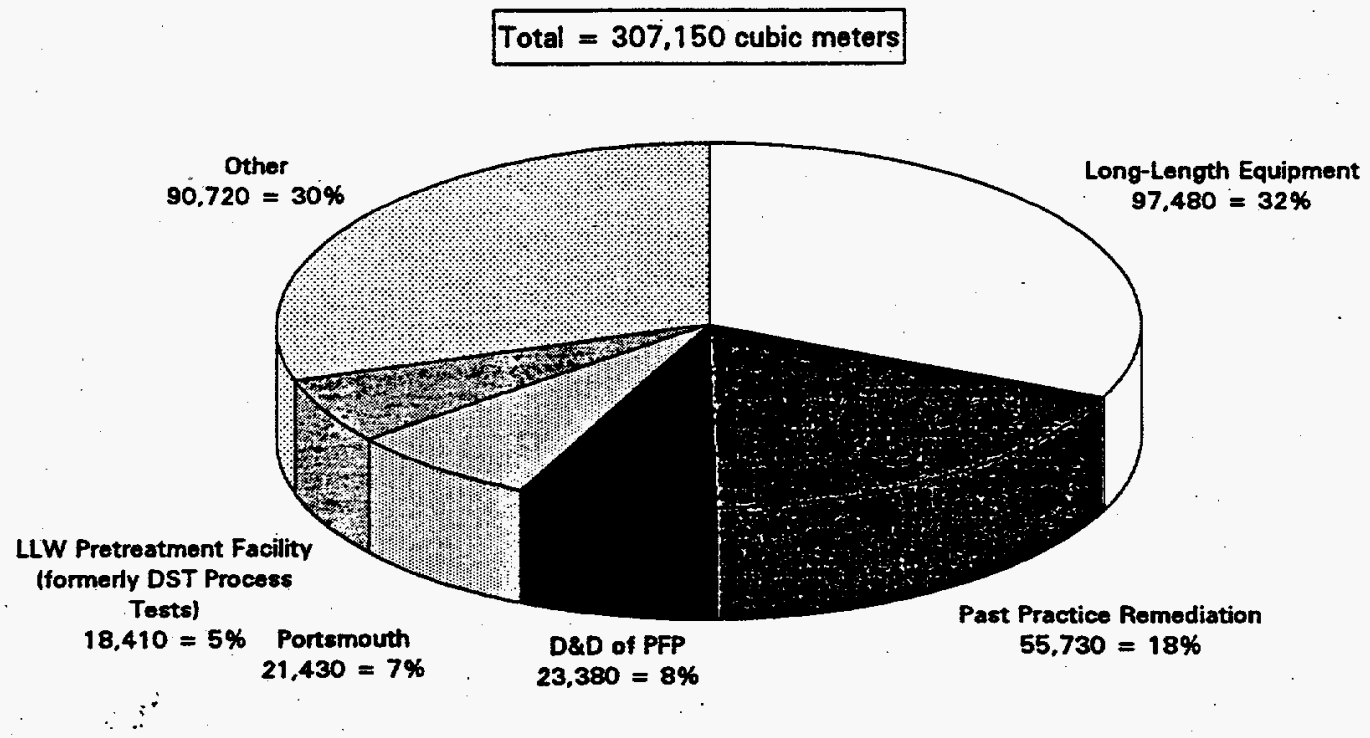

other waste generators. The following is a brief description of each of these major waste generators. All assumptions associated with D\&D generators are further described in Appendix B.

- Long-Length Equipment: During tank farm cleanup, current planning is to remove the long-length pieces of equipment from the tanks and send this equipment to the SWOC for TSD. The long-1ength equipment is equipment that has been installed in the tanks and is greater than 12 feet in length, with some pieces in excess of 60 feet. Because of the unusual configuration of these wastes, special storage and handling requirements will be necessary. In addition to the equipment currently in the tanks, estimates have been included for pumps and other miscellaneous equipment that will be used for retrieval of tank waste. The retrieval pumps and equipment are also expected to be sent to the SWOC for processing and will have many of the same storage and handling requirements as the longlength equipment.

- Past Practice Remediation: The Environmental Remediation Program is responsible for the remediation of Hanford's past practice sites. It is assumed that the Solid Waste Program may be responsible for $100 \%$ of the TRU/TRUM waste generated from these sites, as we 17 as for $10 \%$ of the LLMW.

- D\&D of the Plutonium Finishing Plant: The solid waste generated during the D\&D of this facility includes volume estimates from the $236 Z$ Building and its associated buildings $241 Z, 242 Z$, and $2345 Z$. The solid waste material includes such items as gloveboxes, pedestal storage, ventilation systems, pencil tanks, and 
ventilation fans. The shipping schedule for this waste generator is unknown and has been assumed to be from 2013 through 2022 unti1 further planning is completed.

- Portsmouth Gaseous Diffusion Plant: The waste volumes associated with this waste generator are primarily existing waste volumes with a few environmental restoration projects. The operational waste was not included in the forecast, because this generator has indicated that the United States Enrichment Corporation (USEC) took over operations on July 1, 1993. Hanford has not accepted waste from Portsmouth for the past three years; if this trend continues, it is likely the volumes associated with Portsmouth will not be sent to Hanford in the future.

- Tank Farm Low-Level Waste Pretreatment Facility: The waste volumes associated with this waste generator are based on a proposed project to pretreat tank waste supernatant for final low-level waste treatment. Although the original treatment facility (LLW Grout facility) for which this project was planned has been terminated, it is assumed that some sort of pretreatment will still be required prior to final stabilization of the tank waste. Therefore, the volumes estimated for the original pretreatment facility have been included in this report, but the 1993 forecast volumes have been delayed eight years to correspond to the startup of the low-level waste treatment facility established by the revised TriParty Agreement. 


\subsection{LOW-LEVEL MIXED WASTE}

This section provides waste volumes by container type and waste category for LLMW. The major waste generators of LLMW are also described. LLMW will be treated and stored at the SWOC and shipped to the onsite mixed waste trench for disposal.

\subsection{LLMW VOLUME}

The total amount of LLMW to be shipped to the SWOC in the next 30 years is approximately $221,050 \mathrm{~m}^{3}$. Of this waste, $56 \%$ is $\mathrm{CH}$ LLMW, while the remaining $44 \%$ is RH_LLMW as depicted in Figure 3-1. Figure $\overline{3}-2$ displays the major waste generators of LLMW. Forty percent is generated by Long-Length Equipment; Past Practice Remediation generates 23\%; Portsmouth generates 10\%; Tank Farm Restoration and Buried Equipment each generate $3 \%$; and the remaining $21 \%$ is generated by other miscellaneous waste generators. These waste generators have been described in Section 2.0 with the exception of Tank Farm Restoration and Buried Equipment. The following will briefly describe these two generators.

- Tank Farm Restoration: This Major System Acquisition project includes several sub-projects: Double-Shell Tank Ventilation Upgrades, Tank Farm Integrated Instrumentation Upgrades, Waste Transfer System Upgrades, Radiation Zone Lighting Upgrades, Tank

Figure 3-1. Total Volume of LLMW by Waste Category.

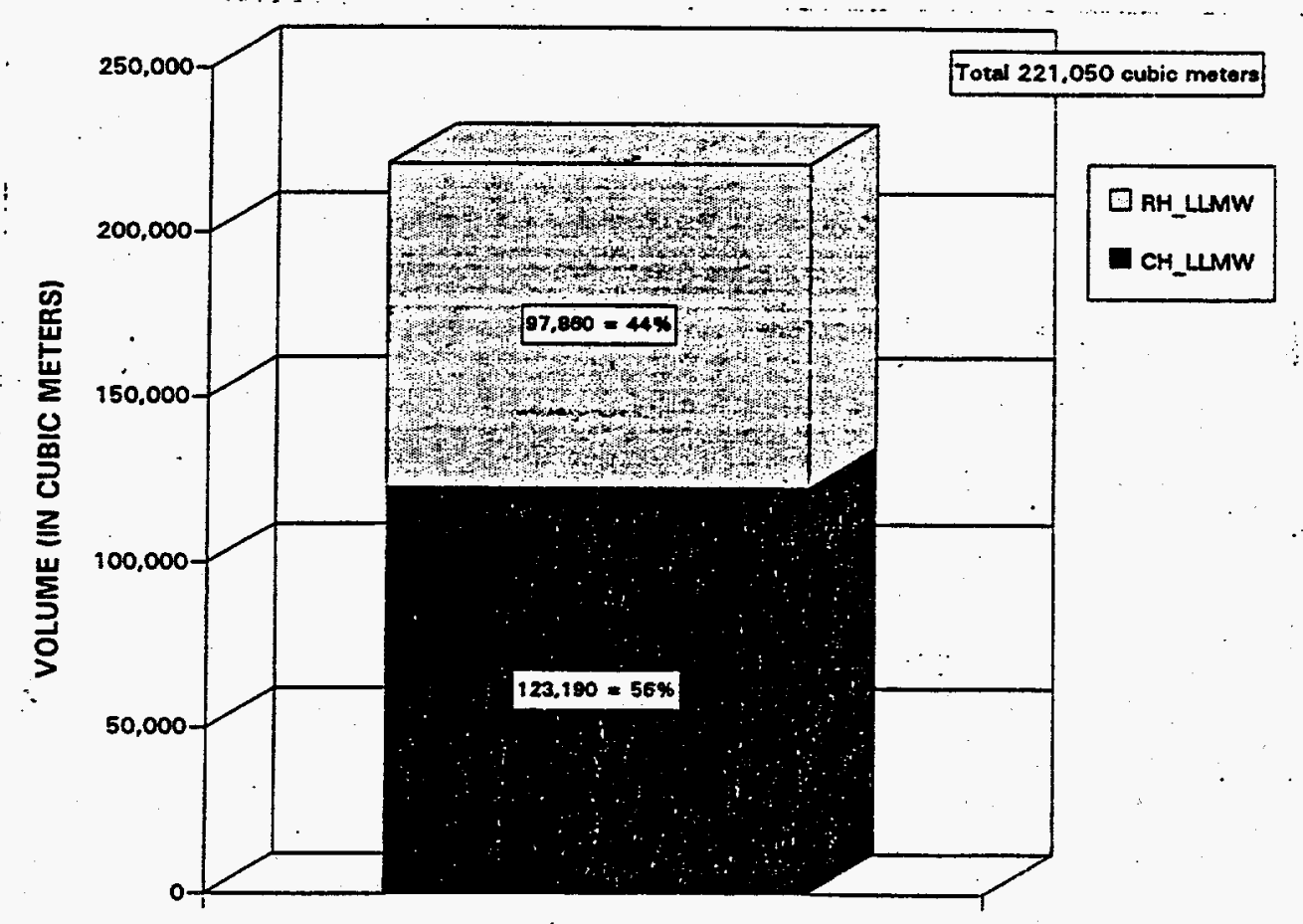


Figure 3-2. Major LLMW Generators.

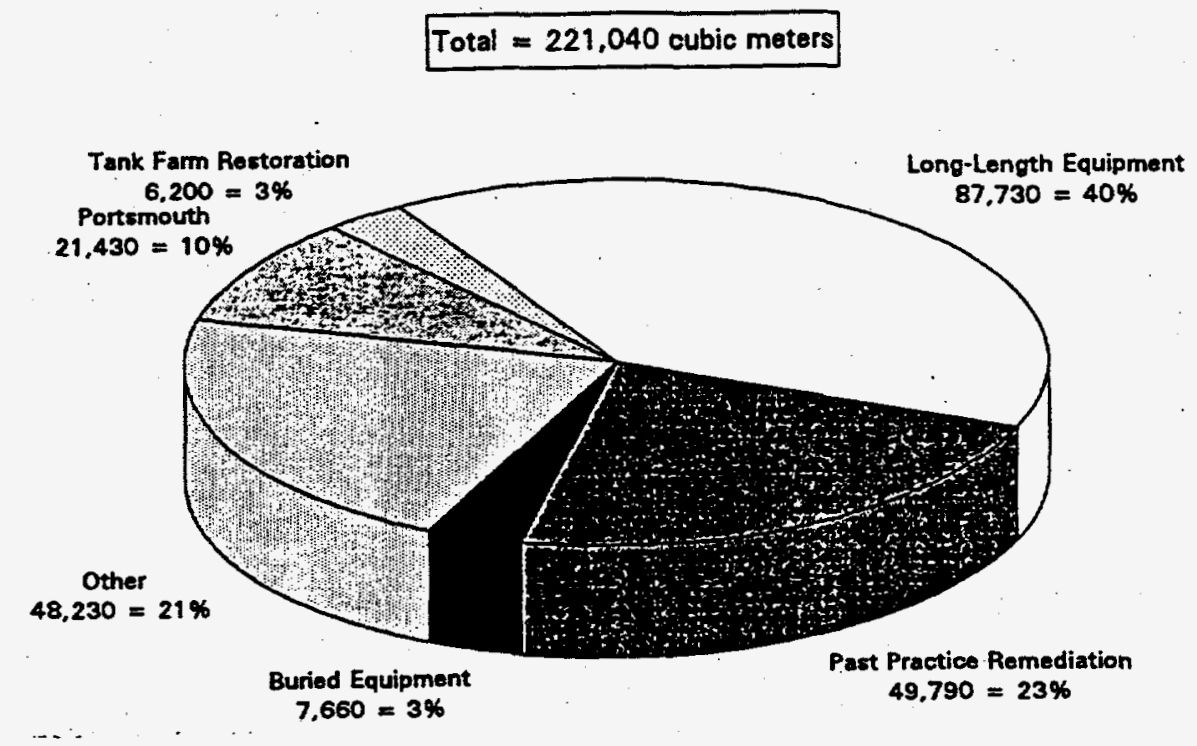

Farm Electrical Upgrades, Single-She11 Tank Ventilation Upgrades, and Tank Farm Centralized Control and Maintenance Facilities. Solid waste generated from these sub-projects will include miscellaneous construction debris, contaminated soils, and demolished tank farm equipment.

- Buried Equipment: The responsibility of this waste generator is to dispose of general-purpose coded equipment, such as vehicles and mobile construction units used in the tank farms. The waste volumes are based on existing waste that has not been shipped since 1992. The existing waste is currently located with the respective waste generators.

\subsection{LLMW CATEGORIES BY CONTAINER TYPE}

A brief description of each waste category of LLMW by container type is included below. The total volumes are discussed, as are the annual volumes in terms of the main container types forecasted for shipment to the SWOC. The waste generators for each waste category are al so described.

\subsubsection{Contact-Handled Low-Level Mixed Waste}

The total amount of $\mathrm{CH}_{\text {LLMW }}$ to be shipped to the SWOC in the next 30 years is approximately $123, \overline{1} 90 \mathrm{~m}^{3}$. Figure 3-3 displays the total volume of CH_LLMW by container type. As depicted in the figure, $72 \%$ wi 17 be shipped in 55 -gallon drums; $12 \%$ in $4^{\prime} \times 4^{\prime} \times 8^{\prime}$ boxes; $9 \%$ in unknown boxes; and the remaining $7 \%$ in other miscellaneous containers.

Figure 3-4 displays the annual volumes of CH LLMW by container type. As depicted in the figure, there is a fairly constant amount of waste until 2012, when there appears to be a slight decrease in waste volumes through 2023 . 
Figure 3-3. CH_LLMW Volumes by Container Type.

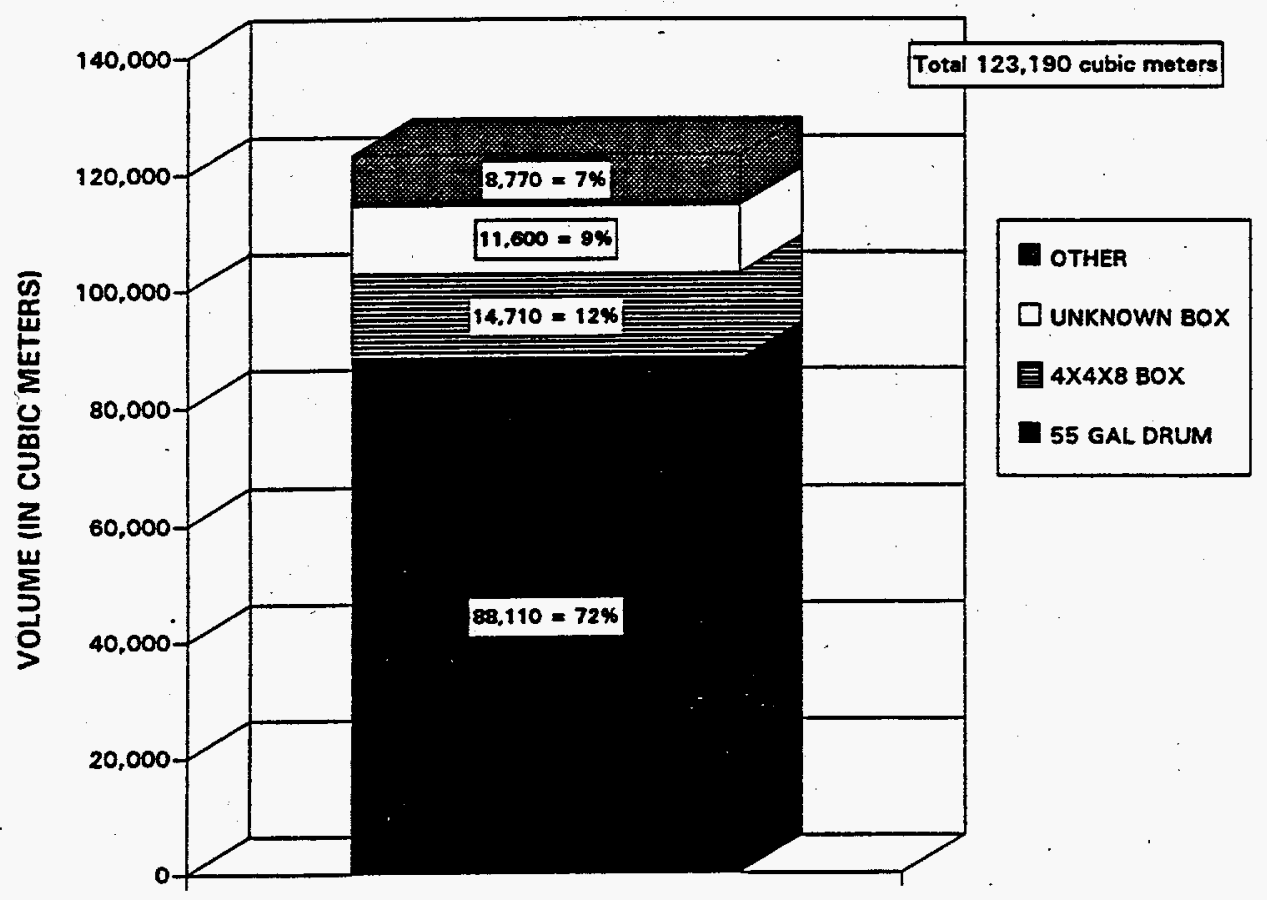

Figure 3-4. Annual Volume of CH_LLMW by Container Type.

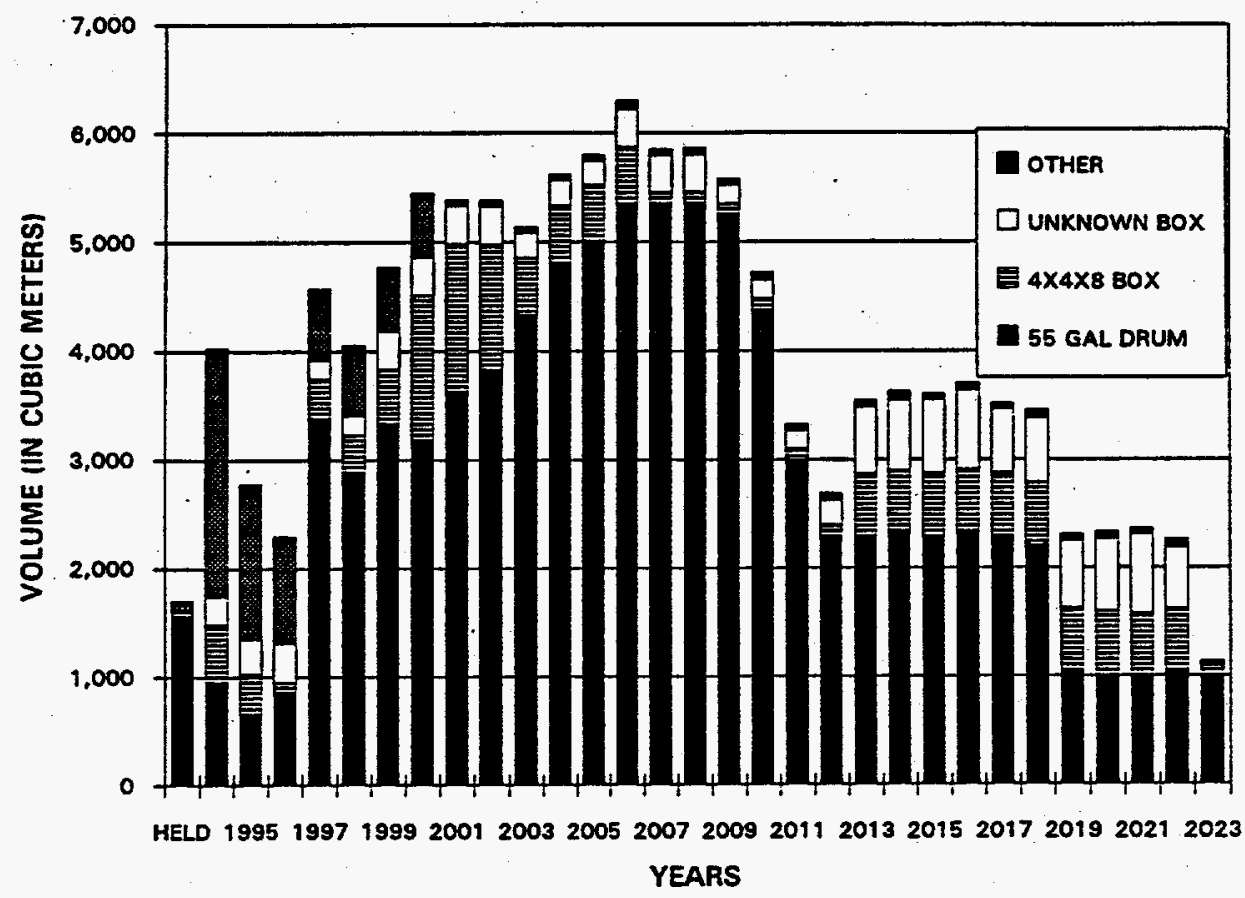


This is reflective of the shipping schedule of Past Practice Remediation, which is planning to ship the majority of its waste from 1997 through 2011 in 55-gallon drums.

The CH LLMW volumes for each waste generator are displayed by main container type in Table 3-1. Past Practice Remediation generates $40 \%$ of the total waste, Portsmouth generates $17 \%$, and Buried Equipment generates $6 \%$.

Table 3-1. CH LLMW Generators By Container Type.

\begin{tabular}{|c|c|c|c|c|c|}
\hline WASTE GENERATOR & $\begin{array}{l}55 \text { GAL } \\
\text { DRUMM }\end{array}$ & $\begin{array}{c}4^{1} \times 41 \times 81 \\
80 \times\end{array}$ & $\begin{array}{c}\text { UNKNONN } \\
\text { BOX }\end{array}$ & OTHER & TOTAL \\
\hline Past Practice Remediation & 49,793 & 0 & 0 & 0 & 49,793 \\
\hline Portsmouth & 17,471 & 0 & 0 & 3,962 & 21,433 \\
\hline Buried Equipment & 0 & 0 & 7,663 & 0 & 7,663 \\
\hline Tank Farm Restoration & 0 & 6,197 & 0 & 0 & 6,197 \\
\hline Purex $242 \mathrm{~A}$ Condensate Ireatment & 5,385 & 210 & 0 & 167 & 5,762 \\
\hline T-Plant Bldg. - DED & 0 & 2,719 & 2,719 & 0 & 5,438 \\
\hline Single Shell Tank Farms & 1,132 & 2,368 & 0 & 595 & 4,095 \\
\hline Argonne Nat. Lab.-East & 441 & 0 & 0 & 2,519 & 2,960 \\
\hline Paducah Energy Systems & 2,620 & 0 & 0 & 308 & 2,928 \\
\hline $\begin{array}{l}\text { Environmental Restoration Operations - } \\
\text { D\&D of Surplus Facilities }\end{array}$ & 2,848 & 0 & $\mathbf{0}$ & $\mathbf{0}$ & 2,848 \\
\hline CP 222-S Laboratory & 1,582 & 205 & $\underline{0}$ & 0 & 1,787 \\
\hline Sec. Waste from Long Length Equip. & 1,634 & 0 & 0 & 0 & 1,634 \\
\hline Purex-242A Effluent Treatment - D\&D & 0 & 1,599 & 0 & 0 & 1,599 \\
\hline $\begin{array}{l}\text { LLW. Treatment Facility (formerly DWM } \\
\text { Grout Facility) }\end{array}$ & 991 & 0 & 0 & 286 & 1,277 \\
\hline PD Waste Vitrification Project & 906 & 124 & 0 & 0 & 1,030 \\
\hline Tank Farms Backlog Waste & 429 & 477 & 0 & 25 & 931 \\
\hline Knolls Atomic Power Shipyards & 0 & 0 & 0 & 657 & 657 \\
\hline Laurence Livermore NatL Lab & 629 & 0 & $\underline{0}$ & 0 & 629 \\
\hline T-Plant Bldg. $2706 / 221$ & 594 & 0 & 0 & 0 & 594 \\
\hline Pacific Northwest Laboratory & 235 & 0 & 0 & 198 & 433 \\
\hline PO Haste Vitrification Project - D\&D & 0 & 368 & 0 & 0 & 368 \\
\hline A Evaporator - D\&D & 0 & 33 & 299 & 0 & 326 \\
\hline S Evaporator - D\&D & 0 & 33 & 293 & 0 & 326 \\
\hline SST Retrieval (149 tanks) & 293 & 0 & 0 & 0 & 293 \\
\hline Lawrence Berkeley Lab & 287 & 0 & 0 & 0 & 287 \\
\hline DLM B Plant \& UESF - D\&D & 0 & 0 & $2 \pi$ & 0 & 277 \\
\hline Ames Laboratory-Ames, Iowa & 1 & 236 & 0 & 0 & 237 \\
\hline CP Purex \& y03-224U - D\&D & 0 & 0 & 236 & 0 & 236 \\
\hline CP Plutonium Finishing Plant & 219 & 0 & 0 & $\mathbf{0}$ & 219 \\
\hline U320 Tank 241 sluicing & 21 & 119 & 0 & 0 & 140 \\
\hline Brookhaven & 136 & 0 & 0 & 0 & 136 \\
\hline Paducah Utility Services & 84 & 0 & 0 & 0 & 84 \\
\hline
\end{tabular}


WHC-EP-0803

Table 3-1. (contd).

\begin{tabular}{|c|c|c|c|c|c|}
\hline WASTE GENERATOR & $\begin{array}{c}55 \mathrm{GAL} \\
\text { DRUM }\end{array}$ & $4^{\circ} \times 4^{\prime} \times 8^{\prime}$ & $\begin{array}{l}\text { UNKNOWN } \\
\text { BOX }\end{array}$ & OTHER & TOTAL \\
\hline T Evaporator - D\&D & 0 & 7 & 57 & 0 & 64 \\
\hline FERMI Nat. Accelerator Lab. & 63 & 0 & 0 & 0 & 63 \\
\hline DRD 100 Area & 58 & 0 & 0 & 2 & 60 \\
\hline Plasma Physics Laboratory & 57 & 0 & 0 & $\mathbf{0}$ & 57 \\
\hline Battelle Columbus Operations & 47 & 0 & 0 & 0 & 47 \\
\hline CP 222-S Lab - DED & 0 & 0 & 41 & 0 & 41 \\
\hline Bettis Atomic Power Laboratory & 31 & 0 & 0 & 8 & 38 \\
\hline DWM Low Level Burial Grounds & 0 & 0 & 0 & 34 & 34 \\
\hline Environmental Projects & 28 & 0 & 0 & 0 & 28 \\
\hline Liquid Waste Handling Facility & 24 & 0 & 0 & 0 & 24 \\
\hline PNL - 326 Bldg - D8D & 0 & 7 & 11 & 0 & 18 \\
\hline Fuels Operations & 17 & 0 & 0 & 0 & 17 \\
\hline CP Purex \& U03-224U Facilities & 14 & 0 & 0 & 0 & 14 \\
\hline DUM Sol Ust Ops - D\&D & 0 & 7 & 6 & $\mathbf{0}$ & 13 \\
\hline Stanford Lin Accel erator Cntr & 11 & 0 & 0 & 0 & 11 \\
\hline K-Basin Operations & 8 & 0 & 0 & 1 & 9 \\
\hline General Atomics & 9 & 0 & 0 & 0 & 9 \\
\hline Univ. of Utah & 6 & 0 & 0 & 0 & 6 \\
\hline Univ. of CA, Davis & 5 & 0 & 0 & 0 & 5 \\
\hline B Plant/MESF Facilities & 4 & 0 & 0 & $\mathbf{0}$ & 4 \\
\hline PHL - 324 Bldg - D\&D & 0 & 3 & 0 & 0 & 3 \\
\hline Geo. Tech. Engineering Lsb. & 0 & 0 & 3 & 0 & 3 \\
\hline DWM Sol id Waste Operations & 0 & 0 & 0 & 3 & 3 \\
\hline ARD Large Sodium fire Facility & 1 & 0 & 0 & $\mathbf{0}$ & 1 \\
\hline T-Plant Head End Cleanup & 0 & 0 & 0 & 0 & 0 \\
\hline ARD Fuel Fabrication Bldg. & 0 & 0 & 0 & 0 & 0 \\
\hline TOTAL & 88,112 & 14,710 & 11,601 & 8,766 & 123,189 \\
\hline
\end{tabular}

The majority of 55-gallon drums are generated by the Past Practice Remediation waste generator. This is the only container type Past Practice Remediation forecasts. $4^{\prime} \times 4^{\prime} \times 8^{\prime}$ boxes are generated primarily by Tank Farm Restoration, and Buried Equipment generates most of the unknown boxes.

\subsubsection{Remote-Handled Low-Level Mixed Waste}

The total amount of RH LLMW to be shipped to the SWOC over the next 30 years is approximately $97,8 \overline{5} 0 \mathrm{~m}^{3}$. Of the total RH LLMW forecasted, $90 \%$ will be shipped in LECs. Figure 3-5 displays the total RH LLMW volume by container type. Casks and 55-gallon drums each make up $4 \%$ of the waste, and $2 \%$ is in other miscellaneous containers. 
Figure 3-5. RH_LLMW Volumes by Container Type.

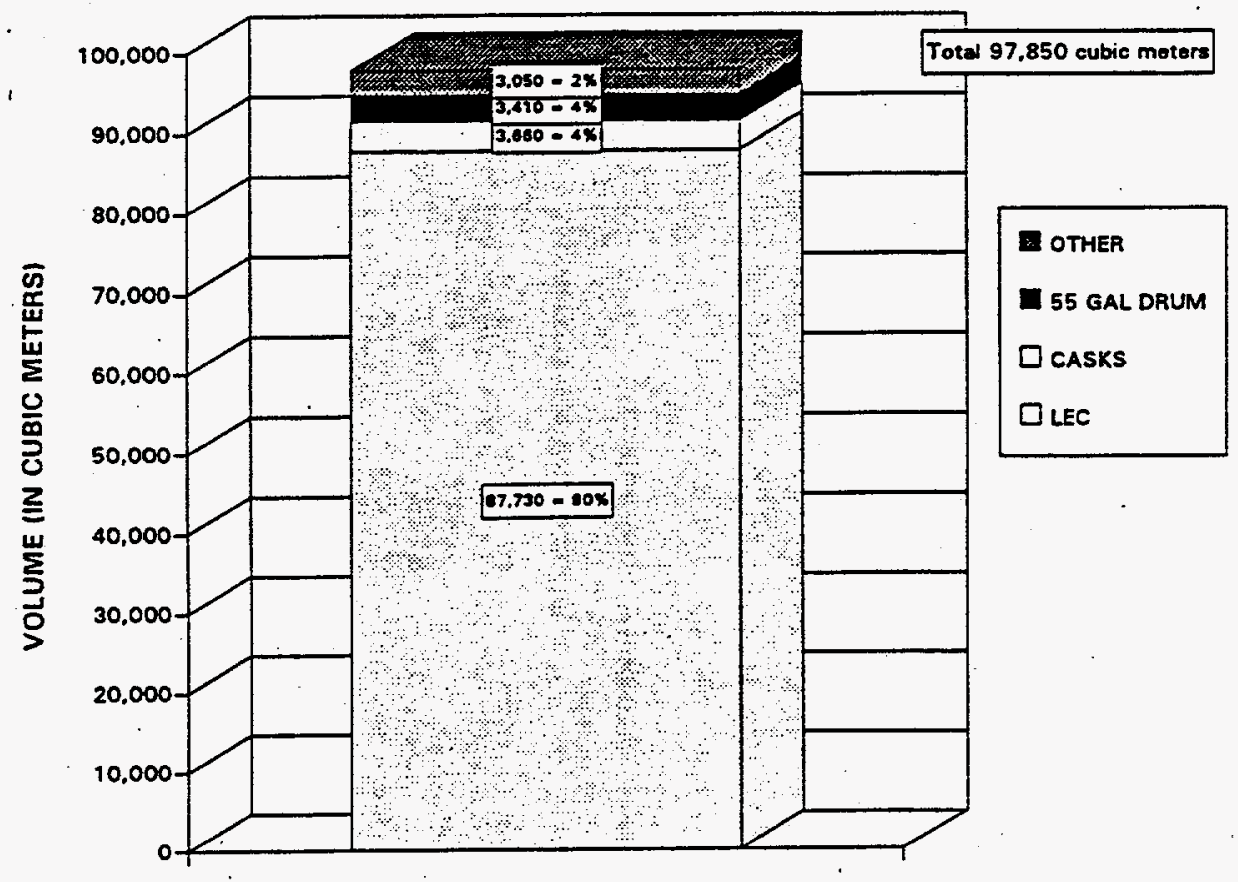

Figure 3-6 displays the annual volume of RH_LLMW by container type. The figure shows a gradual increase in waste volumes from 2003 through 2017 that represents the Long-Length Equipment shipping schedule. The major container type used during this time period is the LEC.

Figure 3-6. Annual Volume of RH_LLMW by Container Type.

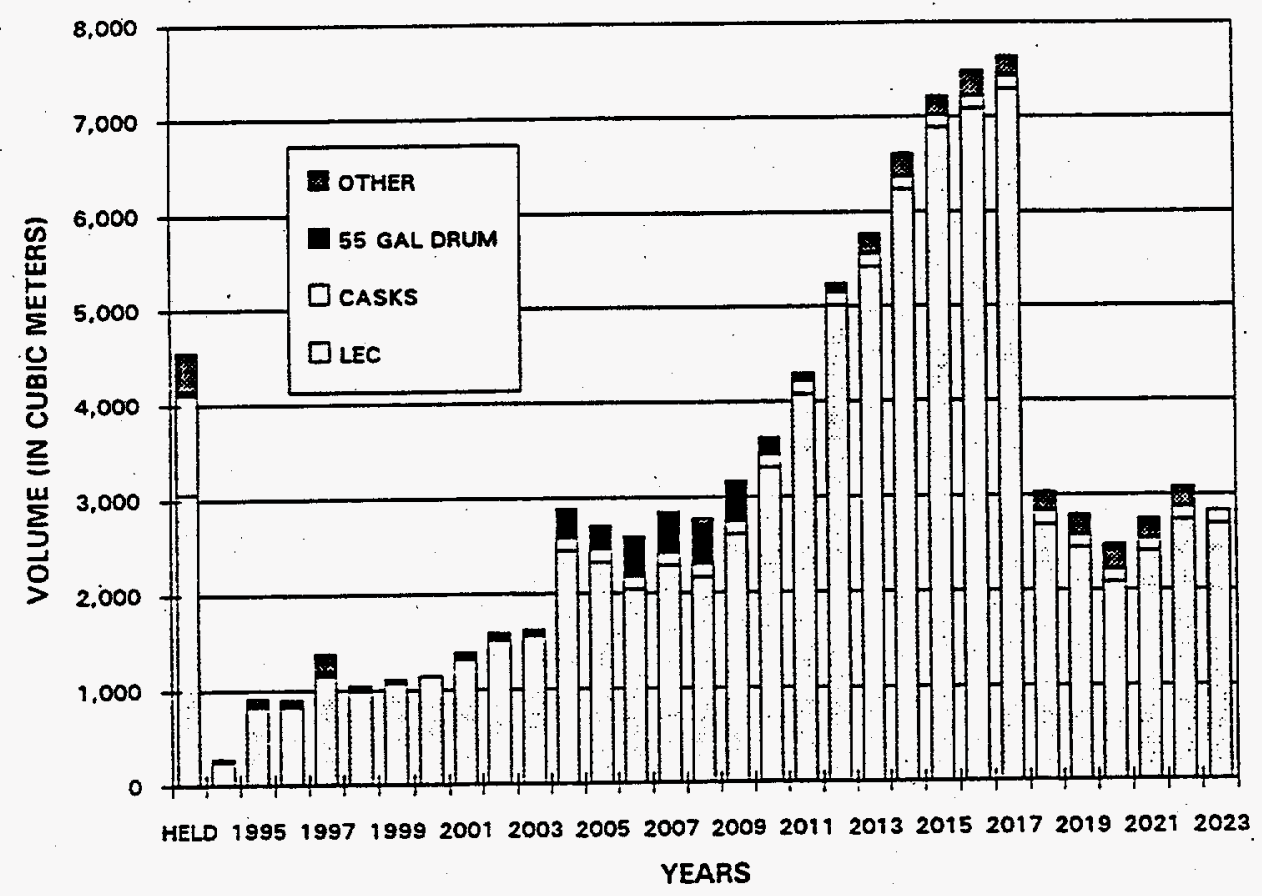


The waste generators for RH_LLMW by major container type are displayed in Table 3-2. The primary waste generator is Long-Length Equipment, which generates $90 \%$ of the waste. The remaining $10 \%$ wi 11 be generated by other miscellaneous generators. The primary waste generator that is planning on using LECS is the Long-Length Equipment waste generator. The low-level waste treatment facility is the only waste generator that has forecasted casks. Although the original project (LLW Grout Facility) has been cancelled, it is still included in this document because it is assumed that some sort of waste stabilization will still be required. Environmental Restoration Operations D\&D of Surplus Facilities is the primary producer of 55-gallon drums.

Table 3-2. RH LLMW Generators By Container Type.

\begin{tabular}{|c|c|c|c|c|c|}
\hline Waste Generator & LEC & CASKS & $\begin{array}{l}55 \text { GAL } \\
\text { DRUM }\end{array}$ & OTHER & Total \\
\hline Long-Length Equipment & 87,733 & 0 & 0 & $\underline{0}$ & 87,733 \\
\hline $\begin{array}{l}\text { LLW Treatment Facility (formerly DWM } \\
\text { Grout Facility) }\end{array}$ & 0 & 3,658 & 158 & 482 & 4,298 \\
\hline $\begin{array}{l}\text { Environmental Restoration Operations - } \\
\text { D\&D of Surplus Facilities }\end{array}$ & 0 & 0 & 2,770 & 0 & 2,770 \\
\hline T-Plant Bldg. - DED & 0 & $\mathbf{0}$ & 0 & 1,360 & 1,360 \\
\hline PHL - 324 Bldg - DED & 0 & 0 & 0 & 424 & 424 \\
\hline T-Plant Bldg. $2706 / 221$ & 0 & 0 & 312 & 0 & 312 \\
\hline W320 Tank 241 sluicing & 0 & 0 & 0 & 283 & 283 \\
\hline CP PUREX \& U03-224U Tunnel Waste & 0 & 0 & 0 & 242 & 242 \\
\hline CP 222-S Laboratory & 0 & 0 & 122 & 0 & 122 \\
\hline CP 222-S Laboratory- D\&D & $\mathbf{0}$ & 0 & 36 & 72 & 107 \\
\hline DLM B Plant \& MESF - D\&D & 0 & 0 & 0 & 69 & 69 \\
\hline CP Purex \& v03-2240 - D\&D & 0 & 0 & 0 & 59 & 59 \\
\hline A Evaporator - D\&D & 0 & 0 & 0 & 22 & 22 \\
\hline S Evaporator - Ded & 0 & 0 & 0 & 22 & 22 \\
\hline Pacific Northwest Laboratory & $\mathbf{0}$ & 0 & 14 & 0 & 14 \\
\hline I Evaporator - D\&D & 0 & 0 & 0 & 12 & 12 \\
\hline PHL - 326 Bldg - D8D & $\mathbf{0}$ & $\mathbf{0}$ & 0 & 7 & 7 \\
\hline TOTAL & 87,733 & 3,658 & 3,411 & 3,054 & 97,856 \\
\hline
\end{tabular}


WHC-EP-0803

This page intentionally left blank. 


\subsection{TRANSURANIC AND TRANSURANIC MIXED WASTE}

This section provides waste volumes by container type and waste category for TRU/TRUM waste. The major waste generators of TRU/TRUM waste are also described. TRU/TRUM waste will be treated and stored in the SWOC with u7timate disposal planned for the Waste Isolation Pilot Plant (WIPP) in Carlsbad, New Mexico.

\subsection{TRU/TRUM WASTE VOLUME}

The total amount of TRU/TRUM waste to be shipped to the SWOC over the next 30 years is approximately $86,100 \mathrm{~m}^{3}$. Of this waste, $56 \%$ is RH TRU/TRUM waste, while the remaining $44 \%$ is $\mathrm{CH}$ TRU/TRUM waste, as depicted in Figure 4-1. Figure 4-2 displays the major waste generators of TRU/TRUM waste. Twenty-eight percent is generated by D\&D of the Plutonium Finishing Plant; the tank farm low-level waste pretreatment facility generates $21 \%$; Long-Length Equipment generates $11 \%$; D\&D of the Hanford Waste Vitrification PIant (HWVP) and Past Practice Remediation generate $8 \%$ and $7 \%$, respectively; and the remaining $25 \%$ is generated by other miscellaneous waste generators. The major waste generators have been described in Section 2.0 with the exception of D\&D of the HWVP, whose description follows:

- D\&D of the Hanford Waste Vitrification Plant (HWVP): The HWVP is a future treatment/processing facility for tank waste that will require D\&D. Contaminated equipment includes cooling coils, pumps, and condensers.

Figure 4-1. Total Volume of TRU/TRUM Waste by Waste Category.

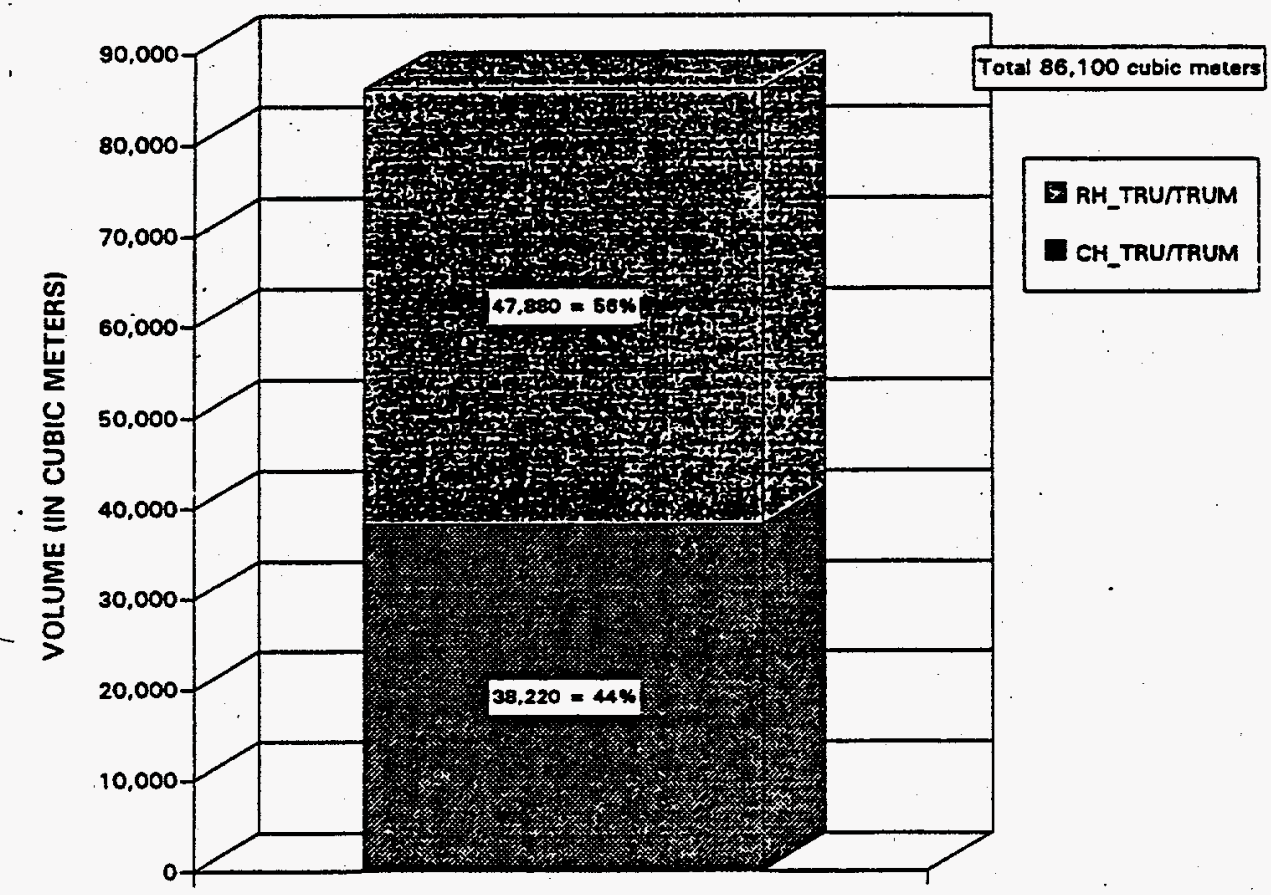


Figure 4-2. Major TRU/TRUM Waste Generators.

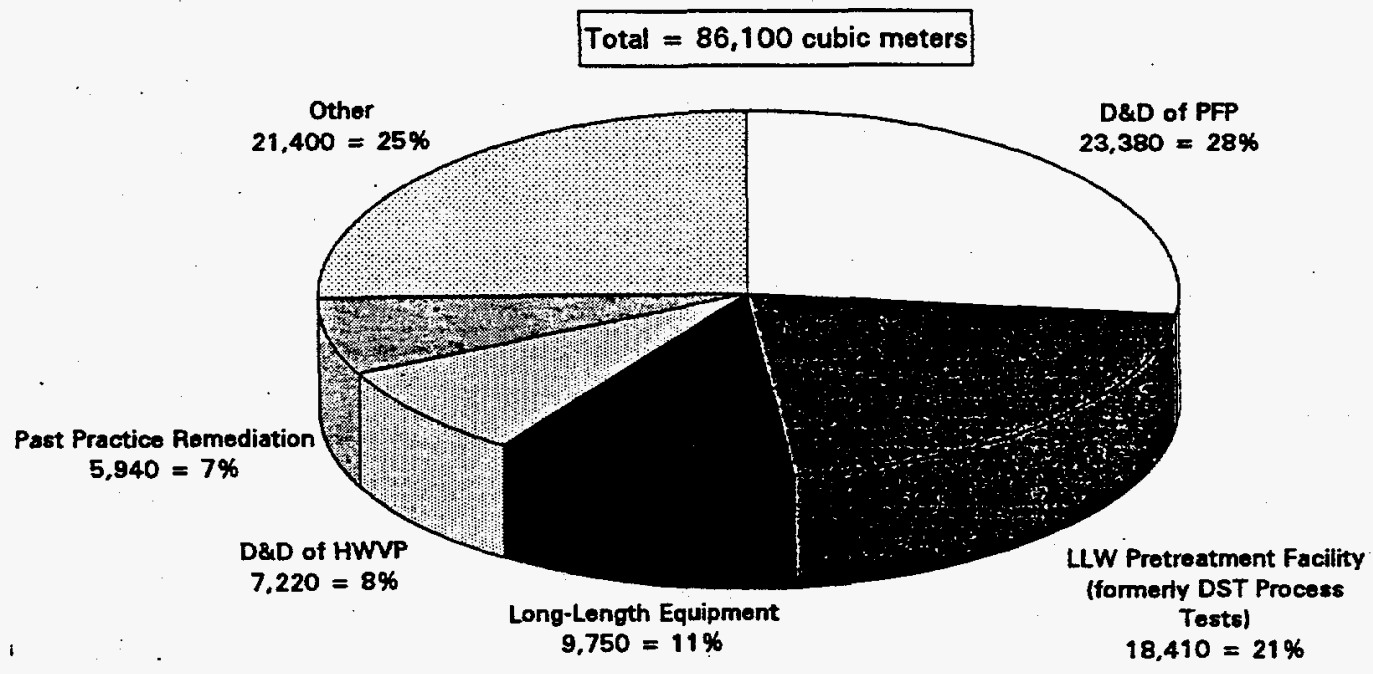

\subsection{TRU/TRUM WASTE CATEGORIES BY CONTAINER TYPE}

The following describes the volumes of each waste category of TRU/TRUM waste by container type. The total volume is discussed as are the annual volumes in terms of the main container types forecasted for shipment to the SWOC. The waste generators for each waste category are also described.

\subsubsection{Contact-Handled Transuranic/Transuranic Mixed Waste}

The total amount of CH TRU/TRUM waste to be shipped to the SWOC over the next 30 years is approximate- y $38,220 \mathrm{~m}^{3}$. Figure $4-3$ displays the total volume of $\mathrm{CH}$ TRU/TRUM waste by container type. As depicted in the figure, $50 \%$ will be shipped in unknown boxes; 40\% in 55-gallon drums; and the remaining $10 \%$ in other miscellaneous containers.

Figure 4-4 displays the annual volumes of $\mathrm{CH}$ TRU/TRUM waste by container type. As displayed in the figure, there is a fairily constant amount of waste until 2012, then the volume increases dramatically. The amount of waste is constant through 2022, which reflects the assumed shipping dates for the D\&D of the Plutonium Finishing Plant. The dates for shipment of D\&D waste from the Plutonium Finishing Plant are unknown, and an assumption was made that, until further planning has been completed, the waste would be shipped from 2013 through 2022. In addition, the figure displays a large amount of unknown boxes from 2013 through 2022 , which is reflective of the container type selected by the Plutonium Finishing Plant.

The waste generators of $\mathrm{CH}$ _TRU/TRUM waste by main container types are displayed in Table 4-1. D\&D of the Plutonium Finishing Plant generates $50 \%$ of the total waste. Past Practice Remediation generates $16 \%$, and maintenance of the Plutonium Finishing Plant generates $10 \%$. The majority of unknown boxes are generated by the D\&D of the Plutonium Finishing Plant. Fifty-five-gallon drums are generated primarily by Past Practice Remediation. 
WHC-EP-0803

Figure 4-3. CH_TRU/TRUM Waste Volumes by Container Type.

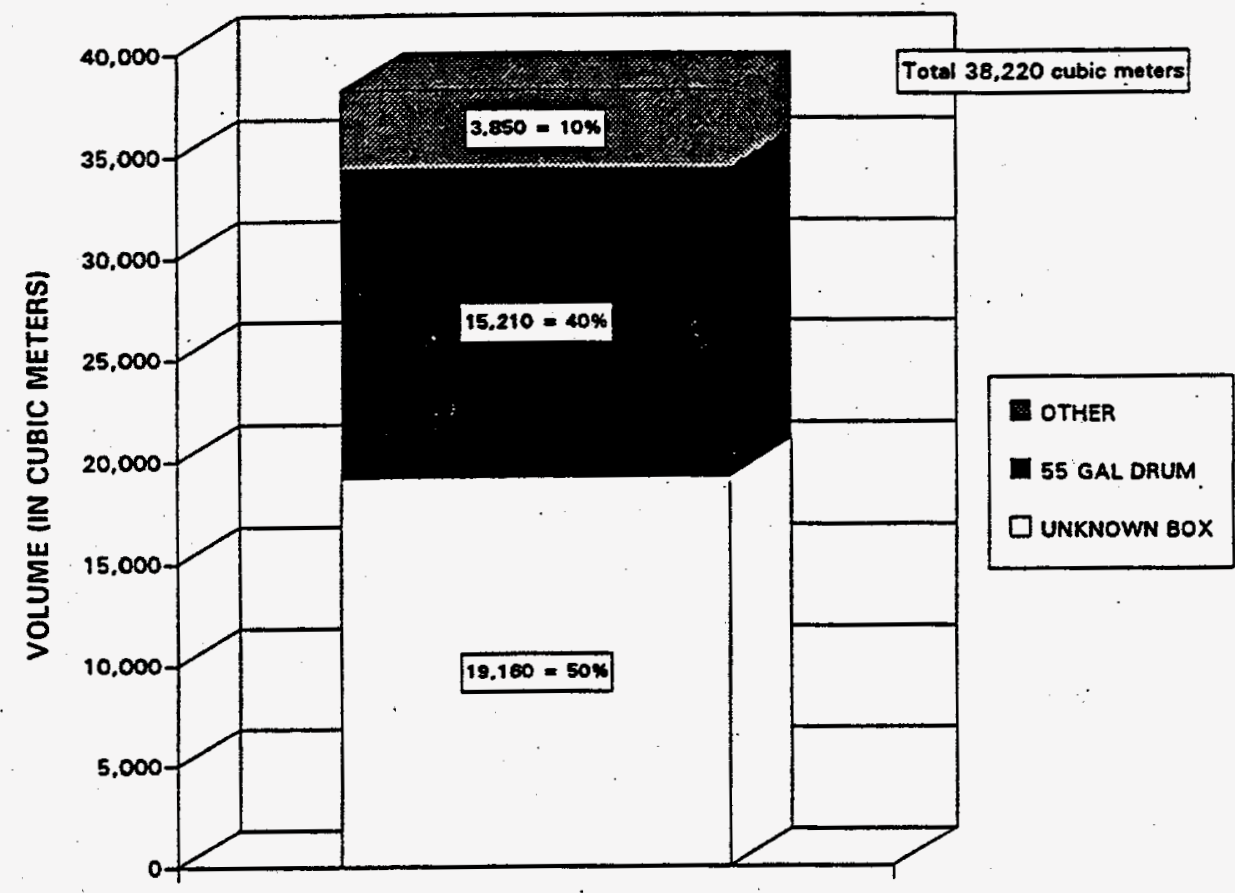

Figure 4-4. Annual Volume of CH_TRU/TRUM Waste by Container Type.

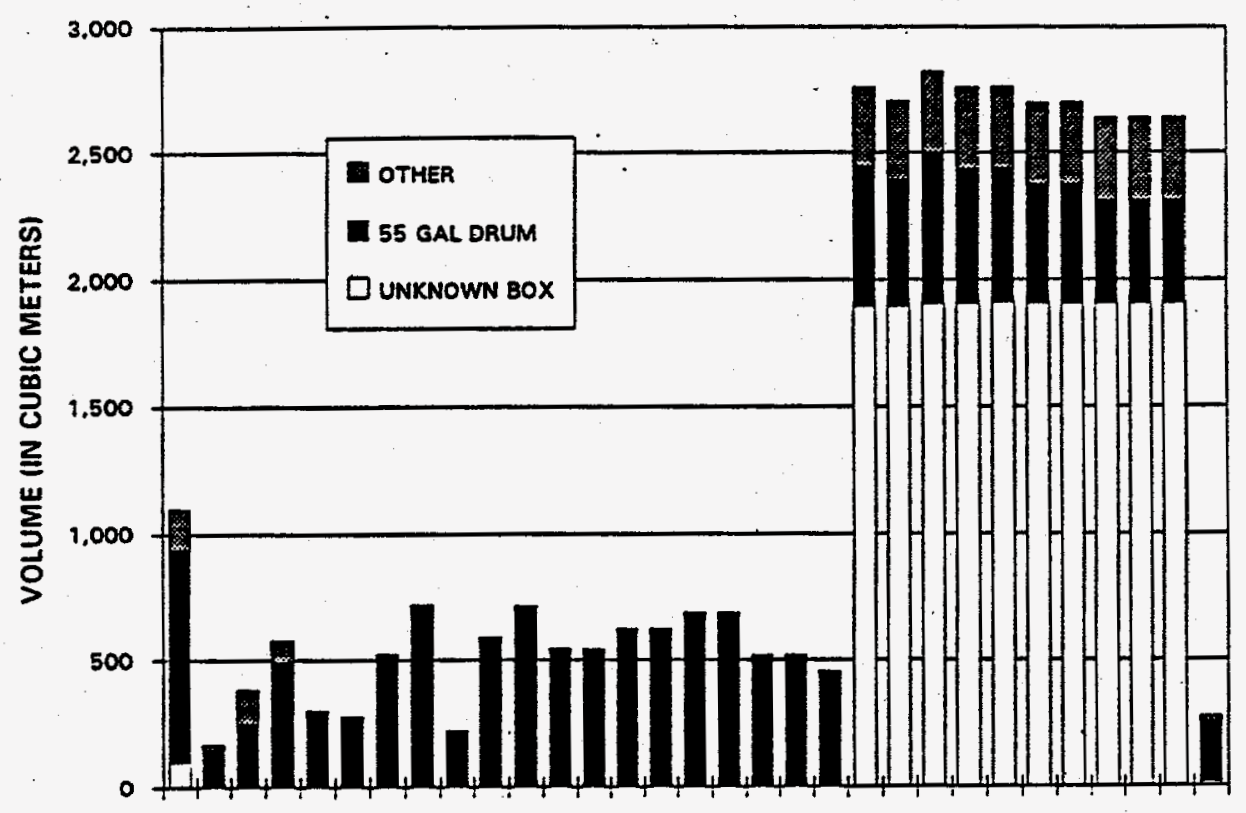

HELD 199519971999200120032005200720092011201320152017201920212023 YEARS 
Table 4-1. CH TRU/TRUM Waste Generators By Container Type.

\begin{tabular}{|c|c|c|c|c|}
\hline WASTE GENERATOR & $\begin{array}{c}\text { UNKNOWN } \\
\text { BOX }\end{array}$ & $\begin{array}{c}55 \mathrm{GAL} \\
\text { DRUM }\end{array}$ & OTHER & TOTAL \\
\hline Plutonium Finishing. Plant - D\&D & 17,199 & 126 & 1,379 & 18,704 \\
\hline Past Practice Remediation & 0 & 5,935 & 0 & 5,935 \\
\hline CP Plutonium Finishing Plant & 0 & 3,516 & 264 & 3,780 \\
\hline T-Plant Bldg. - D\&D & 1,360 & 850 & 1,360 & 3,570 \\
\hline PD Waste Vitrification Project & 210 & 1,633 & 158 & 2,002 \\
\hline $\begin{array}{l}\text { Environmental Restoration Operations } \\
- \text { D\&D of Surplus Facilities }\end{array}$ & 0 & 1,827 & 0 & 1,827 \\
\hline Lawrence Livermore Nat] Lab & 0 & 685 & 122 & 807 \\
\hline CP Purex \& U03-224U - D\&D & 385 & 0 & 219 & 604 \\
\hline Argonne Nat. Lab.-East & 0 & 185 & 0 & 185 \\
\hline SW Retrieval Fac.-Phase 2 & 0 & 183 & 0 & 183 \\
\hline K-Basin Operations & 0 & 0 & 133 & 133 \\
\hline CP Purex \& U03-224U Facilities & 0 & 40 & 77 & 117 \\
\hline Pacific Northwest Laboratory & 0 & 33 & 79 & 113 \\
\hline ARD Fuel Fab. Bldg. - D\&D & 0 & 86 & 5 & 90 \\
\hline SW Retrieval Fac.-Phase 1 & 0 & 46 & 0 & 46 \\
\hline SW RMW Storage Facility & 0 & 38 & 0 & 38 \\
\hline PNL - 231Z - D\&D & 2 & 0 & 32 & 34 \\
\hline PNL - 327 B1dg - D\&D & 0 & 0 & 27 & 27 \\
\hline Environmental Projects & 0 & 21 & 0 & 21 \\
\hline Lawrence Berkeley Lab & 0 & 3 & 0 & 3 \\
\hline Rockwell Canoga Park & 0 & 3 & 0 & 3 \\
\hline ARD Fuel Fabrication B1dg. & 0 & 1 & 0 & 1 \\
\hline Ames Laboratory-Ames, Iowa & 0 & 0 & 0 & 0 \\
\hline TOTAL & 19,157 & 15,208 & 3,855 & 38,220 \\
\hline
\end{tabular}

\subsubsection{Remote-Handled Transuranic/Transuranic Mixed Waste}

The total amount of RH_TRU/TRUM waste to be shipped to the SWOC over the next 30 years is approximatē $7 y=47,880 \mathrm{~m}^{3}$. Figure $4-5$ displays the total RH_TRU/TRUM waste volume by container type. of the total RH_TRU/TRUM waste forecasted, $39 \%$ will be shipped in casks. Unknown boxes comprise $28 \%$ of the waste, LECs make up 20\%, 55-gallon drums will contain 5\%, and the remaining $8 \%$ is in other miscellaneous containers. Figure 4-6 displays the annual volume 
WHC-EP-0803

Figure 4-5. RH_TRU/TRUM Waste Volumes by Container Type.

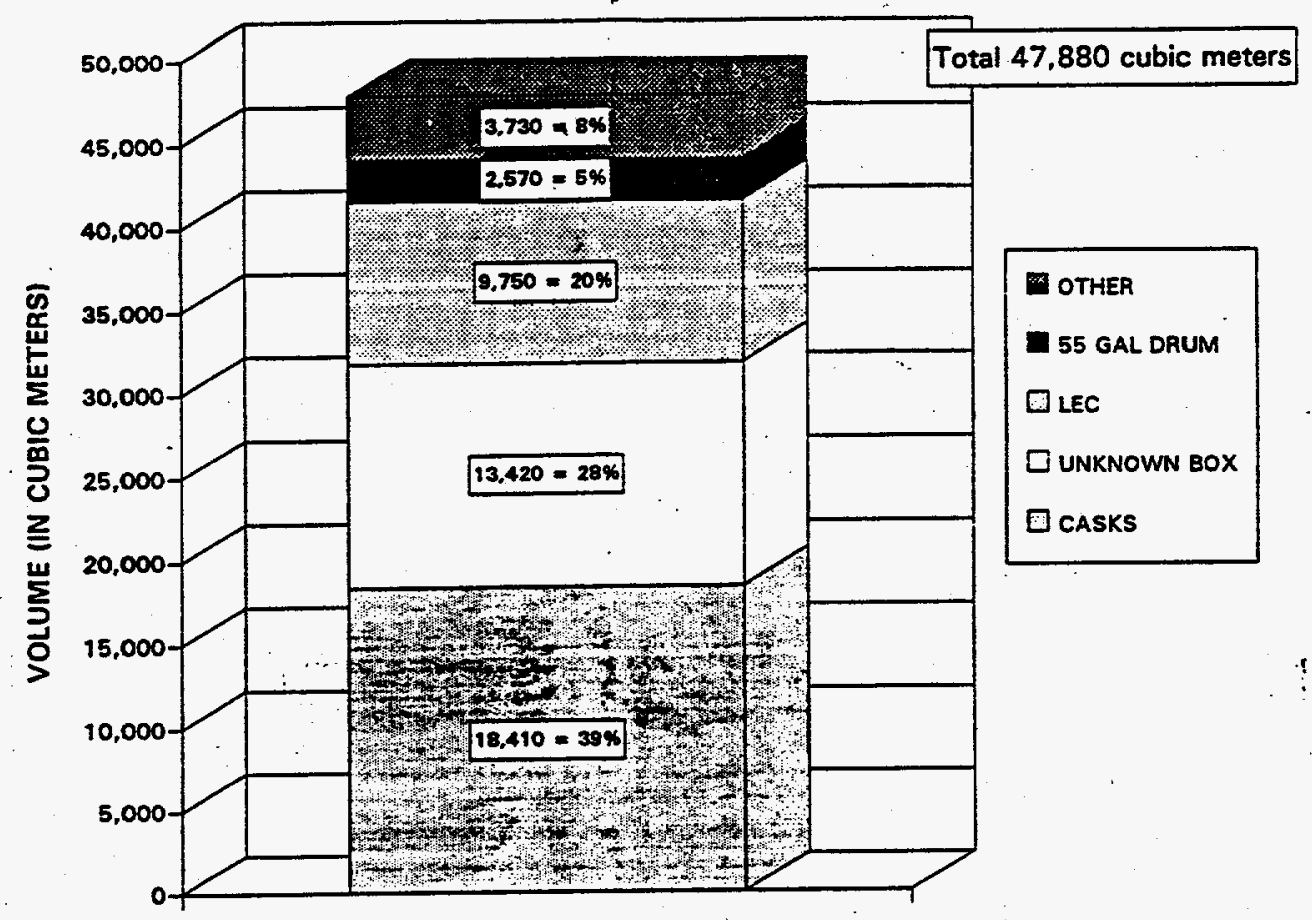

Figure 4-6. Annual Volume of RH_TRU/TRUM Waste by Container Type.

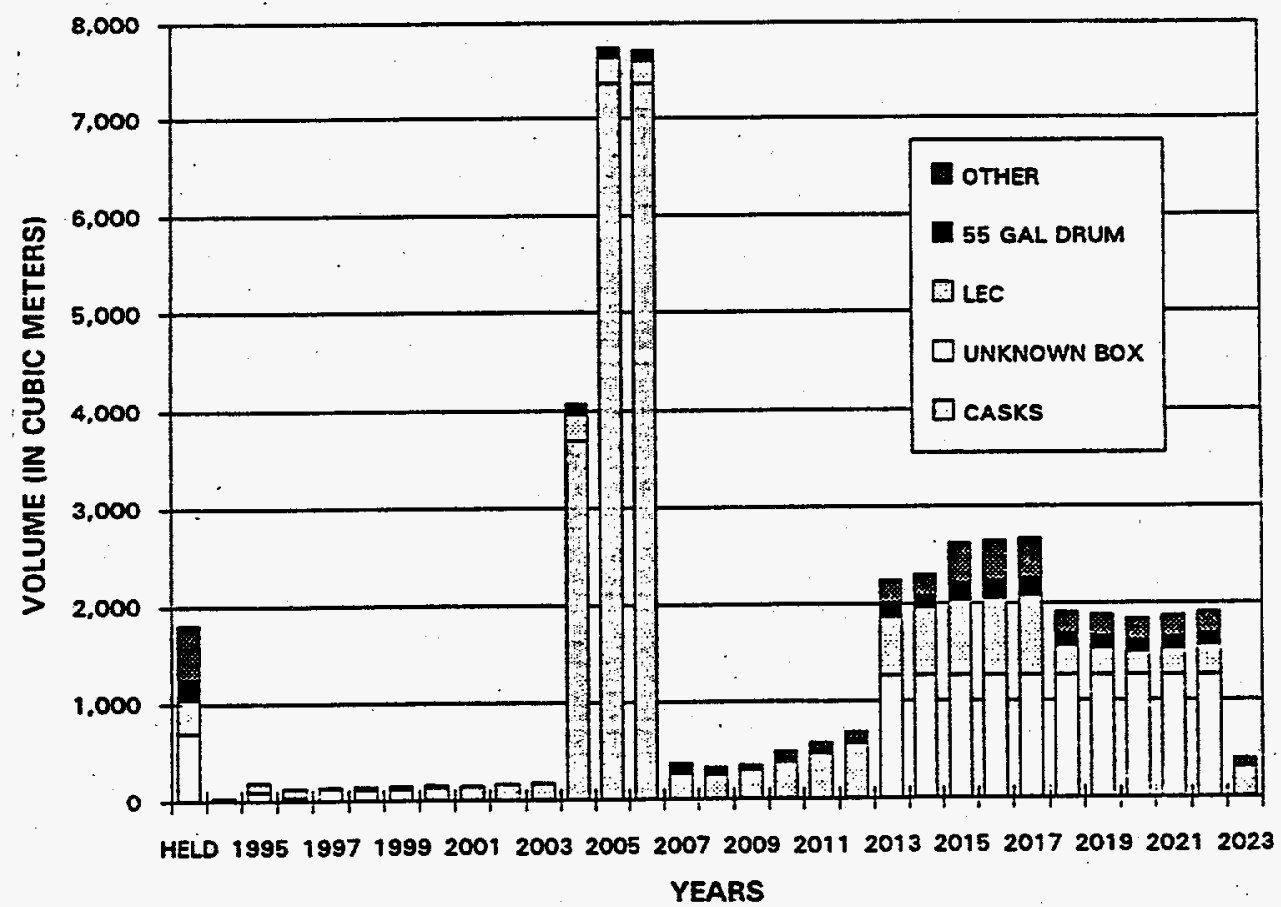


of RH_TRU/TRUM waste by container type. The figure depicts a dramatic increase in waste volumes from 2004 through 2006 that represents the shipment of casks from the low level waste retreatment facility (formerly OST Process Tasks).

The waste generators for RH TRU/TRUM waste by major container type are displayed in Table 4-2. The primary waste generator is the tank farm lowleve 1 waste pretreatment facility, which generates $38 \%$ of the waste. Twenty percent is generated by Long-Length Equipment and 15\% is generated by the D\&D of the HWVP. Casks are used solely by the low-level waste pretreatment facility. D\&D of the HWVP and the Plutonium Finishing Plant are the primary waste generators for unknown boxes. Long-Length Equipment is the main producer of LECS. Fifty-five-galion drums are evenly produced by D\&D of the HWVP, general operation of the HWVP, and Environmental Restoration Operation D\&D of Surplus Facilities.

Table 4-2. RH TRU/TRUM Waste Generators by Container Type.

\begin{tabular}{|c|c|c|c|c|c|c|}
\hline WASTE GENERATOR & CASKS & $\begin{array}{c}\text { UNKNOWN } \\
\text { BOX }\end{array}$ & LEC & $\begin{array}{c}55 \mathrm{GAL} \\
\text { DRUM }\end{array}$ & OTHER & TOTAL \\
\hline $\begin{array}{l}\text { Tank Farm LLW Pretreatment } \\
\text { Facility }\end{array}$ & 18,414 & 0 & 0 & 0 & $\mathbf{0}$ & 18,414 \\
\hline Long-Length Equipment & 0 & 0 & 9,748 & 0 & 0 & 9,748 \\
\hline PD Waste Vit Proj - D\&D & 0 & 6,428 & 0 & 716 & 71 & 7,215 \\
\hline $\begin{array}{l}\text { CP Plutonium Finishing } \\
\text { Plant - D\&D }\end{array}$ & 0 & 4,300 & 0 & 31 & 345 & 4,676 \\
\hline $\begin{array}{l}\text { PD Waste Vitrification } \\
\text { Project }\end{array}$ & 0 & 0 & 0 & 801 & 2,054 & 2,855 \\
\hline N-Reactor - D\&D & 0 & 1,186 & 0 & 0 & 0 & 1,186 \\
\hline PNL - 327 Bldg - D\&D & 0 & 171 & 0 & 2 & 849 & 1,023 \\
\hline T-Plant Bldg. - D\&D & 0 & 340 & 0 & 212 & 340 & 892 \\
\hline $\begin{array}{l}\text { Environmental Restoration } \\
\text { Operation - D\&D of Surplus } \\
\text { Facilities }\end{array}$ & 0 & 0 & 0 & 711 & 0 & 711 \\
\hline $\begin{array}{l}\text { CP PUREX \& U03-224U Tunnel } \\
\text { Waste }\end{array}$ & 0 & 697 & 0 & 0 & 0 & 697 \\
\hline CP Purex \& U03-224U - D\&D & 0 & 151 & 0 & 0 & 0 & 151 \\
\hline K-Basin Operations & 0 & 125 & 0 & 0 & 11 & 136 \\
\hline Battelle Columbus Labs. & 0 & 0 & 0 & 71 & 0 & 71 \\
\hline Argonne Nat. Lab.-East & 0 & 0 & 0 & 0 & 51 & 51 \\
\hline T-Plant Bldg. $2706 / 221$ & 0 & 0 & 0 & 28 & 0 & 28 \\
\hline Liq Wst Handling Fac - D\&D & 0 & 23 & 0 & 0 & 0 & 23 \\
\hline $\begin{array}{l}\text { Pacific Northwest } \\
\text { Laboratory }\end{array}$ & 0 & 0 & 0 & 0 & 1 & 1 \\
\hline TOTAL & 18,414 & 13,419 & 9,748 & 2,573 & 3,723 & 47,876 \\
\hline
\end{tabular}




\subsection{REFERENCES}

Armacost, L. L. 1994. Solid Waste 30-Year Volume Summary. WHC-EP-0768, Westinghouse Hanford Company, Richland, Washington.

Carver, M. 1993. Drums, DOT UN1A2, Solid Material, 114/208/322 Liter Salvage, Galvanized Steel. HS-V-P-0010, Westinghouse Hanford Company, Richland, Washington.

Cruse, J. 1992. Test and Evaluation Document for DOT Specification 7A Type A Packaging. WHC_EP-0558, Westinghouse Hanford Company, Richland, Washington.

McCormick, W. 1989. Safety Analysis Report for Packaging, Plywood Box. WHCSD-WM-SARP-003, Westinghouse Hanford Company, Richland, Washington.

McCormick, W. 1992. Safety Analysis Report for Packaging, Standard Waste Box. WHC-SD-TP-SARP-004, Westinghouse Hanford Company, Richland, Washington.

Titzler, P. 1993. Disposal of Tank Farm Long-Length Contaminated Equipment: Alternative Options Study and Engineering Support Information. WHC-SD-WM-265REV-0, Westinghouse Hanford Company, Richland, Washington.

Washington State Department of Ecology. 1993. Dangerous Waste Regulations. Washington State Administration Code, 173-303.

Westinghouse Hanford Company. 1990. Hazardous Materials Packaging Directory. WHC-SP-0364, Westinghouse Hanford Company, Richland, Washington.

Westinghouse Hanford Company. 1993. Radioactive Hazardous Materials Packaging Directory. WHC-SP-1070-REV-0, Westinghouse Hanford Company, Richland, Washington. 
WHC-EP-0803

This page intentionally left blank. 
WHC-EP-0803

\section{APPENDIX A}

\section{LOW-LEVEL WASTE VOLUMES AND CONTAINER TYPES}

A-1 
WHC-EP-0803

Page Left Intentionally Blank

A-2 
WHC-EP-0803

APPENDIX A

\section{LOW-LEVEL WASTE VOLUMES AND CONTAINER TYPES}

This appendix provides waste volumes by container type and waste category for low level waste (LLW). The major waste generators of LLW are also described. LLW will not be handled by the Solid Waste Operation Complex (SWOC) except for selective sampling. The majority of the LLW is currently planned to go directly to the Hanford LLW burial grounds. LLW is subdivided into two main waste categories, contact-handled and remote-handled LLW, which are described below.

- Contact-handled low-level waste (CH_LLW): This waste has a dose rate less than or equal to $200 \mathrm{mrem} / \mathrm{h}$ at contact with the waste container. The waste contains radioactivity that is not classified as transuranic waste, radioactive mixed waste, or spent nuclear fuel. The concentration of transuranic radionuclides is less than or equal to $100 \mathrm{nCi} / \mathrm{g}$ of the waste matrix.

- Remote-handled low-level waste (RH_LLW): This waste has a dose rate greater than $200 \mathrm{mrem} / \mathrm{h}$ at contact with the waste container. The waste contains radioactivity that is not classified as transuranic waste, radioactive mixed waste, or spent nuclear fuel. The concentration of transuranic radionuclides is less than or equal to $100 \mathrm{nCi} / \mathrm{g}$ of the waste matrix.

\section{A.1 LLW VOLUME}

The total amount of $L L W_{3}$ to be shipped to the SWOC over the next 30 years is approximately $1,496,560 \mathrm{~m}^{3}$. Of this waste, $96 \%$ is CH_LLW, while the remaining $4 \%$ is $\mathrm{RH}$ LLW, as depicted in Figure A.1. Figure A.2 displays the major waste generators of LLW. Seventy-four percent is generated by Environmental Restoration Operations - D\&D of Surplus Facilities; the Formerly Utilized Sites Remediation Action Program (FUSRAP) generates 4\%; decontamination and decommissioning (D\&D) of B P ant and the Paducah Energy Systems (ES) each generate $3 \%$; and the remaining $16 \%$ is generated by other miscellaneous waste generators. The following is a brief description of each generator:

- Environmental Restoration Operations - D\&D of Surplus Facilities: This includes all surplus listed facilities and projects. The current forecast does not address waste minimization, recycling, or reduction technologies that could reduce forecasted volumes by $30 \%$.

- FUSRAP: This is one of several U.S. Department of Energy (DOE) programs created to address radiological contamination in excess of guidelines at a number of sites throughout the United States. Generally, these sites, which became contaminated through uranium and thorium operation, were decontaminated and released for use 
Figure A.1. Total Volume of LLW by Waste Category.

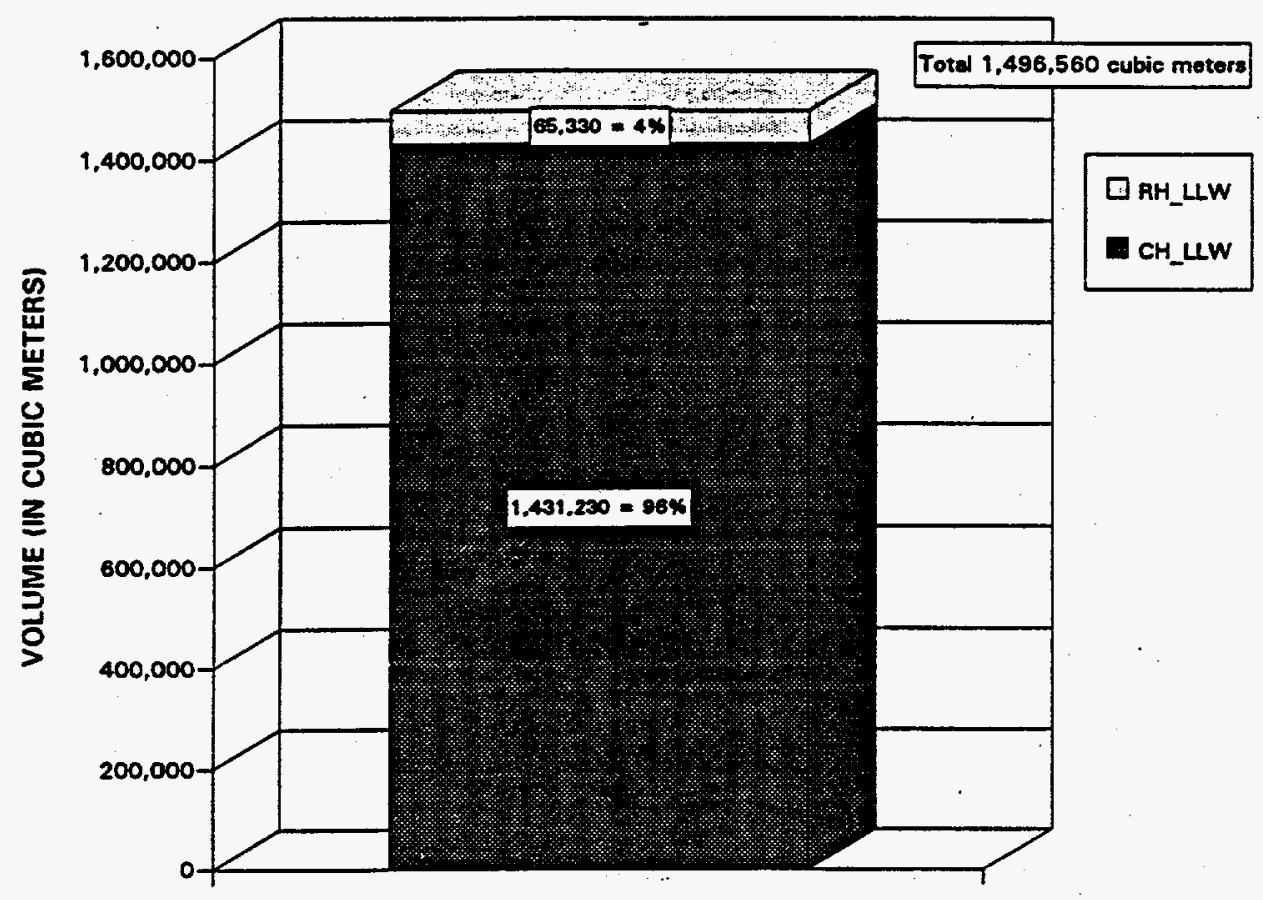

Figure A.2. Major LLW Generators.

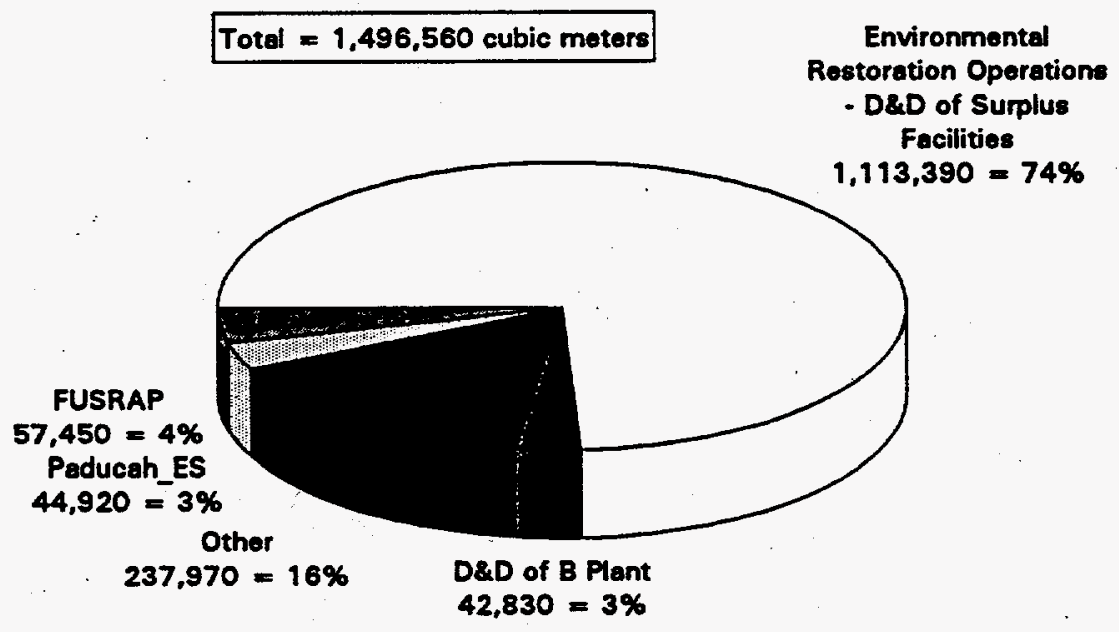


under the regulations in effect at the time. Because radiological guidelines were not as strict then as today, trace amounts of radioactive materials remained at some of the sites. Erosion, building demolition, and construction resulted in some of the radioactive residues mixing with large volumes of solid and rubble, thereby spreading the contamination. If FUSRAP becomes responsible for restoring more sites, its waste volumes could increase.

- D\&D of B-Plant: The volume estimates for B-Plant were determined by obtaining a building volume from the dimensions of the building. An assumption was made that $1 / 2$ of the building volume was contaminated material. In addition, $1 / 3$ of the Waste Encapsulation and Storage Facility (WESF) was assumed contaminated. Contaminated materials include tanks, jumpers, concentrators, ion exchange columns, filters, ducting, and condensers.

- Paducah Energy Systems: Forecasted waste volumes for this waste generator include ER and D\&D projects only. The waste to be shipped in FY 1994 through FY 1999 has already been generated; however, shipments have not been approved or funded at this time. Paducah has not yet determined a shipping schedule; thus the forecasted schedule is an estimation. It should be noted that U.S. Enrichment Corporation (USEC) has assumed responsibility for operational waste after July 1, 1993, and this waste is not included in the forecast.

\section{A.2 LLW CATEGORIES BY CONTAINER TYPE}

The following describes the LLW volumes by waste category and container type. The total volume is discussed as are the annual volumes in terms of the main container types forecasted for shipment to the SWOC. The waste generators for each waste category are also described.

\section{A.2.1 Contact-Handled Low-Level Waste}

The total amount of CH LLW to be shipped to the SWOC over the next 30 years is approximately $1,431,230 \mathrm{~m}^{3}$. Figure $A .3$ displays the total volume of CH_LLW by container type. As depicted in the figure, $51 \%$ will be shipped in $4^{\prime} \times 4^{\prime} \times 8^{\prime}$ boxes; $11 \%$ in 55 -gallon drums; $24 \%$ in unknown boxes; and the remaining $14 \%$ in other miscellaneous containers.

Figure A.4 displays the annual volumes of $\mathrm{CH}_{\text {LLWW }}$ by container type. As shown in the figure, there is a gradual increase in waste volume from 2002 through 2009. This peak represents the shipping schedule of $4^{\prime} \times 4^{\prime} \times 8^{\prime}$ boxes by the Environmental Restoration Operations -. D\&D of Surplus Facilities waste generator.

The waste generators for $\mathrm{CH}$ LLW by major container type are displayed in Table A.1. Environmental Restoration Operations - D\&D of Surplus Facilities generates $75 \%$ of the total waste, Oak Ridge National Laboratory generates $4 \%$, and Paducah Energy Systems generates $3 \%$. The majority of $4^{\prime} \times 4^{\prime} \times 8^{\prime}$ boxes 
Figure A.3. CH_LLW Volumes by Container Type.

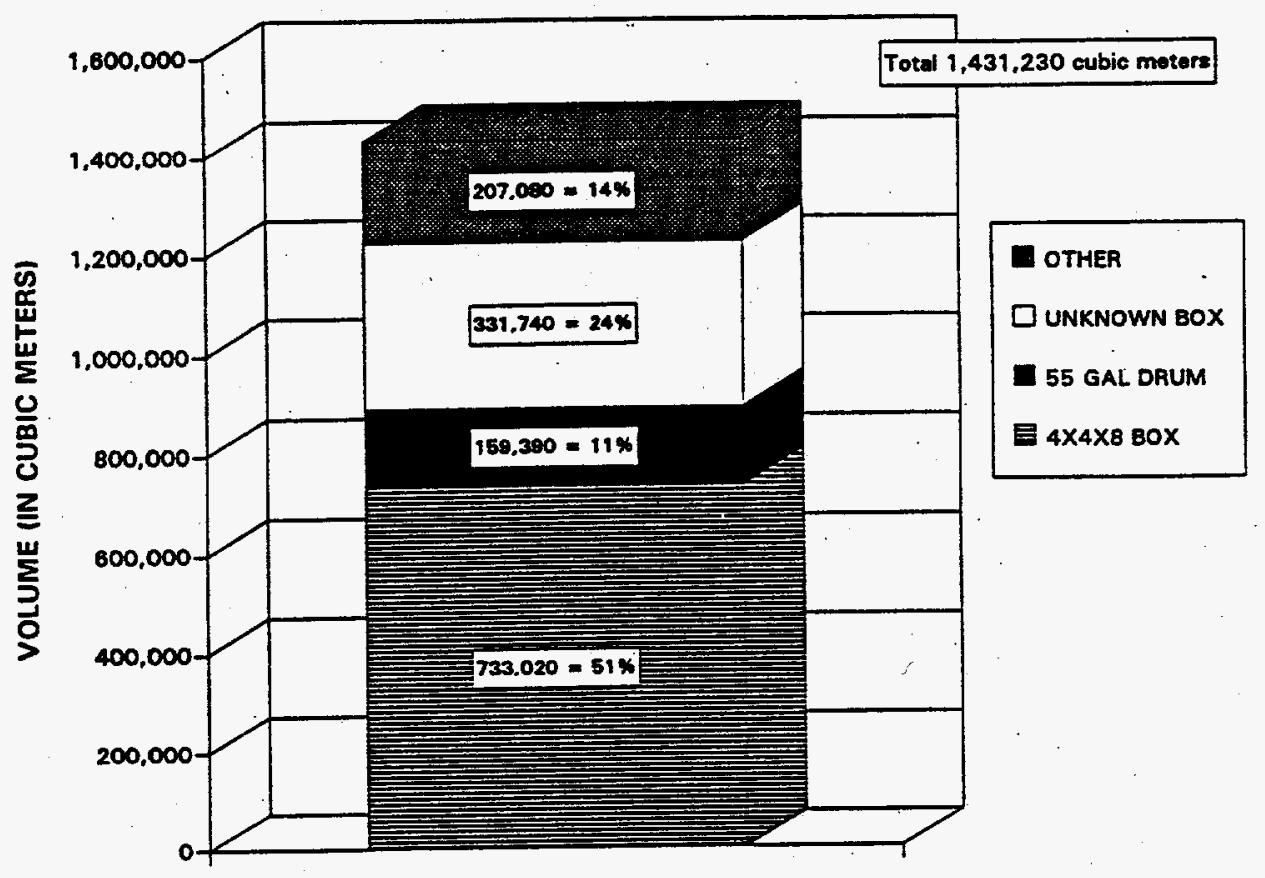

Figure A.4. Annual Volume of CH_LLW by Container Type.

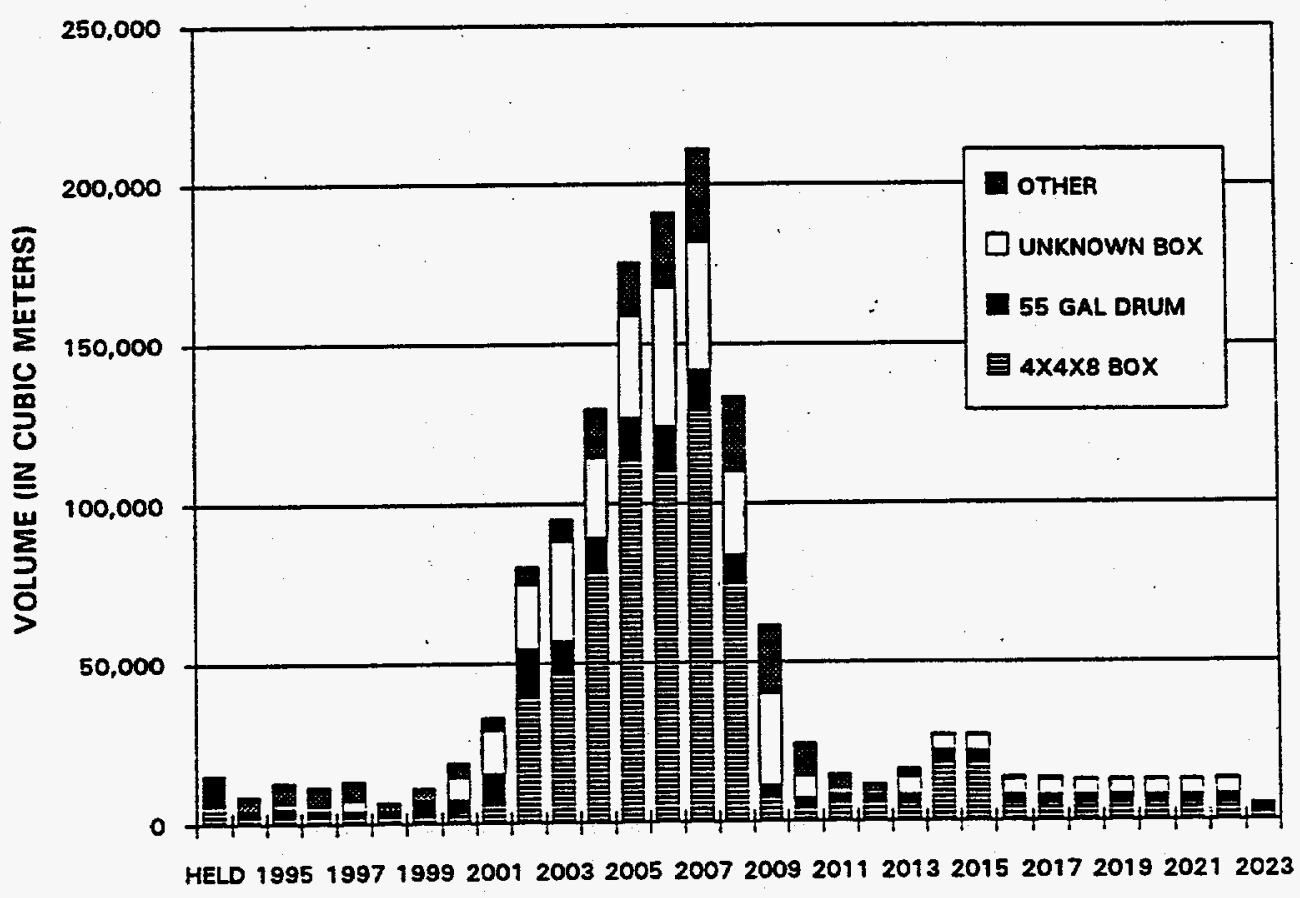

YEARS 
Table A.1. CH LLW Generators By Container Type.

\begin{tabular}{|c|c|c|c|c|c|}
\hline WASTE GENERATOR & $4^{1} \times 40 \times 81 \times 8$ & $\begin{array}{c}\text { BOX } \\
\text { OTHER }\end{array}$ & $\begin{array}{l}55 \text { GAL } \\
\text { DRUM } \\
\end{array}$ & OTHER & TOTAL \\
\hline $\begin{array}{l}\text { Environmental Restoration } \\
\text { Operations - D\&D of Surplus } \\
\text { Facilities }\end{array}$ & 582,653 & 285,532 & 50,630 & 154,633 & $1,073,448$ \\
\hline ORNL Oak Ridge Mational Lab. & 46,588 & 0 & 0 & 10,861 & 57,450 \\
\hline Paducah Energy Systems & 0 & 0 & 44,854 & 66 & 44,919 \\
\hline DLM B Plant \& WESF - D\&D & 2,270 & 31,997 & 0 & 0 & 34,267 \\
\hline PD Waste Vitrification Project & 14,554 & 0 & 15,198 & 0 & 29,753 \\
\hline CP 222-S Laboratory & 15,139 & 0 & 4,231 & 0 & 19,371 \\
\hline Single Shell Tank Farms & 14,641 & 0 & 299 & 301 & 15,240 \\
\hline Brookhaven & 11,164 & 0 & 2,952 & 0 & 14,115 \\
\hline CP 222-S Laboratory - D\&D & 0 & 3,661 & 9,078 & 64 & 12,803 \\
\hline Pacific Northwest Laboratory & 10,462 & 0 & 1,758 & 192 & 12,412 \\
\hline Lawrence Berkeley Lab & 0 & 0 & 641 & 10,039 & 10,680 \\
\hline Argonne Nat. Lab.-East & 0 & 0 & 5,122 & 3,909 & 9,032 \\
\hline$N$-Reactor - D\&D & 8,326 & 0 & 0 & 0 & 8,326 \\
\hline Portsmouth & 0 & 0 & 0 & 8,273 & 8,273 \\
\hline CP Plutonium Finishing Plant & 1,751 & 0 & 5,719 & 0 & 7,470 \\
\hline T-Plant Bldg. - D\&D & 3,572 & 3,572 & 0 & 0 & 7,144 \\
\hline Lawrence Livermore Natl Lab & 0 & 0 & 1,962 & 4,938 & 6,900 \\
\hline 300 Area Water Treatment Proj. & 0 & 0 & 6,261 & 0 & 6,261 \\
\hline Plasma Physics Laboratory & 0 & 0 & 1,011 & 4,996 & 6,006 \\
\hline Paducah Utility Services & 0 & 0 & 4,827 & 0 & 4,827 \\
\hline CP Purex \& yo3-224U - D\&D & 0 & 4,768 & 0 & 0 & 4,768 \\
\hline $\begin{array}{l}\text { LLW Treatment Facility } \\
\text { (formerly DWM Grout Facility) }\end{array}$ & 3,654 & $\mathbf{0}$ & 0 & 0 & 3,654 \\
\hline Laundry-Equip. Decon Facility & 3,480 & 0 & 0 & 0 & 3,480 \\
\hline Secondary Waste from LL Equip. & 3,293 & 0 & 0 & 0 & 3,293 \\
\hline PHL - 314 BLdg - DED & 1,589 & 1,589 & 0 & 0 & 3,178 \\
\hline K-Basin Operations & 122 & 0 & 1,078 & 1,273 & 2,473 \\
\hline PNL - 331 Bldg - DED & 1,746 & 162 & 0 & 0 & 1,908 \\
\hline Battell le Columbus Labs. & 0 & 0 & 0 & 1,772 & 1,772 \\
\hline Rockwell Canoga Park & 0 & 0 & 0 & 1,629 & 1,629 \\
\hline DRD 100 Area & 825 & 0 & 703 & $\underline{0}$ & 1,527 \\
\hline Stanford Lin Accelerator Cntr & 1,321 & 0 & 25 & 0 & 1,346 \\
\hline FERMI Nat. Accelerator Lab. & 0 & 0 & 175 & 1.016 & 1,191 \\
\hline PNL - 327 Bldg - D8D & 423 & 332 & 393 & 0 & 1,149 \\
\hline T-Plant Bldg. $2706 / 221$ & 1,076 & 0 & 71 & 0 & 1,147 \\
\hline PD Waste Vit Proj - D\&D & 1,105 & 0 & 0 & 0 & 1,105 \\
\hline Univ. of CA, Davis & 0 & 0 & 26. & 991 & 1,017 \\
\hline W343 DST Retrieval ( 17 Tanks) & 0 & 0 & 673 & 0 & 673 \\
\hline Knolls Atomic Power Shipyards & 0 & 0 & 0 & 633 & 633 \\
\hline
\end{tabular}


WHC-EP-0803

Table A.1. (contd).

\begin{tabular}{|c|c|c|c|c|c|}
\hline WASTE GENERATOR & $\begin{array}{c}4^{1} \times 4^{\prime} \times 8^{\prime} \\
80 \mathrm{x}\end{array}$ & $\begin{array}{c}\text { BOX } \\
\text { OTHER } \\
\end{array}$ & $\begin{array}{l}55 \text { GAL } \\
\text { DRUMY }\end{array}$ & OTHER & TOTAL \\
\hline SST Retrieval (149 tanks) & 591. & 0 & o & 0 & 591 \\
\hline General Atomics & 164 & 0 & 0 & 359 & 523 \\
\hline Ames Laboratory-Ames, lowa & 468 & 0 & 47 & D. & 515 \\
\hline DST Retrieval (10 Tanks) & 0 & 0 & 462 & 0 & 462 \\
\hline CP Purex \& y03-224U facilities & 194 & 0 & 249 & 0 & 443 \\
\hline Liquid Waste Handl ing Facility & 171 & 0 & 267 & 0 & 438 \\
\hline PHL - 324 Bldg - D\&D & 297 & 0 & 23 & 40 & 360 \\
\hline Bettis Atomic Power Laboratory & 0 & 0 & 0 & 355 & 355 \\
\hline EGRG Rocky Flats Plant & 0 & 0 & 131 & 156 & 286 \\
\hline DWM Grout Fac - D\&D & 276 & 0 & $\underline{0}$ & 0 & 276 \\
\hline Tank Farms Backlog Waste & 268 & 0 & 1 & 0 & 269 \\
\hline FFTF/FiNEF Maintenance. & 110 & 0 & 151 & 0 & 261 \\
\hline Fuels Operations & 229 & 0 & 0 & 0 & 229 \\
\hline B Plant/WESF facilities & 84 & 0 & 46 & 85 & 215 \\
\hline Liq Ust Handl ing Fac - D\&D & 0 & 0 & 0 & 198 & 198 \\
\hline Environmental Projects & 18 & 0 & 173 & 0 & 191 \\
\hline DWM Low Level Burial Grounds & 0 & 0 & 19 & 170 & 189 \\
\hline ARD Fuel Fab. Bldg. - D\&D & 116 & 0 & 12 & 0 & 129 \\
\hline Bettis Atomic Power Shipyards & 0 & 0 & 0 & 126 & 126 \\
\hline Cross-site Transfer Lines & 109 & 0 & 0 & 0 & 109 \\
\hline PHL - 242 Bldg - DED & 12 & 84. & 0 & $\mathbf{0}$ & 96 \\
\hline Tank Farm Ventilation Upgrade & 54 & 0 & 21 & $\underline{0}$ & 75 \\
\hline Kaiser Engineers & 0 & 0 & 61 & 0 & 61 \\
\hline Aging Waste Transfer Lines & 58 & 0 & 0 & 0 & 58 \\
\hline PML - 306H Bldg - DED & 13 & 31 & 7 & 0 & 51 \\
\hline Geo. Tech. Engineering Lab. & 7 & $\mathbf{0}$ & 19 & 0 & 26 \\
\hline PHL - 326 Bldg - DRD & 3 & 13 & 0 & 0 & 16 \\
\hline DHM Solid Waste Operations & 0 & 0 & 3 & 9 & 12 \\
\hline Univ. of Utah & 0 & 0 & 6 & 0 & 6 \\
\hline ARD 306E Bldg. FDL - D\&D & 5 & 0 & 0 & 0 & 5 \\
\hline ARD fuel Fabrication Bldg. & 4 & 0 & 1 & 0 & 5 \\
\hline Bates Accelerat. - Massachusetts & 0 & 0 & 4 & 0 & 4 \\
\hline Tank Farm-101-AZ Retrieval Sys & 0 & 0 & 4 & 0 & 4 \\
\hline Tank AP-104 Upgrade & 4 & 0 & 0 & 0 & 4 \\
\hline PHL - 2312 - D\&D & 4 & 0 & 0 & 0 & 4 \\
\hline CC, PFP\&NCRLDST Pilot Scale Ret & 0 & 0 & 1 & 0 & 1 \\
\hline Total. & 733,016 & 331,741 & 159,393 & 207,084 & $1,431,234$ \\
\hline
\end{tabular}


and unknown boxes are generated by Environmental Restoration Operations - D\&D of Surplus Facilities; 55-gallon drums are mainly generated by Environmental Restoration Operations - D\&D of Surplus Facilities and Paducah Energy Systems.

\section{A.2.2 Remote-Handled Low-Level Waste}

The total amount of RH LLW to be shipped to the SWOC over the next 30 years is approximately $6 \overline{5}, 330 \mathrm{~m}^{3}$. Of the total RH_LLW forecasted, $61 \%$ will be shipped in other cylinders. This container type is typically 74.5 inches in diameter and 72.5 inches high, which gives it an external volume of 179 cubic feet. This container type is basicaliy exclusive to the Environmental Restoration Operations - D\&D of Surplus Facilities waste generator and is used to ship their RH LLW. Figure A.5 displays the total RH LLW volume by container type. Unknown boxes comprise $17 \%$ of the waste; $15 \%$ is in $4^{\prime} \times 4^{\prime} \times 8^{\prime}$ boxes; and the remaining $7 \%$ is in other miscellaneous containers. Figure A.6 displays the annual volume of RH_LLW by container type. The figure shows a peak from 2002 through 2010 that rēpresents the shipping schedule of $4^{\prime} \times 4^{\prime} \times 8^{\prime}$ boxes from the Environmental Restoration Operations - D\&D of Surplus Facilities waste generator.

The waste generators for RH_LLW by major container type are displayed in Table A.2. The major waste generator is Environmental Restoration Operations - D\&D of Surplus Facilities, which contributes $61 \%$ of the total waste. D\&D of B-Plant generates 13\%, D\&D of the Hanford Waste Vitrification Plant (HWVP) generates $10 \%$, and the remaining $16 \%$ is generated by several generators. other cylinders are the main container type generated solely by Environmental Restoration Operations - D\&D of Surplus Facilities. Unknown boxes are primarily generated by D\&D of B-Plant, and $4^{\prime} \times 4^{\prime} \times 8^{\prime}$ boxes are generated mainly by D\&D of the HWVP.

Figure A.5. RH_LLW Volumes by Container Type.

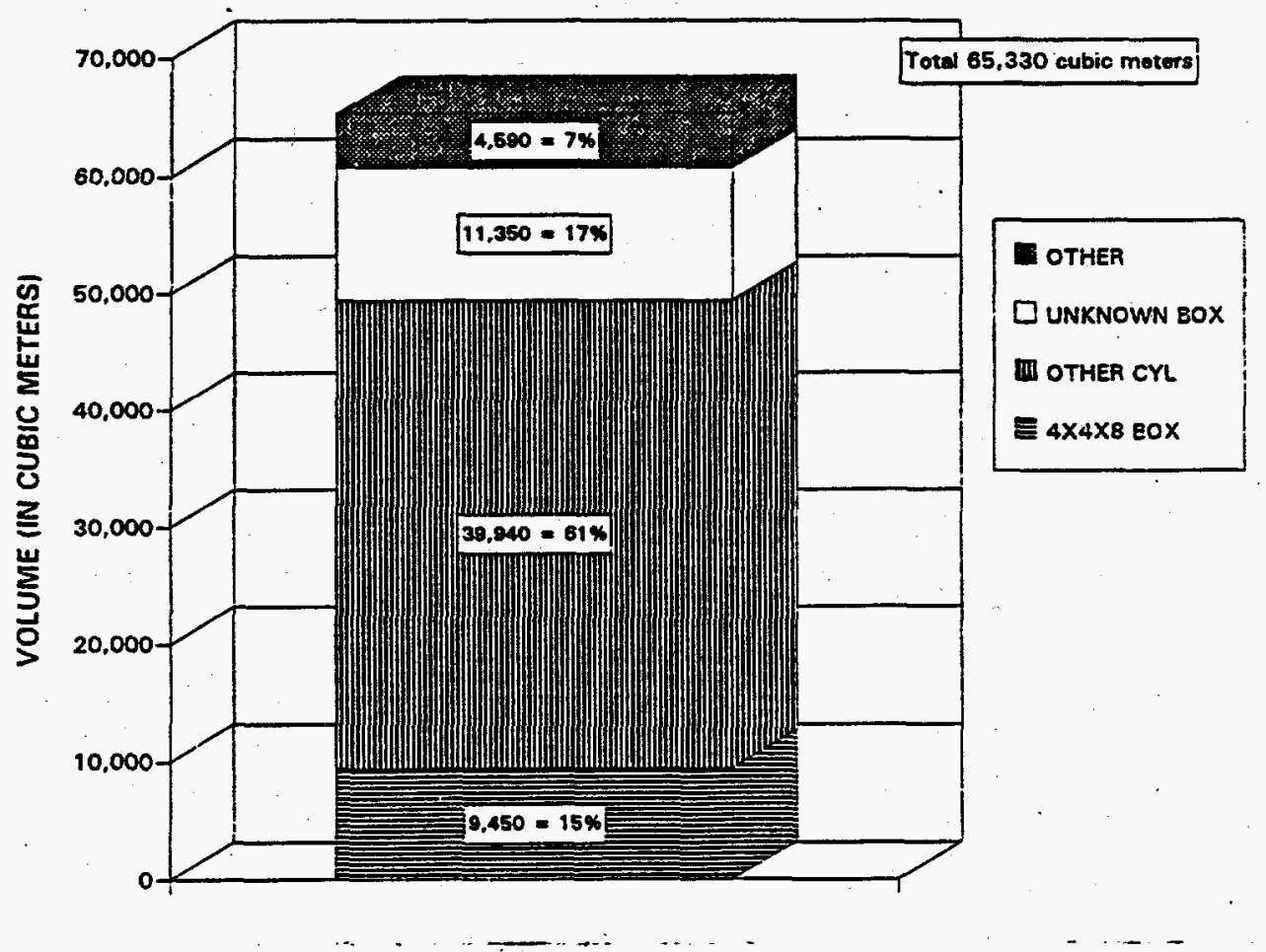


Figure A.6. Annual Volume of RH_LLW by Container Type.

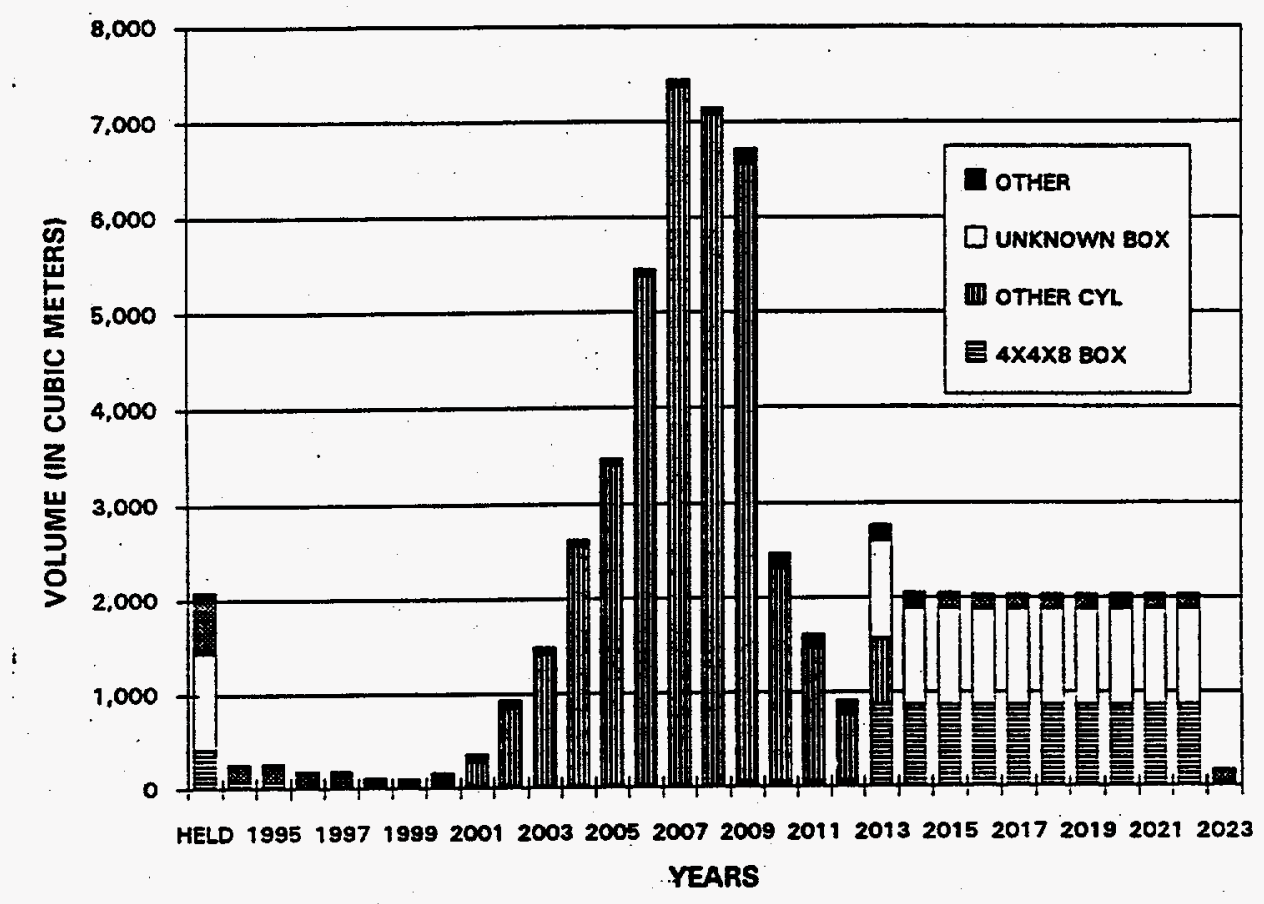


Table A.2. RH LLW Generators By Container Type.

\begin{tabular}{|c|c|c|c|c|c|}
\hline WASTE GENERATOR & $\begin{array}{l}\text { OTHER } \\
\text { CYCLE }\end{array}$ & $\begin{array}{c}\text { UNKNOWN } \\
\text { BOX }\end{array}$ & $4^{4} \times 4^{\prime} \times 8^{\prime}$ & OTHER & TOTAL \\
\hline $\begin{array}{l}\text { Enviromental Restoration Operations - } \\
\text { D\&D of Surplus Facilities }\end{array}$ & 39,943 & 0 & $\mathbf{0}$ & 0 & 39,943 \\
\hline DUM B Plant \& WESF - D\&D & O & 7,999 & 568 & 0 & 8,567 \\
\hline PO Waste Vit Proj - D\&D & 0 & 0 & 6,626 & 0 & 6,626 \\
\hline Po Uaste Vitrification Project & 0 & 0 & 1,191 & 1,807 & 2,999 \\
\hline T-Plant Bldg. - D\&D & 0 & 893 & 893 & 0 & 1,786 \\
\hline CP Purex \& U03-224U - D\&D & 0 & 1,192 & 0 & 0 & 1,192 \\
\hline FFTF/FMEF Maintenance. & 0 & $\underline{0}$ & 0 & 1,065 & 1,065 \\
\hline CP PUREX \& U03-224U Tunnel Ust - D\&D & 0 & 1,022 & 0 & 0 & 1,022 \\
\hline Pacific Northwest Laboratory & 0 & 0 & 0 & 919 & 919 \\
\hline K-Basin Operations & 0 & 236 & 0 & 193 & 429 \\
\hline PHL - 327 Bldg - DED & 0 & 6 & 0 & 308 & 315 \\
\hline T-Plant Bldg. $2706 / 221$ & 0 & 0 & 0 & 227 & 227 \\
\hline DRD 100 Aree & 0 & 0 & 136 & 0 & 136 \\
\hline Argonne Mat. Lab. -East & 0 & $\underline{0}$ & 0 & 33 & 33 \\
\hline PNL - 324 Bldg - D8D & 0 & 4 & 14 & 12 & 30 \\
\hline Environmental Projects & D & 0 & 0 & 13 & 13 \\
\hline Brookhaven & 0 & 0 & 11 & 0 & 11 \\
\hline $\begin{array}{l}\text { D\&D of LLW Treatment Facility } \\
\text { (formerly Grout Facility) }\end{array}$ & 0 . & $\mathbf{0}$ & 8 & 0 & 8 \\
\hline B Plant/UESF Facilities & 0 & 0 & 0 & 5 & 5 \\
\hline Total & 39,943 & 11,353 & 9,446 & 4,583 & 65,325 \\
\hline
\end{tabular}


WHC-EP-0803

This page intentionally left blank. 
WHC-EP-0803

APPENDIX B

\section{D\&D REFERENCES}

B-1 
WHC-EP-0803

Page Intentionally Blank 
WHC -EP-0803

APPENDIX B

\section{D\&D REFERENCES}

This appendix briefly describes the references used to obtain generator and volume information for decontamination and decommissiong (D\&D) waste generators and any assumptions made in using this information.

\section{B.1 IHE FISCAL YEAR (FY) 1993 SOLID WASTE FORECAST DATABASE:}

The forecast database contains only one generator of D\&D wastes, which is the Environmental Restoration Operations - D\&D of Surplus Facilities. These wastes have been estimated from projects and facilities currently under the D\&D program. These facilities are identified in the Surplus facilities Program Plan Fiscal Year 1993 and the Accelerated D\&D Schedule. The 1993 forecast for this generator only reported wastes for the years 1994-2013. It is expected that additional facilities will be identified and added to the Surplus Facility List after 2013.

\section{B.2 DRAFT REPORT: WASTE STREAM EVALUATION FOR LONG-TERM DECONTAMINATION STUDY:}

This special study investigated potential D\&D waste generators that are not on the Surplus Facilities List. Hundreds of facilities exist on the Hanford Site that will require D\&D. To limit the study, two sources were used to identify 26 facilities with potentially large D\&D volumes: the 1992 solid waste forecast database and the programmatic environmental impact statement database. Waste information was gathered primarily through interviews with operational and waste personnel. Some estimates were developed by briefly touring the building and estimating the amount of equipment or contaminated material. Data include rough estimates of the waste volumes by waste class, physical characteristics, and possible container types. The schedule for receiving this waste was assumed to occur from 2013 through 2022.

For the purpose of completing the 30-Year Summary Report, the following assumptions and data revisions were made:

- Only the volume and waste category data will be used.

- Building demolition and soil excavation activities will not be addressed; therefore, the physical waste category construction material and the waste generator Secondary Environmental Restoration were not used.

- Volumes for Purex and the Purex Tunnels were deleted for reasons stated in the next reference summary. 
- Volumes for the canyon buildings, B-Plant, T-Plant, and the Plutonium Finishing $\mathrm{Pl}$ ant were used, but a ratio of $80 \%$ contacthandled to $20 \%$ remote-handled was based upon personal conversation with Ken Hladek (WHC).

B.3 ESTIMATION OF PUREX EQUIPMENT AND MATERIALS THAT ARE CANDIDATES FOR REMOVAL AND WASTE PROCESSING DURING PUREX PLANT CLOSURE, WHC-IP-0977 (VALERO 1994)

The study is a detailed investigation of potential waste from Purex and the Purex Tunnels, two facilities not identified on the surplus facilities list that will eventually require D\&D.

For the purpose of completing the 30-Year Summary Report, assumptions were made and the following revisions were made:

- Because this study has no waste category separation of remotehandled versus contact-handled, a ratio of $80 \%$ contact-handled to $20 \%$ remote-handled was assumed based upon personal conversation with Ken Hiadek (WHC). 
WHC-EP-0803

APPENDIX C

ANNUAL CONTAINER TYPE VOLUMES BY WASTE CLASS

C-1 
WHC-EP-0803

Page Intentionally $\mathrm{Blank}$

C-2 
$6 / 15 / 94$

Waste Volumes by Container Type and Maste Class

(All Volumes in Cublc Meters)

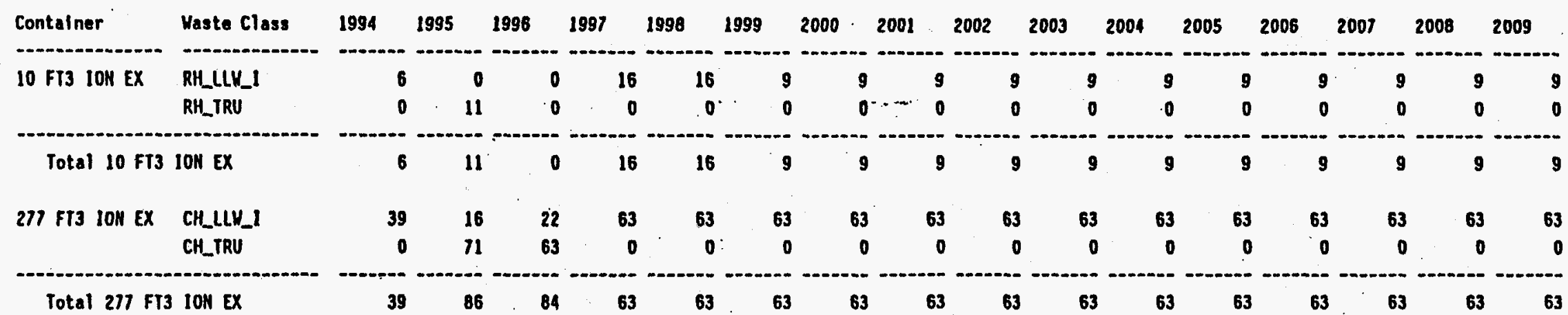

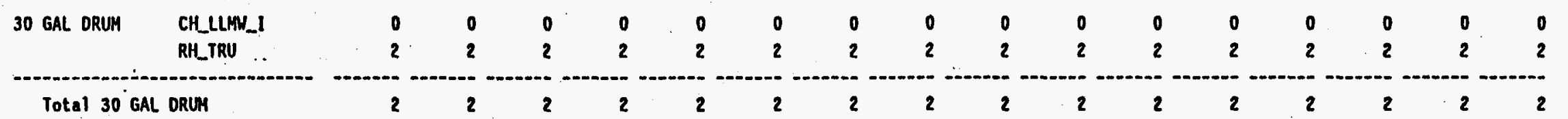

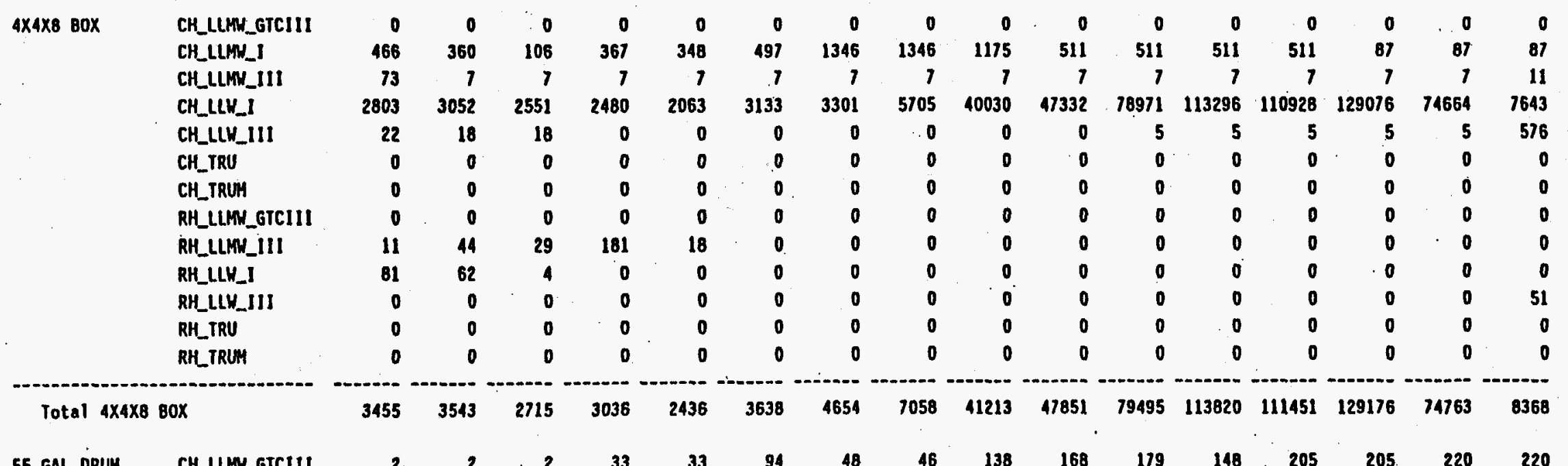

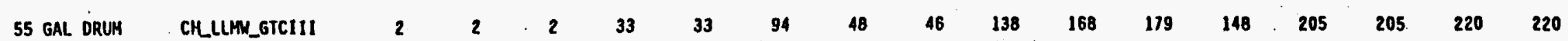


(All Volumes in Cublc Maters)

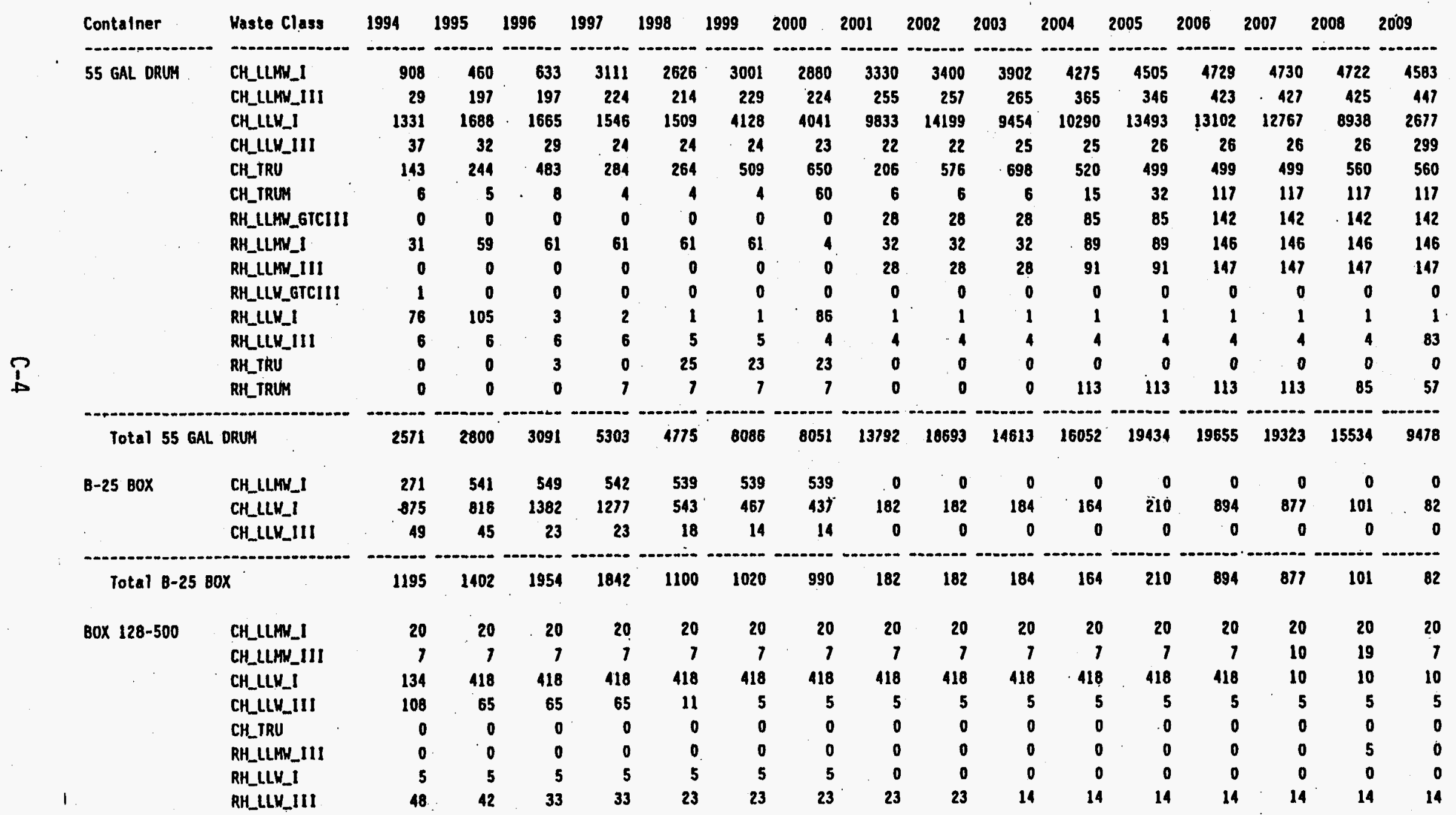





\begin{tabular}{|c|c|c|c|c|c|c|c|c|c|c|c|c|c|c|c|c|c|}
\hline :ontalner & Waste Class & 1994 & 1995 & 1996 & 1997 & 1998 & 1999 & 2000 & 2001 & 2002 & 2003 & 2004 & 2005 & 2006 & 2007 & 2008 & 2009 \\
\hline 30X OTHER & CH TRUM & 0 & , & 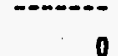 & . & 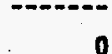 & & 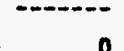 & 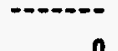 & 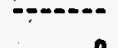 & -..... &..- & $\cdots$ & $\cdots$ & -..-- & $-\cdots--$ & $\ldots$ \\
\hline \multirow{9}{*}{ 30X OTHER } & DH_limen GTCII & 0 & 0 & & 0 & 0 & 0 & 0 & 0 & 0 & 0 & 0 & 0 & 0 & 0 & 0 & 0 \\
\hline & RH_LCMH_GICIII & 0 & 0 & 0 & 0 & 0 & 0 & 0 & 0 & 0 & 0 & 0 & 0 & 0 & 0 & 0 & 0 \\
\hline & RH_LLMN_I & 0 & 0 & 0 & 0 & 0 & 0 & 0 & 0 & 0 & 0 & 0 & 0 & 0 & 0 & 0 & 0 \\
\hline & RH_LLMM_III & $\mathbf{0}$ & 0 & 0 & 0 & 0 & 0 & 0 & 0 & 0 & 0 & 0 & $\mathbf{0}$ & 0 & 0 & 0 & 0 \\
\hline & RH_LLH_GTCIII & 0 & 0 & 0 & 0 & 0 & 0 & 0 & 0 & 0 & 0 & 0 & $\dot{0}$ & 0 & 0 & 0 & 0 \\
\hline & RH_LLH_I & 6 & 7 & 7 & 11 & 11 & 11 & 11 & 11 & 11 & 11 & 11 & 11 & 11 & 11 & 11 & 11 \\
\hline & RH_LLW_III & 0 & 0 & 0 & 0 & 0 & 0 & 0 & 0 & 0 & 0 & 0 & 0 & 0 & 0 & 0 & 0 \\
\hline & RH_TRU & 0 & 91 & 34 & 0 & 0 & 0 & 0 & 0 & 0 & 0 & o & 0 & 0 & 0 & 0 & 0 \\
\hline & RH_TRUH & o & 0 & 0 & 0 & 0 & 0 & 0 & 0 & 0 & 0 & 0 & 0 & 0 & 0 & 0 & 0 \\
\hline
\end{tabular}

$\begin{array}{ll}\text { ASKS } & \text { CH_LLU_III } \\ & \text { RH_LLM_III } \\ & \text { RH_LLH_III } \\ & \text { RH_TRUM }\end{array}$

Total CASKS

RH_TRUM

$\begin{array}{ll}\text {.EC } & \text { CH_LLMH_III } \\ & \text { CH_LLH_III } \\ & \text { RH_LLMH_III } \\ & \text { RH_TRUH }\end{array}$

\begin{tabular}{|c|c|c|c|c|c|c|c|c|c|c|c|c|c|c|c|}
\hline 39 & 39 & 42 & 42 & 8 & 0 & 0 & 0 & 0 & 0 & 0 & 0 & 0 & 0 & 0 & 0 \\
\hline 0 & 0 & 0 & 0 & 0 & 0 & 0 & 0 & 0 & 0 & 131 & 131 & 131 & 131 & 131 & 131 \\
\hline 16 & 16 & 111 & 95 & 32 & 32 & 32 & 32 & 32 & 32 & 32 & 32 & 32 & 32 & 32 & 32 \\
\hline 0 & 0 & 0 & 0 & 0 & 0 & 0 & 0 & 0 & 0 & 36893 & 7365 & 7365 & 0 & 0 & 0 \\
\hline
\end{tabular}

Total LEC

\begin{tabular}{|c|c|c|c|c|c|c|c|c|c|c|c|c|c|c|c|}
\hline 22 & 22 & 22 & 22 & 22 & 22 & 22 & 22 & 22 & 22 & 22 & 22 & 22 & 22 & 22 & 22 \\
\hline 32 & 0 & 0 & 32 & 96 & 32 & 32 & 32 & 0 & 0 & 0 & 0 & 0 & 0 & 0 & 0 \\
\hline 244 & 814 & 814 & 1140 & 977 & 1058 & 1140 & 1303 & 1506 & 1547 & 2443 & 2321 & 2036 & 2280 & 2158 & 2606 \\
\hline 27 & 90 & 90 & 127 & 109 & 118 & 121 & 145 & 167 & 172 & 271 & 258 & 226 & 253 & 240 & 290 \\
\hline 325 & 927 & 927 & 1320 & 1203 & 1230 & 1320 & 1501 & 1696 & 1741 & 2736 & 2600 & 2284 & 2555 & 2419 & 2917 \\
\hline
\end{tabular}

$\begin{array}{ll}\text { JTHER CYL } & \begin{array}{l}\text { CH_LLHH_I } \\ \text { CH_LLH_I } \\ \text { RH_LLH_GTCIII }\end{array}\end{array}$

\begin{tabular}{ll}
2 & 0 \\
0 & 0 \\
0 & 0 \\
\hline 2 & 0
\end{tabular}

Total OTHER CYL

ITHER DRUMS

CH_LLM_I

1450 
$6 / 15 / 94$

Waste Volumes by Contalner lype and Waste $\mathrm{Class}$

(AII Volumes in Cublc Meters)

\begin{tabular}{|c|c|c|c|c|c|c|c|c|c|c|c|c|c|c|c|c|c|}
\hline Container & Waste Class & 1994 & 1995 & 1996 & 1997 & 1998 & 1999 & 2000 & 2001 & 2002. & 2003 & 2004 & 2005 & 2006 & 2007 & 2008 & 2009 \\
\hline 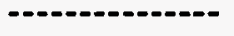 & - & $\rightarrow-\infty+\infty$ & & 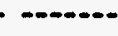 & $\cdots$ & $\cdots$ & - & 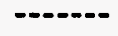 & -..-. & $m$ & -...... & $\cdots$ & - n..... & - & - & $\cdots$ & $-\infty$ \\
\hline \multirow[t]{7}{*}{ OTHER DRUMS } & CH_LLH_GTCIII & 0 & 0 & 0 & 0 & 0 & 0 & 0 & 283 & 850 & 1416 & 2550 & 3399 & 5382 & 7365 & 7082 & 6516 \\
\hline & CH_LLH_I & 0 & 0 & 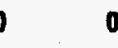 & 0 & 0 & 0 & 0 & 0 & 0 & o & 0 & 0 & 0 & 0 & o & 0 \\
\hline & CH_LLY_III & 0 & 0 & 6 & 6 & 0 & 11 & 1218 & 1133 & 2833 & 4249 & 8244 & 8782 & 12748 & 16997 & 12748 & 11048 \\
\hline & CH_TRU & 0 & 0 & 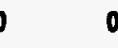 & 0 & 0 & 0 & 0 & 0 & 0 & 0 & 0 & 0 & 0 & 0 & 0 & 0 \\
\hline & RH_LLY_I & 0 & 0 & 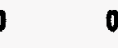 & 0 & 0 & 0 & 0 & 0 & 0 & 0 & 0 & 0 & 0 & 0 & 0 & 0 \\
\hline & RH_TRU & 0 & 0 & 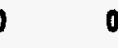 & 0 & 0 & 0 & 0 & 0 & 0 & 0 & 0 & 0 & 0 & $\mathbf{0}$ & 0 & 0 \\
\hline & RH_TRUH & 0 & 0 & 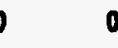 & 0 & 0 & 0 & 0 & 0 & 0 & 0 & 0 & 0 & 0 & 0 & 0 & 0 \\
\hline
\end{tabular}

Total OTHER DRUMS

1

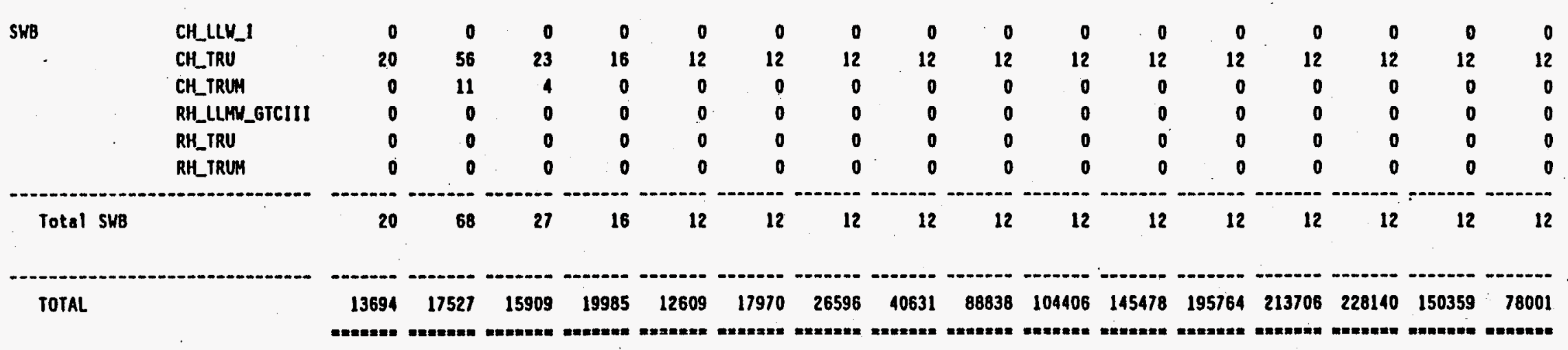




\begin{tabular}{|c|c|c|c|c|c|c|c|c|c|c|c|c|c|c|c|c|c|c|c|}
\hline Container & Waste Class & 2010 & 2011 & 2012 & 2013 & 2014 & 2015 & 2016 & 2017 & 2018 & 2019 & 2020 & 2021 & 2022 & 2023 & HELD & Total & Pct & \\
\hline "non & n & $--\infty-\infty-\infty$ & -- & --- & 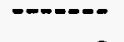 & - & (n...- & 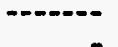 & & 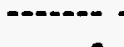 & $=-$ & 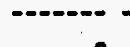 & & & & & & 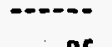 & \\
\hline \multirow[t]{2}{*}{10 FT3 ION EX } & RH_LLH_I & 9 & 9 & 9 & 9 & 9 & 9 & 0 & 0 & 0 & 0 & 0 & 0 & 0 & 0 & 0 & 193 & 95 & \\
\hline & RH_IRU & 0 & 0 & 0 & 0 & 0 & 0 & o & 0 & 0 & 0 & 0 & 0 & 0 & 0 & 0 & 11 & 5 & \\
\hline \multicolumn{2}{|c|}{ Total $10 \mathrm{FT3}$ ION } & 9 & 9 & 9 & 9 & 9 & 9 & 0 & 0 & 0 & 0 & 0 & 0 & 0 & 0 & 0 & 204 & 100 & \\
\hline \multirow[t]{2}{*}{277 FT3 ION EX } & CH_LLH_I & 63 & 63 & 63 & 63 & 63 & 63 & 0 & 0 & 0 & 0 & 0 & 0 & 0. & 0 & 0 & 1273 & 91 & \\
\hline & CH_TRU & 0 & 0 & 0 & 0 & 0 & 0 & 0 & o & 0 & 0 & 0 & 0 & 0 & 0 & 0 & 133 & 9 & \\
\hline \multirow{2}{*}{\multicolumn{2}{|c|}{ Total 277 FT3 ION EX. }} & & & & & & & 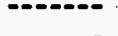 & 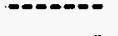 & -- & - & 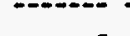 & - & - & 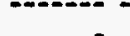 & 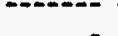 & 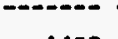 & 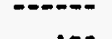 & \\
\hline & & 63 & 63 & 63 & 63 & 63 & 63. & 0 & 0 & 0 & 0 & 0 & 0 & 0 & 0 & 0 & 1406 & 100 & \\
\hline \multirow[t]{2}{*}{30 GAL DRUH } & CH_LLMH_I & 0 & 0 & 0 & 0 & 0 & 0 & 0 & 0 & 0 & 0 & 0 & 0 & 0 & 0 & 0 & 1 & 3 & \\
\hline & RH_TRU & 2 & 2 & 2 & 2 & 2 & 2 & 2 & 2 & 2 & 2 & 2 & 2 & 2 & 2 & 0 & 51 & 97 & $\Sigma$ \\
\hline \multicolumn{2}{|c|}{ Total 30 GAL DRUM } & 2 & 2 & 2 & 2 & 2 & 2 & 2 & 2 & 2 & 2 & 2 & 2 & 2 & 2 & 0 & 52 & 100 & m \\
\hline \multirow[t]{13}{*}{$4 \times 4 \times 880 X$} & CH_LLMY_GTCIII & 0 & 0 & $\mathbf{0}$ & - 91 & 91 & 91 & 91 & 91 & 91 & 91 & 91 & 91 & 91 & 0 & 0 & 910 & 0 & ᄋ \\
\hline & CH_LLMH_1 & 87 & 87 & 87 & 257 & 257 & 257 & 257 & 257 & 257 & 257 & 257 & 257 & 257 & 87 & 0 & 11234 & 1 & $\stackrel{\infty}{0}$ \\
\hline & CH_LLMM_III & 15 & 11 & 15 & 227 & 230 & 227 & 230 & 227 & 230 & 227 & 230 & 227 & 230 & 11 & 44 & 2566 & 0 & \\
\hline & CH_LLH_I & 4136 & 2526 & 2488 & 4507 & 4486 & 4388 & 4565 & 4452 & 4378 & 4468 & 4411 & 4381 & 4570 & 2555 & 1737 & 685017 & 90 & \\
\hline & CH_LLY_III & 576 & 3739 & 3739 & 650 & 14418 & 14418 & 650 & 650 & 650 & 650 & 650 & 650 & 650 & 576 & 4609 & 47939 & 6 & \\
\hline & CH_TRU & 0 & 0 & 0 & 129 & 129 & 129 & 129 & 129 & 129 & 129 & 129 & 129 & 129 & 0 & 0 & 1288 & 0 & \\
\hline & CH_TRUM & 0 & 0 & 0 & 148 & 148 & 148 & 148 & 148 & 148 & 148 & 148 & 148 & 148 & 0 & 0 & 1484 & 0 & \\
\hline & RH_LLM_GTCIII & 0 & 0 & 0 & 23 & 23 & 23 & 23 & 23 & 23 & 23 & 23 & 23 & 23 & o & 0 & 232 & 0 & \\
\hline & RH_LLMY_III & 0 & 0 & 0 & 45 & 45 & 45 & 45 & 45 & 45 & 45 & 45 & 45 & 45 & 0 & 0 & 736 & 0 & \\
\hline & RH_LLY_I & 0 & 0 & 0 & 147 & 147 & 147 & 147 & 147 & 147 & 147 & 147 & 147 & 147 & 0 & 0 & 1615 & 0 & \\
\hline & RH_LLK_III & 51 & 51 & 55 & 715 & 715 & 715 & 719 & 715 & 715 & 715 & 719 & 715 & 715 & 51 & 415 & 7831 & 1 & \\
\hline & RH_TRU & 0 & 0 & 0 & 32 & 32 & 32 & 32 & 32 & 32 & 32 & 32 & 32 & 32 & 0 & 0 & 325 & 0 & \\
\hline & RH_TRUM & 0 & 0 & 0 & 37 & 37 & 37 & 37 & 37 & 37 & 37 & 37 & 37 & 37 & 0 & 0 & 371 & 0 & \\
\hline \multirow{2}{*}{\multicolumn{2}{|c|}{ Total $4 \times 4 \times 8.80 X$}} & & & & & & & & & & & & & & & & & & \\
\hline & & 4865 & 6413 & 6383 & 7009 & 20760 & 20658 & 7075 & 6954 & 6884 & 6971 & 6921 & 6883 & 7076 & 3279 & 6806 & 761607 & 100 & \\
\hline 55 GAL DRUH & CH_LLMH_GTCIII & 135 & 107 & 78 & 66 & 63 & 63 & 48 & 48 & 33 & 33 & 18 & 18 & 18 & 2 & 48 & 2524 & 1 & \\
\hline
\end{tabular}




\begin{tabular}{|c|c|c|c|c|c|c|c|c|c|c|c|c|c|c|c|c|c|c|}
\hline Container & Waste Class & 2010 & 2011 & 2012 & 2013 & 2014 & 2015 & 2016 & 2017 & 2018 & 2019 & 2020 & 2021 & 2022 & 2023 & HELD & Total & Pct \\
\hline - & (1) & - - - & $\cdots$ & $\cdots$ & -.......... & $\cdots$ & $\cdots$ & 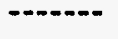 & - & - - - - - - & $\because+\infty-\infty$ & - & $\cdots$ & - & - & $-\ldots$ & -non & \\
\hline \multirow[t]{14}{*}{55 GAL DRUM } & CH_LLMU_1 & 3852 & 2569 & 1880 & 1877 & 1884 & 1888 & 1897 & 1897 & 1865 & 709 & 708 & 709 & 712 & 711 & 1036 & 75987 & 28 \\
\hline & CH_LLMY_III & 388 & 321 & 336 & 346 & 371 & 346 & 382 & 351 & 307 & 305 & 284 & 271 & 309 & 275 & 484 & 9601 & 4 \\
\hline & CH_LLK_L & 2091 & 1794 & 1822 & 2782 & 2835 & 2918 & 2718 & 2684 & 2700 & 2692 & 2691 & 2699 & 2707 & 1773 & 6719 & 152286 & 56 \\
\hline & CH_LLH_III & 299 & 299 & 299 & 304 & 304 & 304 & 304 & 304 & 304 & 304 & 304 & 304 & 304 & 303 & 2182 & 7108 & 3 \\
\hline & CH_TRU & 475 & 475 & 414 & 520 & 491 & 538 & 477 & 477 & 416 & 416 & 355 & 354 & 355 & 181 & 442 & 13584 & 5 \\
\hline & CH_TRUH & 32 & 32 & 32 & 32 & 3 & 53 & 53 & 53 & 53 & 53 & 53 & 53 & 53 & 53 & 398 & 1624 & 1 \\
\hline & RH_LLMN_GTCIII & 57 & 28 & 14 & 6 & 4 & 4 & 4 & 4 & 4 & 4 & 4 & 4 & 4 & 0 & 14 & 973 & 0 \\
\hline & RH_LLMH_I & 61 & 32 & 18 & 7 & 4 & 4 & 4 & 4 & 4 & 4 & 4 & 4 & 4 & 4 & 0 & 1357 & 1 \\
\hline & RH_LLMN_III & 62 & 34 & 20 & 8 & 6 & 6 & 6 & 6 & 6 & 6 & 6 & 6 & 6 & 6 & 45 & 1081 & 0 \\
\hline & RH_LLH_GTCIII & 0 & 0 & 0 & 0 & 0 & 0 & 0 & 0 & 0 & 0 & 0 & 0 & 0 & 0 & 24 & 33 & 0 . \\
\hline & RH_LLY_I & 1 & 1 & 1 & $B$ & 8 & 8 & 8 & 8 & 8 & $B$ & 8 & 8 & 8 & 1 & 0 & 368 & 0 \\
\hline & RH_LLY_III & 83 & 83 & 83 & 83 & 83 & 83 & 83 & 83 & 83 & 83 & 83 & 83 & 83 & 83 & 629 & 1943 & 1 \\
\hline & RH:TRU & 14 & 14 & 14 & 110 & 109 & 144 & 144 & 144 & 109 & 109 & 109 & 110 & 109 & 14 & 108 & 1433 & 1 \\
\hline & RH_TRUM & 42 & 42 & 42 & 42 & 14 & 48 & 48 & 48 & 14 & 14 & 14 & 14 & 14 & 14 & 108 & 1140 & 0 \\
\hline \multicolumn{2}{|c|}{ Total 55 GAL DRUH } & 7592 & 5831 & 5052 & 6190 & 6178 & 6404 & 6173 & 6109 & 5904 & 4739 & 4638 & 4636 & 4683 & 3425 & 12237 & 271042 & 100 \\
\hline \multirow[t]{3}{*}{ B-25 BOX } & CH_LLMH_1 & 0 & 0 & 0 & 0 & 0 & 0 & 0 & 0 & 0 & 0 & 0 & 0 & 0 & 0 & 0 & 3520 & 24 \\
\hline & CH_LLH_I & 80 & 80 & 80 & 82 & 62 & 108 & 792 & 650 & 101 & 82 & 80 & 80 & 80 & 82 & 0 & 11113 & 75 \\
\hline & CH_LLH_III & 0 & 0 & 0 & 0 & 0 & 0 & 0 & 0 & 0 & 0 & 0 & 0 & 0 & 0 & 0 & 186 & 1 \\
\hline \multicolumn{2}{|c|}{ Total B-25 BOX } & 80 & 80 & 80 & 82. & 62 & 108 & 792 & 650 & 101 & 82 & 80 & 80 & 80 & 82 & 0 & 14819 & 100 \\
\hline \multirow[t]{8}{*}{$80 \times \quad 128-500$} & CH_LLMH_I & 20 & 20 & 20 & 20 & 20 & 20 & 20 & 20 & 20 & 20 & 20 & 20 & 20 & 20 & 0 & 605 & 8 \\
\hline & CH_LLKH_III & 7 & 7 & 19 & 10 & 7 & 7 & 19 & 7 & 7 & 10 & 19 & 7 & 7 & 7 & 32 & 291 & 4 \\
\hline & CH_LLH_I & 10 & 10 & 10 & 30 & 30 & 30 & 30 & 30 & 30 & 30 & 30 & 30 & 30 & 10 & $\mathbf{0}$ & 5518 & 71 \\
\hline & CH_LLV_III & 5 & $\mathbf{5}$ & 5 & 5 & 5 & 5 & 5 & 5 & 5 & 5 & 5 & 5 & 5 & 5 & 0 & 447 & 6 \\
\hline & CH_TRU & 0 & 0 & 0 & 3 & 3 & 3 & 3 & 3 & 3 & 3 & 3 & 3 & 3 & 0 & 77 & 103 & 1 \\
\hline & RH_LLMH_III & 4 & 0 & 5 & 0 & 0 & 0 & 9 & 0 & 0 & 0 & 5 & 0 & 4 & 0 & 14 & 44 & \\
\hline & RH_LLV_I & 0 & 0 & 0 & 21 & 21. & 21 & 21 & 21 & 21 & 21 & 21 & 21 & 21 & 0 & 0 & 251 & \\
\hline & RH_LLK_III & 14 & 14 & 14 & 14 & 14 & 14 & 14 & 14 & 14 & 14 & 14 & 14 & 14 & 14 & 0 & 555 & \\
\hline
\end{tabular}




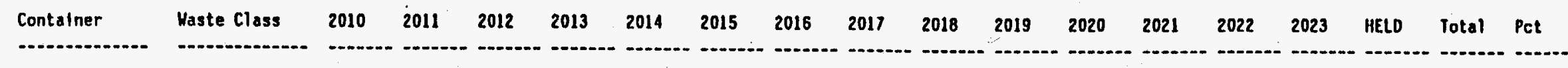

Total BoX 128-500

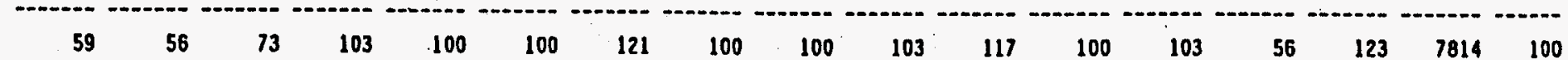

$80 \times 500-1000$

CH_LLM_I
CH_LLMH_III
CH_LLH_III
RH_LLMH_III
RH_TRU

Total BOX 500-1000

\begin{tabular}{|c|c|}
\hline \multirow{6}{*}{$80 x<128$} & \\
\hline & CH_LLRH_I \\
\hline & CH_LLMN_III \\
\hline & $\mathrm{CH}_{2} \mathrm{LLH} \mathrm{H}_{-} \mathrm{I}$ \\
\hline & CH_LLY_III \\
\hline & CH_tRU \\
\hline & RH_LLW_III \\
\hline
\end{tabular}

Total BOX $<128$

$\begin{array}{ll}\text { BOX }>1000 & \text { CH_LLH_I } \\ & \text { CH_LLL_III } \\ & \text { RH_LLMH_III }\end{array}$

Total BOX $>1000$

BOX OTHER

CH_LLH_GTCIII
CH_LLHW_I
CH_LLM_III
CH_LLH_GTCIII
CH_LLH_I
CH_LLH_III
CH_IRU

$\begin{array}{rrrr}0 & 0 & 0 & 0 \\ 26 & 0 & 0 & 0 \\ 0 & 0 & 0 & 0 \\ 0 & 0 & 51 & 0 \\ 0 & 0 & 0 & 73\end{array}$

$\begin{array}{rrr}0 & 0 & 0 \\ 26 & 0 & 0 \\ 0 & 0 & 0 \\ 0 & 0 & 51 \\ 73 & 73 & 73\end{array}$

$\begin{array}{rr}0 & 0 \\ 0 & 26 \\ 0 & 0 \\ 0 & 0 \\ 73 & 73\end{array}$

0
0
0
0
73

0
0
0
51
13

$\begin{array}{rr}0 & 0 \\ 0 & 26 \\ 0 & 0 \\ 0 & 0 \\ 73 & 73\end{array}$

0
0
0
0
0

\begin{tabular}{rrr}
0 & 15 & 1 \\
51 & 179 & 13 \\
0 & 161 & 12 \\
102 & 306 & 22 \\
0 & 726 & 52 \\
\hline 153 & 1388 & 100
\end{tabular}

\begin{tabular}{|c|c|c|c|c|c|c|c|c|c|c|c|c|c|c|c|c|}
\hline 6 & 6 & 9 & 6 & 6 & 9 & 6 & 6 & 9 & 6 & 6 & 9 & 6 & 6 & 0 & 2722 & 12 \\
\hline 0 & 0 & 0 & 0 & 2 & 0 & 0 & 0 & 0 & 3 & 0 & 0 & 0 & 0 & 5 & 322 & 1 \\
\hline 180 & 180 & 180 & 180 & 180 & 180 & 180 & 180 & 160 & 180 & 180 & 180 & 180 & 180 & 158 & 18530 & 80 \\
\hline 9 & 9 & 9 & 9 & 54 & . 9 & 18 & 35 & 18 & 9 & 9 & 9 & 9 & 9 & 0 & 1505 & 6 \\
\hline 0 & 0 & 0 & 0 & 0 & 0 & 0 & 0 & 0 & 0 & 0 & 0 & 0 & 0 & 2 & 2 & 0 \\
\hline 0 & 0 & 0 & 0 & 0 & 0 & 0 & 0 & 0 & 0 & 0 & 0 & 0 & 0 & 0 & 130 & 1 \\
\hline
\end{tabular}

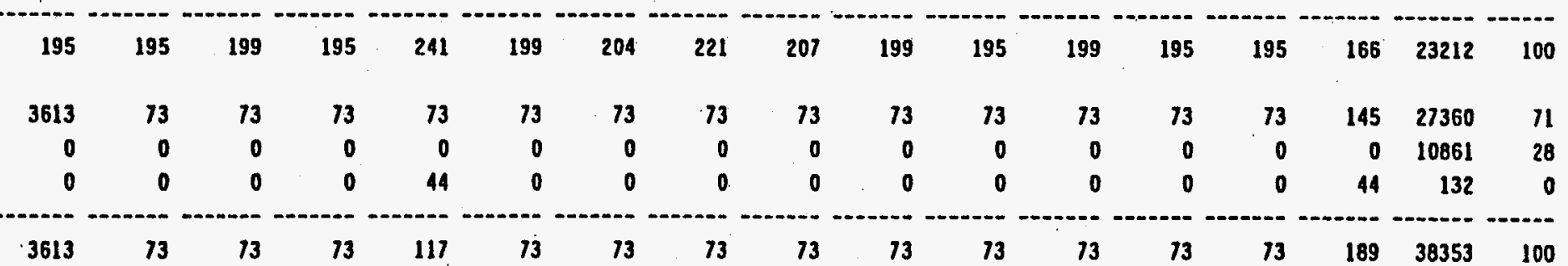

$\begin{array}{rrrr}0 & 0 & 0 & 94 \\ 170 & 170 & 227 & 292 \\ 0 & 0 & 0 & 234 \\ 0 & 0 & 0 & 238 \\ 7112 & 1883 & 896 & 2368 \\ 0 & 0 & 0 & 2977 \\ 0 & 0 & 0 & 766\end{array}$

$\begin{array}{rrrrrrrrr}94 & 94 & 94 & 94 & 94 & 94 & 94 & 94 & 94 \\ 321 & 349 & 406 & 264 & 264 & 292 & 349 & 406 & 236 \\ 234 & 234 & 234 & 234 & 234 & 234 & 234 & 234 & 234 \\ 238 & 238 & 238 & 238 & 238 & 238 & 238 & 238 & 238 \\ 1405 & 1405 & 1405 & 1405 & 1405 & 1405 & 1405 & 1405 & 1405 \\ 2977 & 2977 & 2977 & 2977 & 2977 & 2977 & 2977 & 2977 & 2977 \\ 766 & 178 & 778 & 780 & 778 & 778 & 778 & 778 & 778\end{array}$

$\begin{array}{rrrrrr}94 & 0 & 0 & 942 & . & 0 \\ 236 & 0 & 0 & 8323 & \ddots & 2 \\ 234 & 0 & 0 & 2337 & 1 \\ 238 & 0 & 0 & 2384 & 1 \\ 1405 & 0 & 0 & 299585 & 17 \\ 777 & 0 & 0 & 29771 & B \\ 78 & 14 & 98 & 7872 & 2\end{array}$


Container

BOX OTHER
Waste Class 20 $\begin{array}{llll}2010 & 20112012 & 2013\end{array}$

\section{CH_tRUH} RH_LLMN_GTCIII RH_LLPH_I RH_LLMH_III RH_LLH_GTCIII RH_LLY_l RH_LLH_III

RH_TRU

RH_TRUY

Total BOX OTHER

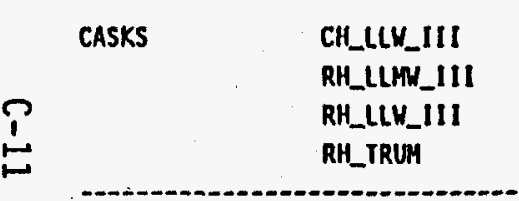

Total CASKS

LEC

\section{CH_LLM_III}

CH_LLY_III

RH_LLFH_III

RH_TRUM

Total LEC

Total OTHER CYL

OTHER DRUMS

CH_LIM_I $\begin{array}{llllllllllll}2014 & 2015 & 2016 & 2017 & 2018 & 2019 & 2020 & 2021 & 2022 & 2023 & \text { HELD } & \text { Total PCt }\end{array}$

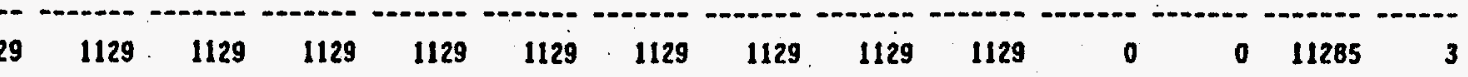

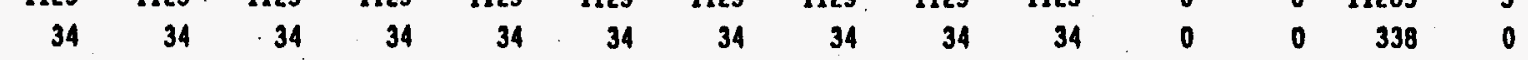

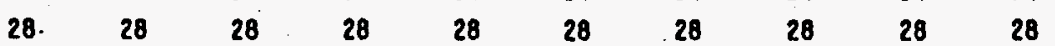

$\begin{array}{llllllllll}73 & 73 & 73 & 73 & 73 & 73 & 73 & 73 & 73 & 73\end{array}$

$106 \quad 106$

$217 \quad 217$

698

$972 \quad 972$

$972 \quad 698$

97297

$287 \quad 287 \quad 287 \quad 287$

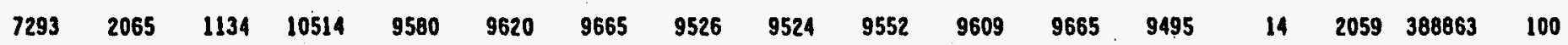

\begin{tabular}{|c|c|c|c|c|c|c|c|c|c|c|c|c|c|c|c|c|}
\hline 0 & 0 & 0 & 0 & 0 & 0 & 0 & 0 & 0 & 0 & 0 & 0 & 0 & 0 & 0 & 170 & 1 \\
\hline 131 & 131 & 131 & 131 & 131 & 131 & 131 & 131 & 131 & 131 & 131 & 131 & 131 & 131 & 1045 & 3658 & 16 \\
\hline 32 & 32 & 32 & 32 & 32 & 32 & 32 & 32 & 32 & 32 & 32 & 32 & 32 & 32 & 0 & 1065 & 5 \\
\hline 0 & 0 & 0 & 0 & 0 & 0 & 0 & 0 & 0 & 0 & 0 & 0 & 0 & 0 & 0 & 18414 & 79 \\
\hline 162 & 162 & 162 & 162 & 162 & 162 & 162 & 162 & 162 & 162 & 162 & 162 & 162 & 162 & 1045 & 23307 & 100 \\
\hline
\end{tabular}

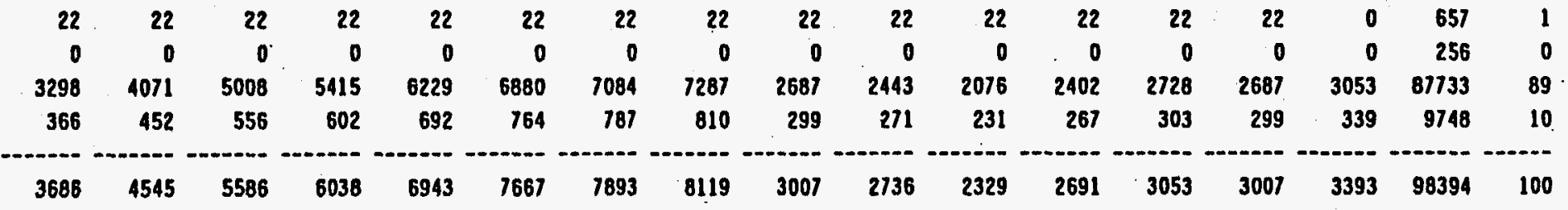

\begin{tabular}{rrrrrrrrrrrrrrrrrr}
0 & 0 & 0 & 0 & 0 & 0 & 0 & 0 & 0 & 0 & 0 & 0 & 0 & 0 & 0 & 2 & 0 \\
0 & 0 & 3 & 0 & 0 & 0 & 0 & 0 & 0 & 0 & 0 & 0 & 0 & 0 & 0 & 3 & 0 \\
2266 & 1416 & 708 & 708 & 0 & 0 & 0 & 0 & 0 & 0 & 0 & 0 & 0 & 0 & 0 & 39943 & 100 \\
\hline 2266 & 1416 & 711 & 708 & 0 & 0 & 0 & 0 & 0 & 0 & 0 & 0 & 0 & 0 & 0 & 39948 & 100
\end{tabular}


(All Volunes In Cubic Meters)

\begin{tabular}{|c|c|c|c|c|c|c|c|c|c|c|c|c|c|c|c|c|c|c|}
\hline Container & Waste Class & 2010 & 2011 & 2012 & 2013 & 2014 & 2015 & 2016 & 2017 & 2018 & 2019 & 2020 & 2021 & 2022 & 2023 & HELD & Total & Pet \\
\hline \multirow{7}{*}{ OTHER DRUMS } & CH_LLH_GTCIII & 2266 & 1416 & 708 & 708 & 0 & 0 & 0 & 0 & 0 & 0 & 0 & 0 & 0 & 0 & 0 & 39943 & 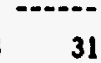 \\
\hline & CH_LLU_I & 0 & 0 & 0 & 4 & 4 & 4 & 4 & 4 & 4 & 4 & 4 & 4 & 4 & 0 & 0 & 40 & \\
\hline & CH_LLY_III & 3966 & 2833 & 1416 & 1416 & 0 & 0 & 0 & 0 & 0 & 0 & 0 & 0 & 0 & 0 & 0 & 89655 & 69 \\
\hline & CH_TRU & 0 & 0 & 0 & 0 & 0 & 0 & 0 & 0 & 0 & 0 & 0 & 0 & 0 & 0 & 0 & 0 & \\
\hline & RH_LLU_I & 0 & 0 & 0 & 4 & 4 & 4 & 4 & 4 & 4 & 4 & 4 & 4 & 4 & 0 & 0 & 44 & \\
\hline & RH_IRU. & 0 & 0 & 0 & 11 & 11 & 11 & 11 & 11 & 11 & 11 & 11 & 11 & 11 & 0 & 1 & 108 & \\
\hline & RH_TRUH & 0 & 0 & 0 & 1 & $\cdots$ & 1 & 1 & 1 & 1 & 1 & 1 & 1 & 1 & 0 & 0 & 6 & \\
\hline
\end{tabular}

$\begin{array}{ll}\text { SWB } & \text { CH_LLY_I } \\ & \text { CH_TRU } \\ & \text { CH_TRUH } \\ & \text { RH_LLMH_GTC111 } \\ & \text { RH_TRU } \\ & \text { RH_TRUH }\end{array}$

Total SWB

$\begin{array}{rrr}0 & 0 & 0 \\ 12 & 12 & 12 \\ 0 & 0 & 0 \\ 0 & 0 & 0 \\ 33 & 36 & 36 \\ 36 & 33 & 36\end{array}$

$\begin{array}{rr}0 & 6 \\ 0 & 34 \\ 0 & 0 \\ 6 & 41 \\ 6 & 36\end{array}$

6
34
0
1
43
33

\begin{tabular}{rrrrr}
6 & 6 & 6 & 6 & 6 \\
34 & 34 & 34 & 34 & 34 \\
9 & 9 & 9 & 9 & 9 \\
1 & 1 & 1 & 1 & 1 \\
129 & 131 & 129 & 41 & 43 \\
122 & 122 & 122 & 36 & 33 \\
\hline 302 & 304 & 302 & 128 & 128
\end{tabular}

\begin{tabular}{rrrrrrr}
6 & 6 & 6 & 0 & 0 & 64 & 2 \\
34 & 34 & 34 & 12 & 9 & 668 & 22 \\
11 & 9 & 9 & 9 & 75 & 176 & 6 \\
1 & 1 & 1 & 0 & 0 & 11 & 0 \\
41 & 42 & 41 & 36 & 277 & 1098 & 36 \\
36 & 36 & 33 & 36 & 279 & 1027 & 34 \\
\hline 30 & 129 & 126 & 93 & 640 & 3046 & 100
\end{tabular}


WHC-EP-0803

APPENDIX D

ANNUAL WASTE CLASS VOLUMES BY CONTAINER TYPES 
WHC-EP-0803

Page Intentionally $\mathrm{Blank}$

D-2 


\begin{tabular}{|c|c|c|c|c|c|c|c|c|c|c|c|c|c|c|c|c|c|}
\hline \multirow{2}{*}{$\begin{array}{l}\text { Vaste Class } \\
\text { CH_LLMH_GTCIII }\end{array}$} & Contalner & 1994 & 1995 & 1996 & 1997 & 1998 & 1999 & 2000 & 2001 & 2002 & 2003 & 2004 & 2005 & 2006 & 2007 & \multicolumn{2}{|c|}{$2008 \quad 2009$} \\
\hline & $4 \times 4 \times 8$ BOX & 0 & 0 & 0 & 0 & 0 & 0 & 0 & 0 & 0 & 0 & 0 & 0 & 0 & 0 & 0 & 0 \\
\hline & 55 GAL DRUH & 2 & 2 & 2 & 33 & 33 & 94 & 48 & 46 & 138 & 168 & 179 & 148 & 205 & 205 & 220 & 220 \\
\hline & BOX OTHER & 0 & 0 & 0 & 0 & 0 & 0 & 0 & 0 & 0 & 0 & 0 & 0 & 0 & 0 & 0 & 0 \\
\hline Total CH_LL & H_GTCIII & 2 & 2 & 2 & 33 & 33 & 94 & 48 & 46 & 138 & 168 & 179 & 148 & 205 & 205 & 220 & 220 \\
\hline CH_LLMH_I & 30 GAL DRUM & 0 & 0 & 0 & 0 & 0 & 0 & 0 & 0 & 0 & 0 & 0 & 0 & 0 & 0 & 0 & 0 \\
\hline & $4 \times 4 \times 8 B 0 \times$ & 466 & 360 & 106 & 367 & 348 & 497 & 1346 & 1346 & 1175 & 511 & 511 & 511 & 511 & 87 & 87 & 87 \\
\hline & 55 GAL ORUM & 908 & 460 & 633 & .3111 & 2626 & 3001 & $2880^{\circ}$ & 3330 & 3400 & 3902 & 4275 & 4505 & 4729 & 4730 & 4722 & 4583 \\
\hline & B-25 BOX & 271 & 541 & 549 & 542 & 539 & 539 & 539 & 0 & 0 & 0 & 0 & 0 & 0 & 0 & 0 & 0 \\
\hline & $80 \times 128-500$ & 20 & 20 & .20 & 20 & 20 & 20 & 20 & 20 & 20 & 20 & 20 & 20 & 20 & 20 & 20. & 20 \\
\hline & $80 \times 500-1000$ & 15 & 0 & 0 & 0 & 0 & . 0 & 0 & 0 & 0 & 0 & 0 & 0 & 0 & 0 & 0 & 0 \\
\hline & $80 X<128$ & 1892 & 321 & 321 & 9 & 6 & 6 & 9 & 6 & 6 & 9 & 6 & 6 & 9 & 6 & 6 & 9 \\
\hline & BOX OTHER & .260 & 326 & 368 & 170 & 170 & 353 & 353 & 353 & 353 & 227 & 227 & 227 & 340 & 340 & 340 & 170 \\
\hline & OTHER CYL & 2 & 0 & 0 & 0 & 0 & 0 & 0 & 0 & 0 & 0 & 0 & 0 & 0 & 0 & 0 & 0 \\
\hline & OTHER ORUMS & 1 & 450 & 0 & 0 & 0 & 0 & 0 & 0 & 0 & 0 & 0 & 0 & 0 & 0 & 0 & 0 \\
\hline Total CH_LL & & 3835 & 2479 & 1997 & 4220 & 3710 & 4417 & 5147 & 5054 & 4954 & 4669 & 5039 & 5269 & 5609 & 5182 & 5175 & 4869 \\
\hline CH_LLMH_III & $4 \times 4 \times 8$ 80X & 73 & 7 & 7 & 7 & 7 & 7 & 7 & 7 & 7 & 7 & 7 & 7 & 7 & 7 & 7 & 11 \\
\hline & 55 GAL DRUM & 29 & 197 & 197 & 224 & 214 & 229 & 224 & 255 & 257 & 265 & 365 & 346 & 423 & 427 & 425 & 447 \\
\hline & BOX 128-500 & 1 & 7 & 7 & 7 & 7 & 7 & 7 & 7 & 7 & 7 & 7 & 7 & 7 & 10 & 19 & 7 \\
\hline & $80 \times 500-1000$ & 0 & 0 & 0 & 0 & 0 & 0 & 0 & 0 & 0 & 0 & 0 & o & 26 & 0 & 0 & 0 \\
\hline & $B 0 X<128$ & 62 & 62 & 62 & 62 & 62 & 0 & 0 & 0 & 0 & 0 & 0 & 0 & 0 & 0 & 0 & 3 \\
\hline & BOX OTHER & 0 & 0 & 0 & 0 & 0 & 0 & 0 & 0 & 0 & 0 & 0 & 0 & 0 & 0 & 0 & 0 \\
\hline & LEC & 22 & 22 & 22 & 22 & 22 & 22 & 22 & 22 & 22 & 22 & 22 & 22 & 22 & 22 & 22 & 22 \\
\hline Total CH_LLI & W_III & 192 & 294 & 294 & 322 & 312 & 265 & 260 & 290 & 293 & 301 & 400 & 382 & 485 & 466 & 473 & 490 \\
\hline CH_LLH_GTCIII & BOX OTHER & 0 & 0 & 0 & 0 & 0 & 0 & 0 & 0 & 0 & 0 & 0 & 0 & 0 & 0 & 0 & 0 \\
\hline & OTHER DRUMS & 0 & 0 & 0 & 0 & 0 & 0 & 0 & 283 & 850 & 1416 & 2550 & 3399 & 5382 & 7365 & 7082 & 65516 \\
\hline
\end{tabular}




\begin{tabular}{ll} 
Haste Class & Contalner \\
\hline Total CH_LLH_GTC11I & \\
& 277 FT3 IOH EX \\
CH_LLH_I & 4X4XB BOX \\
& 55 GAL DRUH \\
& B-25 BOX \\
& BOX 128-500 \\
& BOX $<128$ \\
& BOX $>1000$ \\
& BOX OTHER \\
& OTHER CYL \\
& OTHER ORUHS \\
& SHO
\end{tabular}

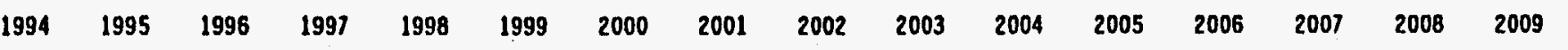

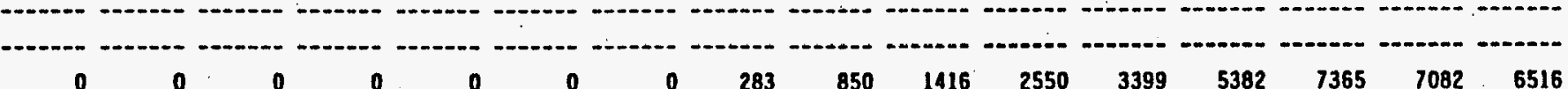

Total CH_LLH_

$\begin{array}{ll}\text { CH_LLH_II } & \text { AX4X8 BOX } \\ & 55 \text { GAL DRUH } \\ & \text { B-25 BOX } \\ \text { BOX } 128-500 \\ \text { BOX } 500-1000 \\ \text { BOX }<128 \\ \text { BOX }>1000 \\ \text { BOX OTHER } \\ \text { CASKS } \\ \text { LEC } \\ \text { OTHER DRUMS }\end{array}$

Total CH_LLH_III

\begin{tabular}{|c|c|c|c|c|c|c|c|c|c|c|c|c|c|c|c|}
\hline 39 & 16 & 22 & 63 & 63 & 63 & 63 & 63 & 63 & 63 & 63 & 63 & 63 & 63 & 63 & 63 \\
\hline 2803 & 3052 & 2551 & 2480 & 2063 & 3133 & 3301 & 5705 & 40030 & 47332 & 78971 & 113296 & 110928 & 129076 & 74664 & 7643 \\
\hline 1331 & 1688 & 1665 & 1546 & 1509 & 4128 & 4041 & 9833 & 14199 & 9454 & 10290 & 13493 & 13102 & 12767 & 8938 & 2677 \\
\hline 875 & 816 & 1382 & 1277 & 543 & 467 & 437 & 182 & 182 & 184 & 164 & 210 & 894 & 877 & 101 & $B 2$ \\
\hline 134 & 418 & 418 & 418 & 418 & 418 & 418 & 418 & 418 & 418 & 418 & 418 & 418 & 10 & 10 & 10 \\
\hline 2946 & 1328 & 624 & 439 & 1518 & 2480 & 1957 & 1714 & 1201 & 563 & 180 & 180 & 180 & 180 & 180 & 180 \\
\hline 326 & 73 & 73 & 73 & 73 & 73 & 73 & 73 & 73 & 73 & 3613 & 3613 & 3613 & 3612 & 3613 & 3614 \\
\hline 122 & 1757 & 1253 & 3230 & 383 & 153 & 7116 & 13446 & 20160 & 31420 & 25157 & 31995 & 43635 & 39988 & 26089 & 28775 \\
\hline 0 & 0 & 0 & 0 & 0 & 0 & 0 & 0 & 0 & 0 & 0 & 0 & 0 & 0 & 0 & . $\quad 0$ \\
\hline 0 & 0 & 0 & 0 & 0 & 0 & 0 & 0 & 0 & 0 & 0 & 0 & 0 & 0 & 0 & 0 \\
\hline 0 & 0 & 0 & 0 & 0 & 0 & 0 & 0 & 0 & 0 & 0 & 0 & 0 & 0 & 0 & 0 \\
\hline
\end{tabular}

$\begin{array}{llllllllllllllllllll}\text { CH_TRU } & 277 \text { FT3 ION EX } & 0 & 71 & 63 & 0 & 0 & 0 & 0 & 0 & 0 & 0 & 0 & 0 & 0 & 0 & 0 & 0 \\ & 4 \times 4 \times B \text { BOX } & 0 & 0 & 0 & 0 & 0 & 0 & 0 & 0 & 0 & 0 & 0 & 0 & 0 & 0 & 0 & 0\end{array}$


(All Volumes In Cublc Meters)

\begin{tabular}{|c|c|c|c|c|c|c|c|c|c|c|c|c|c|c|c|c|c|}
\hline Waste Class & Container & 1994 & 1995 & 1996 & 1997 & 1998 & 1999 & 2000 & 2001 & 2002 & 2003 & 2004 & 2005 & 2006 & 2007 & 2008 & 2009 \\
\hline 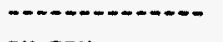 & - & $\cdots+\cdots$ & --.- & $\cdots$ & 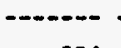 & - & -... & $\cdots$ & $-\cdots$ & - & $\cdots$ & -....... & ....... & $-\cdots+\cdots$ & & & -1 \\
\hline \multirow[t]{6}{*}{ CH_IRU } & 55 GAL ORUH & 143 & 244 & 483 & 284 & 264 & 509 & 650 & 206 & 576 & 698 & 520 & 499 & 499 & 499 & 560 & 560 \\
\hline & $80 \times 128-500$ & 0 & 0 & 0 & 0 & 0 & 0 & 0 & 0 & 0 & 0 & 0 & 0 & 0 & 0 & 0 & 0 \\
\hline & $80 x<128$ & 0 & 0 & 0 & 0 & 0 & 0 & 0 & 0 & 0 & 0 & 0 & 0 & $\mathbf{0}$ & 0 & $\mathbf{0}$ & 0 \\
\hline & BOX OTHER & 0 & 0 . & 0 & 0 & 0 & 0 & 0 & 0 & 0 & $\mathbf{0}$ & 0 & 0 & $\mathbf{0}$ & 0 & 0 & 0 \\
\hline & OTHER DRUMS & 0 & 0 & 0 & 0 & 0 & 0 & 0 & 0 & 0 & 0 & 0 & 0 & 0 & 0 & 0 & 0 \\
\hline & SWB & 20 & 56 & 23 & 16 & 12 & 12 & 12 & 12 & 12 & 12 & 12 & 12 & 12 & 12 & 12 & 12 \\
\hline Total CH_TRU & & 163 & 371 & 569 & 300 & 277 & 521 & 662 & 218 & 588 & 711 & 533 & 512 & 511 & 511 & 512 & 572 \\
\hline
\end{tabular}

\begin{tabular}{|c|c|c|c|c|c|c|c|c|c|c|c|c|c|c|c|c|c|}
\hline CH_IRUM & $4 \times 4 \times 8$ BOX & 0 & 0 & 0 & 0 & 0 & 0 & 0 & 0 & 0 & 0 & 0 & 0 & 0 & 0 & 0 & 0 \\
\hline & 55 GAL DRUH & 6 & 5 & 8 & 4 & 4 & 4 & 60 & 6 & 6 & 6 & 15 & 32 & 117 & 117 & 117 & 117 \\
\hline & BOX OTHER & 0 & 0 & 0 & 0 & 0 & 0 & 0 & 0 & 0 & 0 & 0 & 0 & 0 & 0 & 0 & 0 \\
\hline & SWB & 0 & 11 & 4 & 0 & 0 & 0 & 0 & 0 & 0 & 0 & 0 & 0 & 0 & 0 & 0 & 0 \\
\hline \multicolumn{2}{|c|}{ Total CH_TRUH } & 6 & 17 & 12 & 4 & 4 & 4 & 60 & 6 & 6 & 6 & 15 & 32 & 117 & 117 & 117 & 117 \\
\hline \multirow[t]{4}{*}{ RH_LLMH_GTCIII } & $.4 \times 4 \times 8 B 0 X$ & 0 & 0 & 0 & 0 & 0 & 0 & 0 & 0 & 0 & 0 & 0 & 0 & 0 & 0 & 0 & 0 \\
\hline & 55 GAL DRUM & 0 & 0 & 0 & 0 & 0 & 0 & 0 & 28 & 28 & 28 & 85 & B5 & 142 & 142 & 142 & 142 \\
\hline & BOX OTHER & 0 & 0 & $\mathbf{0}$ & 0 & 0 & 0 & 0 & 0 & 0 & $\mathbf{0}$ & 0 & 0 & 0 & 0 & 0 & 0 \\
\hline & SWB & 0 & 0 & 0 & 0 & 0 & 0 & 0 & 0 & 0 & 0 & 0 & 0 & 0 & 0 & 0 & 0 \\
\hline \multicolumn{2}{|c|}{ Total RH_LLHM_GTCIII } & 0 & 0 & 0 & 0 & 0 & 0 & 0 & 28 & 28 & 28 & 85 & 85 & 142 & 142 & 142 & 142 \\
\hline \multirow[t]{2}{*}{ RH_LLHW_I } & 55 GAL DRUM & 31 & 59 & 61 & 61 & 61 & 61 & 4 & 32 & 32 & 32 & 89 & 89 & 146 & 146 & 146 & 146 \\
\hline & BOX OTHER & 0 & 0 & 0 & 0 & 0 & 0 & 0 & 0 & 0 & 0 & 0 & 0 & 0 & 0 & 0 & 0 \\
\hline \multicolumn{2}{|c|}{ Total RH_LLMH_I } & 31 & 59 & 61 & 61 & 61 & 61 & 4 & 32 & 32 & 32 & 89 & 89 & 146 & 146 & 146 & 146 \\
\hline \multirow[t]{5}{*}{ RH_LLMW_III } & $4 \times 4 \times 880 X$ & 11 & 44 & 29 & 181 & 18 & 0 & 0 & 0 & 0 & 0 & 0 & $0^{-}$ & 0 & 0 & 0 & 0 \\
\hline & 55 GAL DRUH & 0 & 0 & 0 & 0 & 0 & 0 & 0 & 28 & 28 & 28 & 91 & 91 & 147 & 147 & 147 & 147 \\
\hline & $80 \times 128-500$ & 0 & 0 & 0 & 0 & 0 & 0 & 0 & 0 & 0 & 0 & 0 & 0 & 0 & 0 & 5 & 0 \\
\hline & BoX $500-1000$ & 0 & 0 & 0 & 0 & 0 & 0 & 0 & 0 & 0 & 0 & 0 & .0 & 0 & 0 & 51 & 0 \\
\hline & $80 x>1000$ & 0 & 0 & 0 & 0 & 0 & 0 & 0 & 0 & 0 & 0 & 44 & 0 & 0 & 0 & o & 0 \\
\hline
\end{tabular}




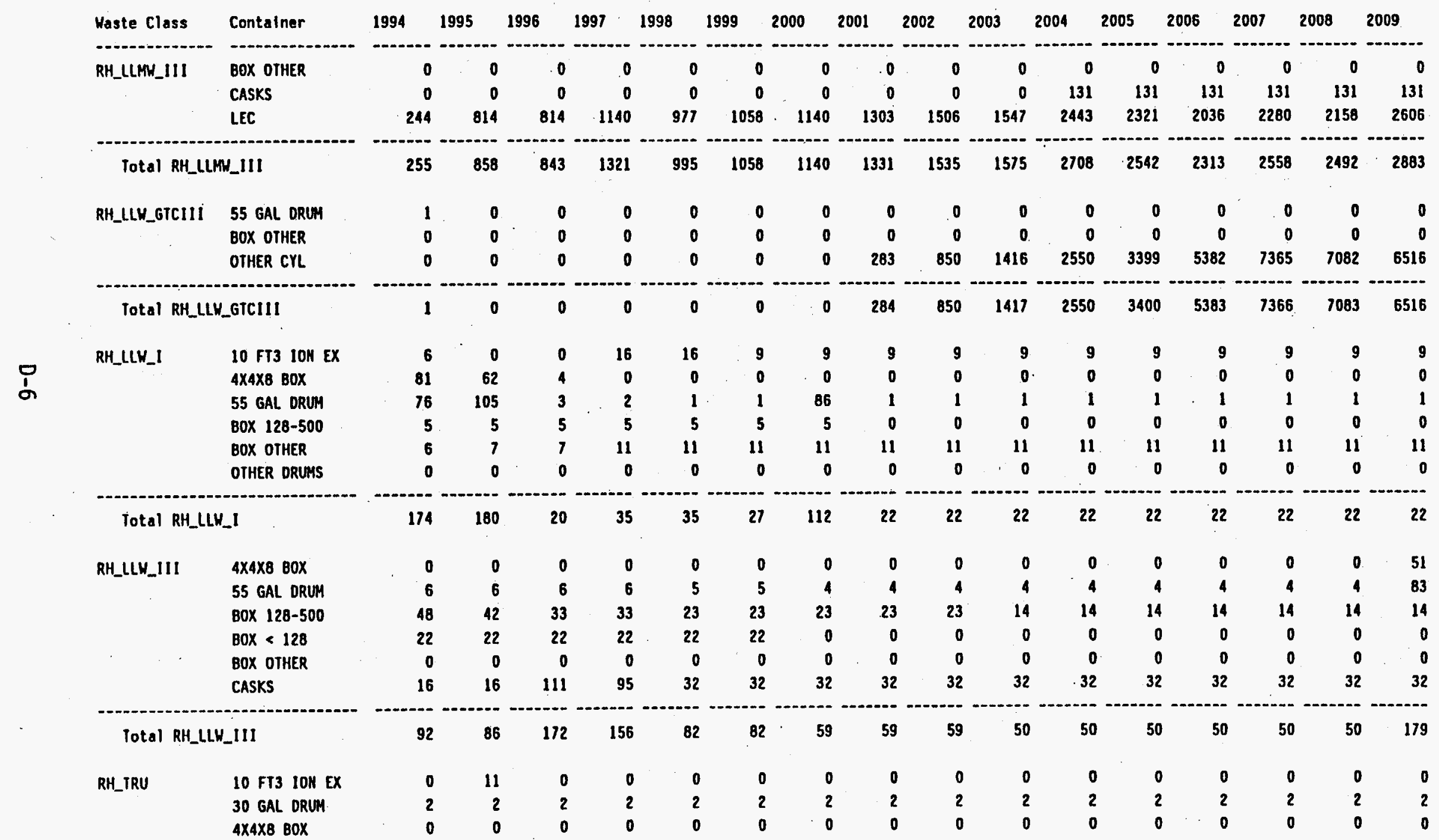


(All Volumes In Cubic Metcrs)

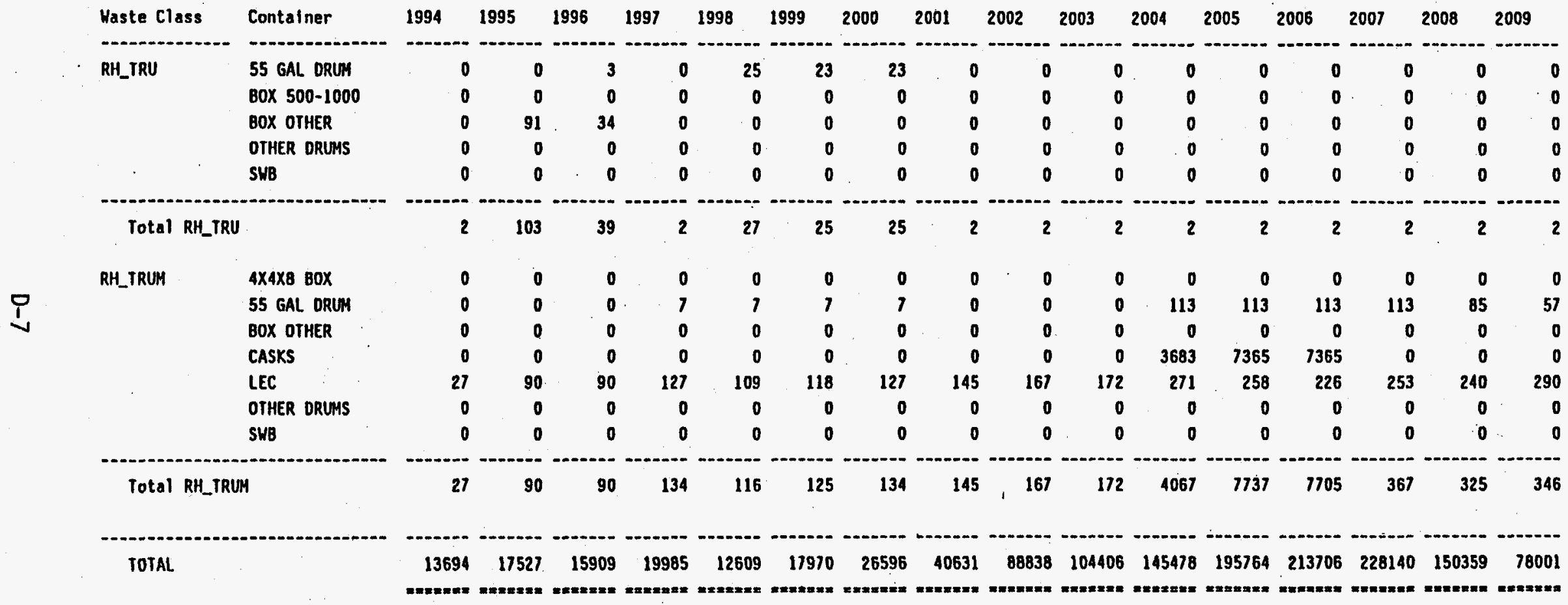


(All Volumes In Cubic Meters)

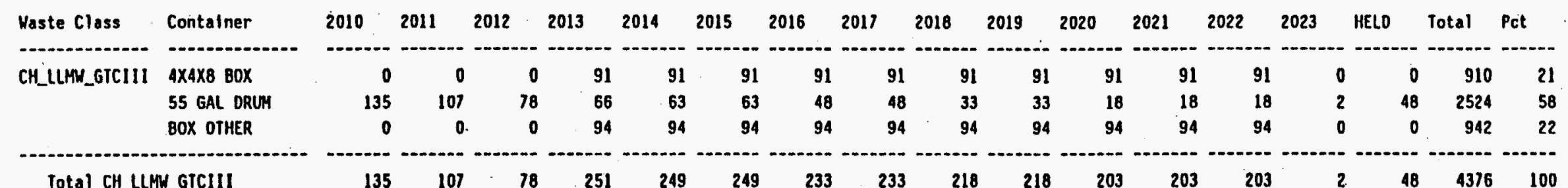

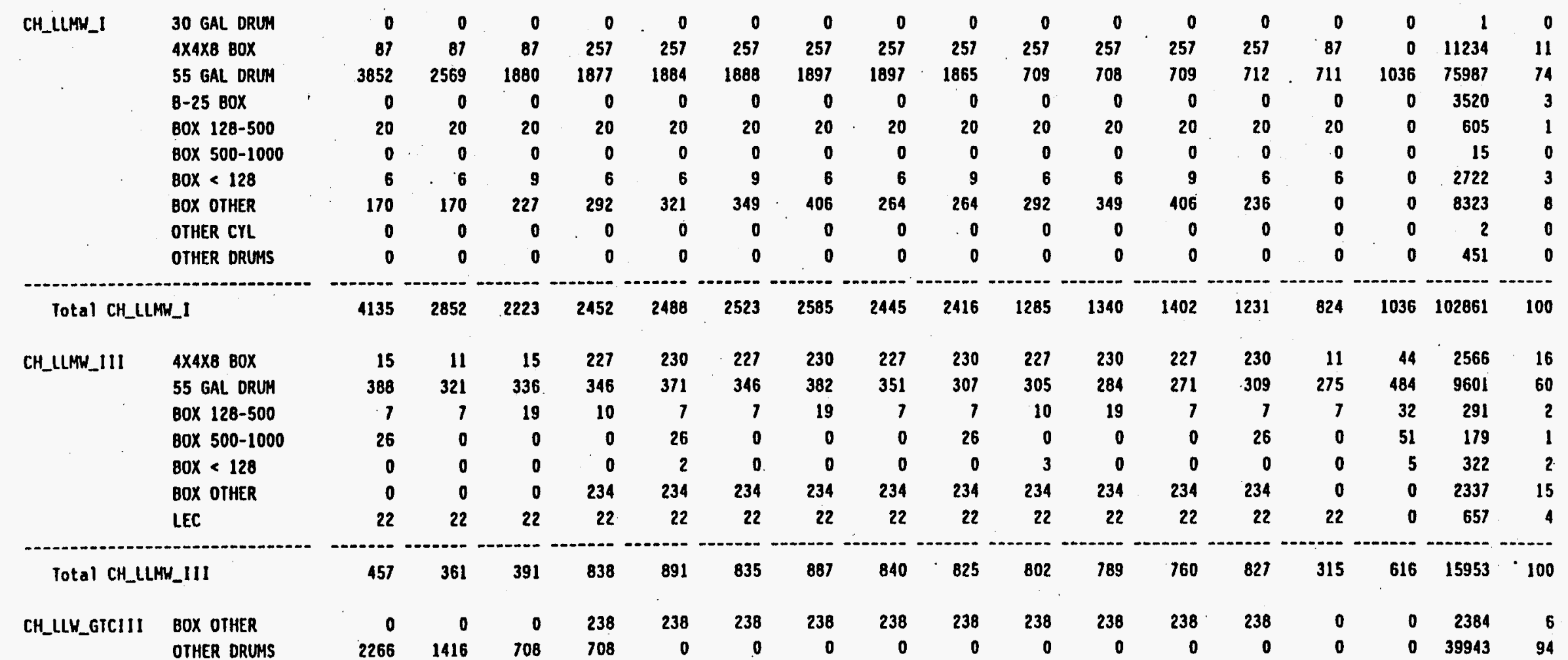




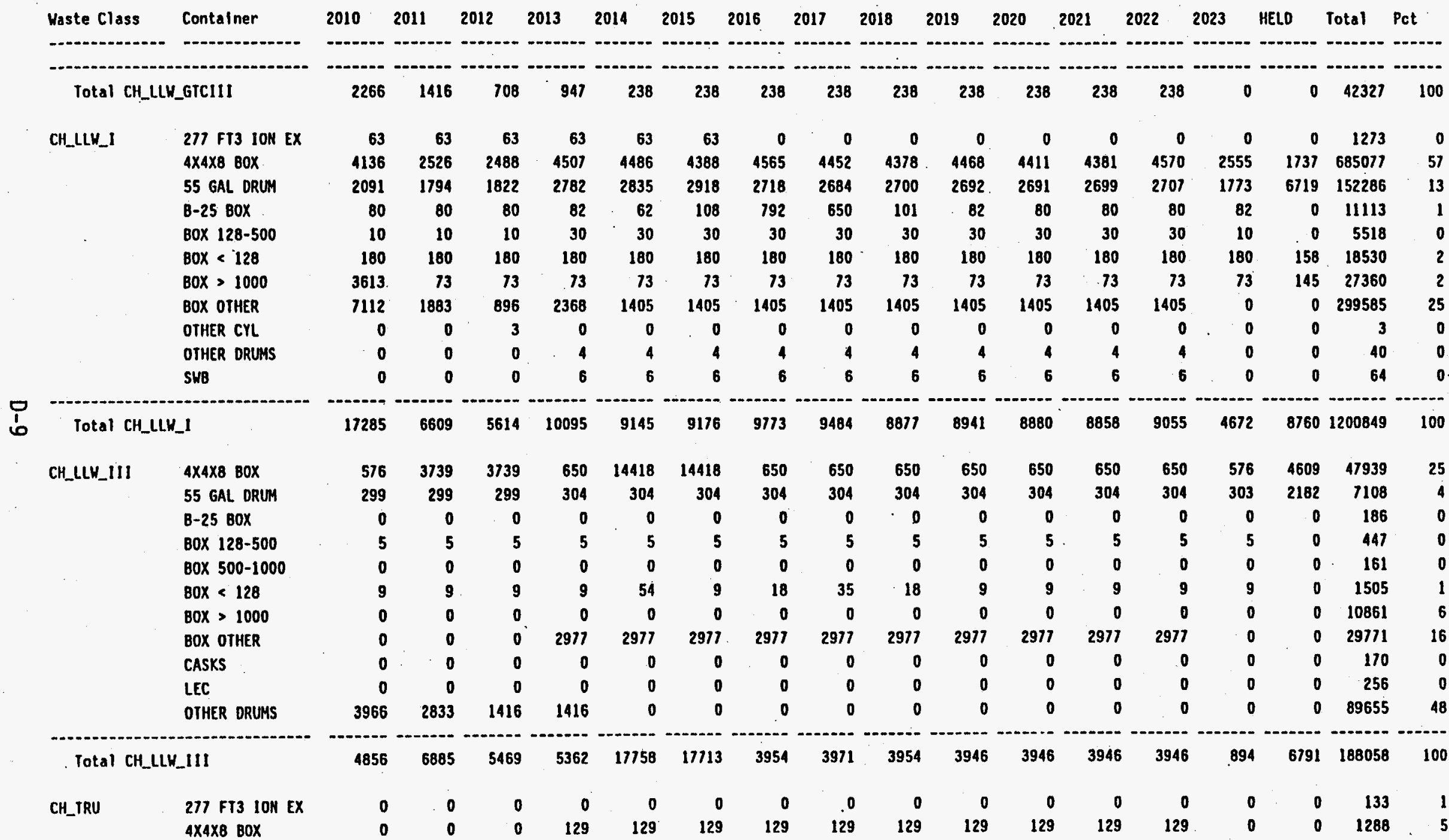


$6 / 15 / 94$

Waste Volumes by Waste $\mathrm{Class}$ and Contalner Type

(All Volumes in Cublc Heters)

\begin{tabular}{|c|c|c|c|c|c|c|c|c|c|c|c|c|c|c|c|c|c|c|}
\hline Haste Class & Contalner & 2010 & 2011 & 2012 & 2013 & 2014 & 2015 & 2016 & 2017 & 2018 & 2019 & 2020 & 2021 & 2022 & 2023 & HELD & Total & Pct \\
\hline - & - & -...... & - & $\ldots$ & - - & -.... & -..... & $\cdots$ & 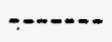 & - & - & -....... & -....... & (4).... & (n).... & & $----\cdots$ & \\
\hline CH_TRU & 55 GAL DRUM & 475 & 475 & 414 & 520 & 491 & 538 & 471 & 477 & 416 & 416 & 355 & 354 & 355 & 187 & 442 & 13584 & 57 \\
\hline & $80 \times 128-500$ & 0 & 0 & 0 & 3 & 3 & 3 & 3 & 3 & 3 & 3 & 3 & 3 & 3 & 0 & 71 & 103 & $\underline{0}$ \\
\hline & $B O X<128$ & 0 & 0 & 0 & 0 & 0 & 0 & 0 & 0 & 0 & 0 & 0 & 0 & 0 & 0 & 2 & 2 & 0 \\
\hline & BOX OTHER & 0 & 0 & 0 & 766 & 166 & 178 & 778 & 780 & 178 & 778 & 178 & 778 & 178 & 14 & 98 & 7872 & 33 \\
\hline & OTHER DRUHS & 0 & 0 & 0 & 0 & 0 & 0 & 0 & 0 & 0 & 0 & 0 & 0 & 0 & 0 & 0 & 0 & 0 \\
\hline & SHB & 12 & 12 & 12 & 34 & 34 & 34 & 34 & 34 & 34 & 34 & 34 & 34 & 34. & 12 & 9 & 668 & 3 \\
\hline - & - & $\cdots$ & 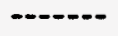 & nas. & (n.... & - & (n..... & $\cdots$ & -.... & $\cdots$ & -...- & $\cdots$ & $-\infty$ & (n) & $-\cdots$ & $\cdots$ & $\cdots-\cdots$ & $\cdots$ \\
\hline Total CH_TRU & & 488 & 487 & 426 & 1452 & 1423 & 1482 & 1421 & 1423 & 1360 & 1360 & 1299 & 1298 & 1299 & 214 & 628 & 23651 & 100 \\
\hline CH_TRUH & $4 \times 4 \times 8$ B0X & 0 & 0 & 0 & 148 & 148 & 148 & 148 & 148 & 148 & 148 & 148 & 148 & 148 & 0 & 0 & 1484 & 10 \\
\hline & 55 GAL ORUM & 32 & 32 & 32 & 32 & 3 & 53 & 53 & 53 & 53 & 53 & 53 & 53 & 53 & 53 & 398 & 1624 & 11 \\
\hline & BOX OTHER & 0 & 0 & 0 & 1129 & 1129 & 1129 & 1129 & 1129 & 1129 & 1129 & 1129 & 1129 & 1129 & 0 & 0 & 11285 & 77 \\
\hline & SWB & 0 & 0 & 0 & 0 & 0 & 9 & 9 & 9 & 9 & 9 & 11 & 9 & 9 & 9 & 75 & 176 & 1 \\
\hline Total CH_TRU & $M$ & 32 & 32 & 32 & 1309 & 1281 & 1339 & 1339 & 1339 & 1339 & 1339 & 1341 & 1339 & 1339 & 62 & 473 & 14569 & 100 \\
\hline RH_LLMH_GTCIII & $4 \times 4 \times 8 B 0 X$ & 0 & 0 & $\mathbf{0}$ & 23 & 23 & 23 & 23 & 23 & 23 & 23 & 23 & 23 & 23 & 0 & 0 & 232 & 15 \\
\hline & 55 GAL DRUM & 57 & 28 & 14 & 6 & 4 & 4 & 4 & 4 & 4 & 4 & 4 & 4 & 4 & 0 & 14 & 973 & 63 \\
\hline & BOX OTHER & 0 & 0 & 0 & 34 & 34 & 34 & 34 & 34 & 34 & 34 & 34 & 34 & 34 & 0 & 0 & 338 & 22 \\
\hline & SWB & 0 & 0 & o & 1 & 1 & 1 & 1 & 1 & 1 & 1 & 1 & 1 & 1 & 0 & 0 & 11 & 1 \\
\hline Total RH_LLM & H_GTCIII & 57 & 28 & 14 & 64 & 62 & 62 & 62 & 62 & 62 & 62 & 62 & 62 & 62 & 0 & 14 & 1554 & 100 \\
\hline RH_LLMH_I & 55 GAL DRUM & 61 & 32 & 18 & .7 & 4 & 4 & 4 & 4 & 4 & 4 & 4 & 4 & 4 & 4 & 0 & 1357 & 72 \\
\hline & BOX OTHER & 0 & 0 & 0 & 28 & 28 & 28 & 28 & 28 & 28 & 28 & 28 & 28 & 28 & 0 & 242 & 520 & 28 \\
\hline Total RH_LLH & & 61 & 32 & 18 & 35 & 32 & 32 & 32 & 32 & 32 & 32 & 32 & 32 & 32. & 4 & 242 & 1877 & 100 \\
\hline RH_LLMH_III & $4 \times 4 \times 880 X$ & 0 & 0 & 0 & 45 & 45 & 45 & 45 & 45 & 45 & 45 & 45 & 45 & 45 & 0 & 0 & 736 & 1 \\
\hline & 55 GAL DRUM & 62 & 34 & 20 & 8 & 6 & 6 & 6 & 6 & 6 & 6 & 6 & 6 & 6 & 6 & 45 & 1081 & 1 \\
\hline & $80 \times 128-500$ & 4 & 0 & 5 & 0 & 0 & 0 & 9 & 0 & 0 & 0 & 5 & 0 & 4 & 0 & 14 & 44 & 0 \\
\hline & $80 \times 500-1000$ & 0 & 0 & 51 & 0 & 0 & 0 & 51 & 0 & 0 & 0 & 51 & 0 & 0 & 0 & 102 & 306 & 0 \\
\hline & $\mathrm{BOX}>1000$ & 0 & 0 & 0 & 0 & 44 & 0 & 0 & 0 & 0 & 0 & 0 & 0 & 0 & 0 & 44 & 132 & 0 \\
\hline
\end{tabular}




\begin{tabular}{ll} 
Haste Class & Container \\
\hdashline RH_LLM_III & $\begin{array}{l}\text { BOX OTHER } \\
\text { CASKS } \\
\text { LEC }\end{array}$ \\
\hdashline
\end{tabular}

\begin{tabular}{rrrrrrrrrrrrrrrrr}
2010 & 2011 & 2012 & 2013 & 2014 & 2015 & 2016 & 2017 & 2018 & 2019 & 2020 & 2021 & 2022 & 2023 & HELD & Total & Pct \\
0 & 0 & 0 & 73 & 73 & 73 & 73 & 73 & 73 & 73 & 73 & 73 & 73 & 0 & 0 & 734 & 1 \\
131 & 131 & 131 & 131 & 131 & 131 & 131 & 131 & 131 & 131 & 131 & 131 & 131 & 131 & 1045 & 3658 & 4 \\
3298 & 1071 & 5008 & 5415 & 6229 & 6880 & 7084 & 7287 & 2687 & 2443 & 2076 & 2402 & 2728 & 2687 & 3053 & 87733 & 93 \\
\hline 3494 & 4236 & 5214 & 5672 & 6528 & 7135 & 7398 & 7542 & 2942 & 2698 & 2381 & 2651 & 2986 & 2823 & 4303 & 94425 & 100
\end{tabular}

Total RH_LLHW_III

RH_LLH_GTCIII 55 GAL ORUM BOX OTHER OTHER CYL

\section{Total RH_LLH_GTCIII}

$\begin{array}{ll} & 10 \text { FT3 ION EX } \\ & \text { RXALE BOX } \\ & 55 \text { GAL DRUH } \\ & \text { BOX 128-500 } \\ & \text { BOX OTHER } \\ & \text { OTHER DRUMS }\end{array}$

Total RH_LLH_I

\begin{tabular}{|l|l} 
RH_LLYIII & 4Xं4XB BOX \\
& 55 GAL DRUM \\
& BOX 128-500 \\
& BOX $<128$ \\
& BOX OTHER \\
CASKS
\end{tabular}

Total RH_LLH_III

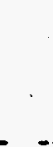

\begin{tabular}{rrrrrrrrrrrrrrrrr}
0 & 0 & 0 & 0 & 0 & 0 & 0 & 0 & 0 & 0 & 0 & 0 & 0 & 0 & 24 & 33 & 0 \\
0 & 0 & 0 & 106 & 106 & 106 & 106 & 106 & 106 & 106 & 106 & 106 & 106 & 0 & 0 & 1059 & 3 \\
2266 & 1416 & 708 & 708 & 0 & 0 & 0 & 0 & 0 & 0 & 0 & 0 & 0 & 0 & 0 & 39943 & 97 \\
\hline 2267 & 1417 & 709 & 814 & 106 & 106 & 106 & 106 & 106 & 106 & 106 & 106 & 106 & 0 & 24 & 41035 & 100
\end{tabular}

$\begin{array}{cc}9 & 9 \\ 0 & 0 \\ 1 & 1 \\ 0 & 0 \\ 11 & 11 \\ 0 & 0\end{array}$

$\begin{array}{rr}9 & \\ 0 & 1 \\ 1 & \\ 0 & \\ 11 & 217 \\ 0 & 4\end{array}$

$\begin{array}{rr}9 & \\ 147 & 147 \\ 8 & \\ 21 & 21 \\ 217 & 217 \\ 4 & \end{array}$

\begin{tabular}{rr}
9 & \\
147 & 147 \\
8 & \\
21 & 21 \\
217 & 217 \\
4 & \\
\hdashline-7 &
\end{tabular}

\begin{tabular}{rrr}
9 & 0 \\
147 & 147 & 147 \\
8 & 6 & \\
21 & 21 & \\
217 & 205 & 205 \\
4 & 1 & \\
\hline 406 & 385 & 385
\end{tabular}

$\begin{array}{r}106 \\ 0 \\ 147 \\ 8 \\ 21 \\ 205 \\ 4 \\ \hline-2\end{array}$

\begin{tabular}{rr}
0 & \\
147 & 147 \\
8 & \\
21 & 21 \\
205 & 205 \\
4 & \\
\hline 385 & 385
\end{tabular}

$\begin{array}{rrrrrrr}22 & 22 & 22 & 406 & 406 & 406 & 385 \\ 51 & 51 & 55 & 715 & 715 & 715 & 719 \\ 83 & 83 & 83 & 83 & 83 & 83 & 83 \\ 14 & 14 & 14 & 14 & 14 & 14 & 14 \\ 0 & 0 & 0 & 0 & 0 & 0 & \\ 0 & 0 & 0 & 698 & 698 & 698 & 698 \\ 32 & 32 & 32 & 32 & 32 & 32 & 32\end{array}$

\begin{tabular}{rr}
0 & \\
147 & 147 \\
21 & \\
205 & 205 \\
4 & \\
\hdashline & \\
385 & 3
\end{tabular}

$\begin{array}{rr}147 & 147 \\ 21 & \\ 205 & 205 \\ 4 & \\ 4 & \\ 385 & 385\end{array}$

\begin{tabular}{|c|c|c|c|c|}
\hline 0 & 0 & 0 & 193 & 3 \\
\hline 147 & 0 & 0 & 1615 & 28 \\
\hline 8 & 1 & 0 & 368 & 6 \\
\hline 21 & 0 & 0 & 251 & 4 \\
\hline 205 & 0 & 1022 & 3310 & 57 \\
\hline 4 & 0 & 0 & 44 & 1 \\
\hline
\end{tabular}

RH_TRU

\begin{abstract}
IO FT3 ION EX 30 GAL DRUM 4X4XB BOX
\end{abstract}

\begin{tabular}{rrrrrrrrrrr}
915 & 715 & 715 & 719 & 715 & 715 & 51 & 415 & 7831 & 42 \\
0 & 83 & 83 & 83 & 83 & 83 & 83 & 83 & 629 & 1943 & 10 \\
& 14 & 14 & 14 & 14 & 14 & 14 & 14 & 0 & 555 & 3 \\
& 0 & 0 & 0 & 0 & 0 & 0 & 0 & 0 & 130 & 1 \\
& 698 & 698 & 698 & 698 & 698 & 698 & 0 & 0 & 6984 & 38 \\
& 32 & 32 & 32 & 32 & 32 & 32 & 32 & 0 & 1065 & 6 \\
\hline 1541 & 1541 & 1541 & 1545 & 1541 & 1541 & 179 & 1044 & 18509 & 100
\end{tabular}

$$
\begin{array}{r}
0 \\
2 \\
32
\end{array}
$$

0.

0
2
32

\footnotetext{
.
} 
$6 / 15 / 94$

Maste Class

RH_IRU

Container

55 GAL DRUH

BOX 500-1000

BOX OTHER

OTHER ORUMS

SWB

Total RH_TRU

$\stackrel{?}{\stackrel{\leftrightarrow}{*}}$

$\begin{array}{ll}\text { RH_IRUM } & \text { 4X4X8. BOX } \\ & 55 \text { GAL DRUM } \\ & \text { 60X OTHER } \\ & \text { CASKS } \\ & \text { LEC } \\ \text { OTHER ORUMS } \\ \text { SWB }\end{array}$

Total RH_TRUM
2010

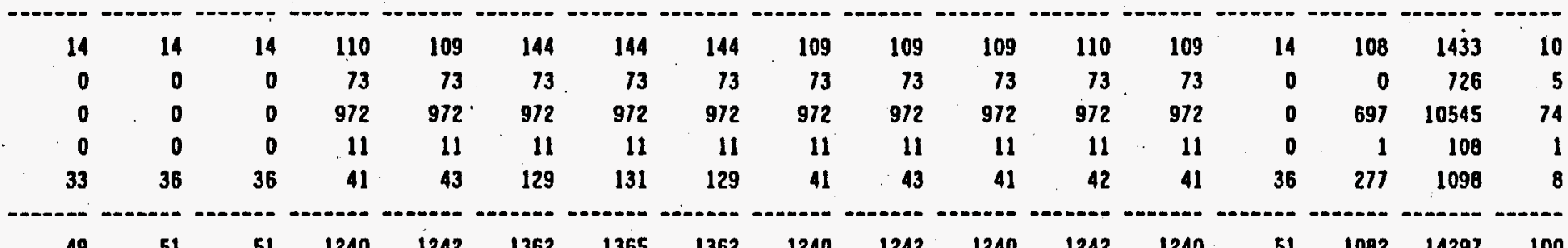

$\begin{array}{rrr}0 & 0 & 0 \\ 42 & 42 & 42 \\ 0 & 0 & 0 \\ 0 & 0 & 0 \\ 366 & 452 & 556 \\ 0 & 0 & 0 \\ 36 & 33 & 36\end{array}$

Waste Volumes by Haste Class and Container Type

(All Volumes in Cubic Meters) 
WHC-EP-0803

\section{APPENDIX E}

WASTE GENERATOR CONTAINER TYPE VOLUMES BY WASTE CLASS 
WHC-EP-0803

Page Intentionally $\mathrm{Blank}$ 
$6 / 27 / 94$

Waste Generator Contalner Category CH_LLm_GTC1II (n..................

AMES

4X4X8 BOX
55 GAL DRUM
OTHER DRUMS

Total for AMES

ANL_E

$$
\begin{aligned}
& 30 \text { GRL DRUM } \\
& 55 \text { OAL DRUM }
\end{aligned}
$$
BOX $<120$

Total for ANL_E

w

BAPL

55 GAL DRUM
B-25 BOX
CASKS
OTHER CYL

Total for BAPr

BAPL_SHIPYDS

BOX $128-500$ OTHER CXL

Total for BAPL_SHIPYDS

BAT_CLBS_LAB

55 GAL DRUM

B-25 BOX

Total for BAT_CLES_LAB

0
0
0
0

0
0
0

....

0
0
0
4X4X8 BOX

55 GAL DRUM
Haste Class Volumes $\left(\mathrm{m}^{\wedge} 3\right)$ by

Container Category and Maste Generator
H_LEM_I

CH_LLMH_III (2...........

CH_LLH_GTCII I.

CH_LLH_I

CH_LLH_III

CH_TRU CH_TRUM RH_LLMH_GTCIII

RH_LLMH_I RH_LLMH_III

236
1
0
-

0
0
0
0

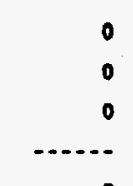

$\begin{array}{r}0 \\ 411 \\ 2519 \\ \hline\end{array}$

0
0
0
0

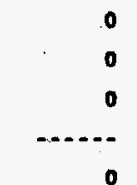

$\begin{array}{rr}31 & 0 \\ 5 & 0 \\ 0 & 0 \\ 2 & 0 \\ 3 & 0\end{array}$

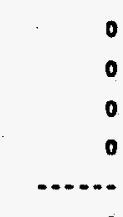

0

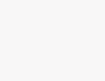

r...-

.....

47
0
$-\ldots .+$

47

0
136
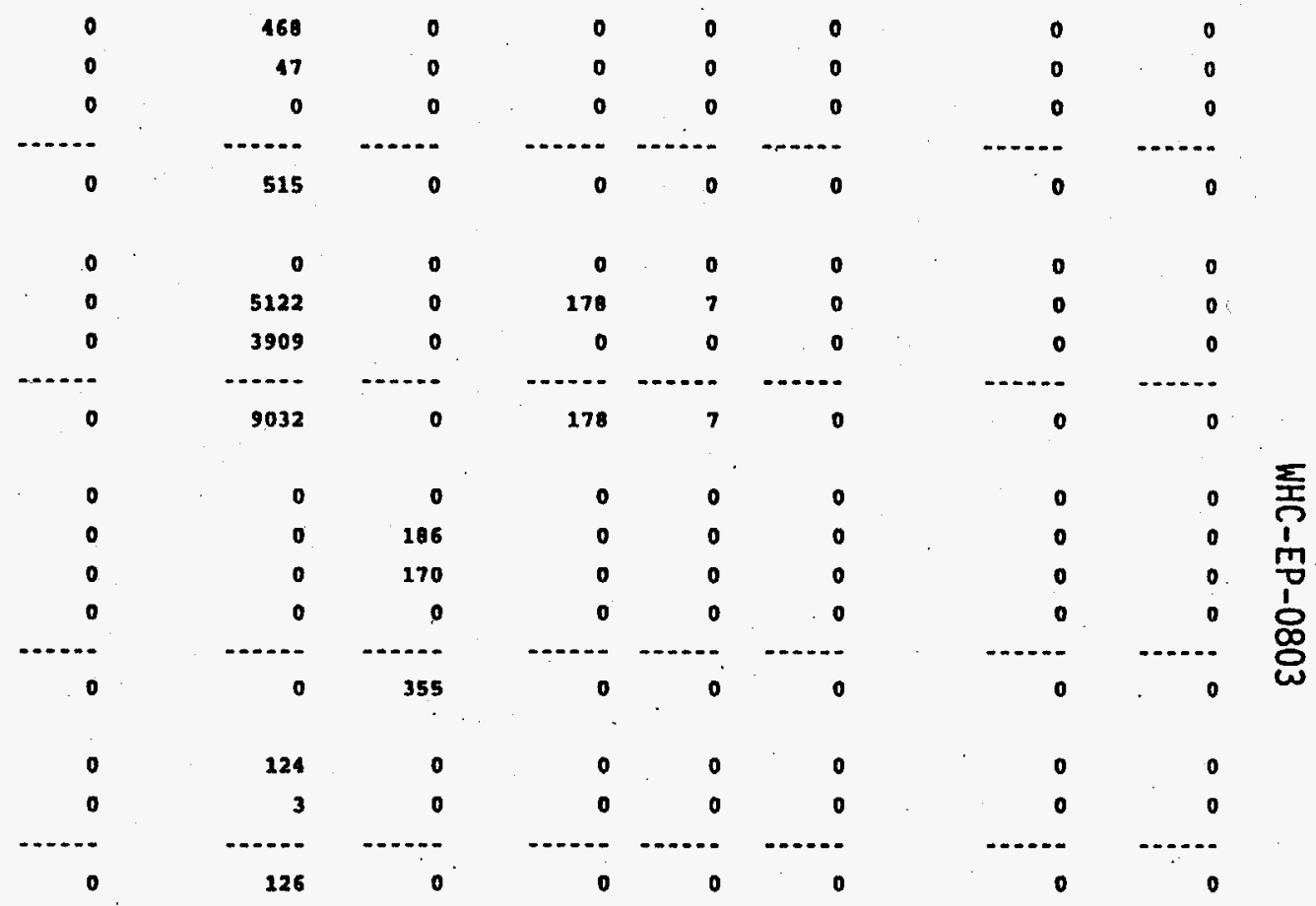

0
0
0

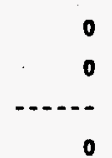

0
2772
$\ldots$

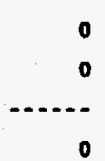

$\begin{array}{rrr}0 & 0 & 0 \\ 0 & 0 & 0 \\ 0 & 0 & 0\end{array}$

$\begin{array}{rr}0 & 0 \\ 0 & 0 \\ 0 & 0\end{array}$

11164

2952

o

0


$6 / 27 / 94$.

Haste Class Volumes $\left(\mathrm{m}^{\wedge} \mathrm{3}\right)$ by

Container Category and Maste Generator

Haste Generator Container Category CH_LLM_GTCrII CH_LLM_I CH_LLMH_III CH_LLH_OTCIII CH_LLH_I CY

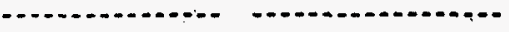

Total for BRKHW

B_LEHR_dNV

55 GAL DRUM

B-25 Box

TOtal for B_LEHR_DAV

EGEG

55 GAL DRUM

BOX $<128$

$\prod_{1}$ Total for EOLG

BOX $<128$

Total for FERMI

EUSRAP

\section{$4 \times 4 \times 8$ Box}

$B 0 X>1000$

Total for FUSRAP

GEN_ATOM

4X4X8 BOX

55 GAL DRUM BOX $<128$

Total for GEN_ATOM

KAPL_SHIPYDS

BOX $128-500$

BOX 500-1000

LEC
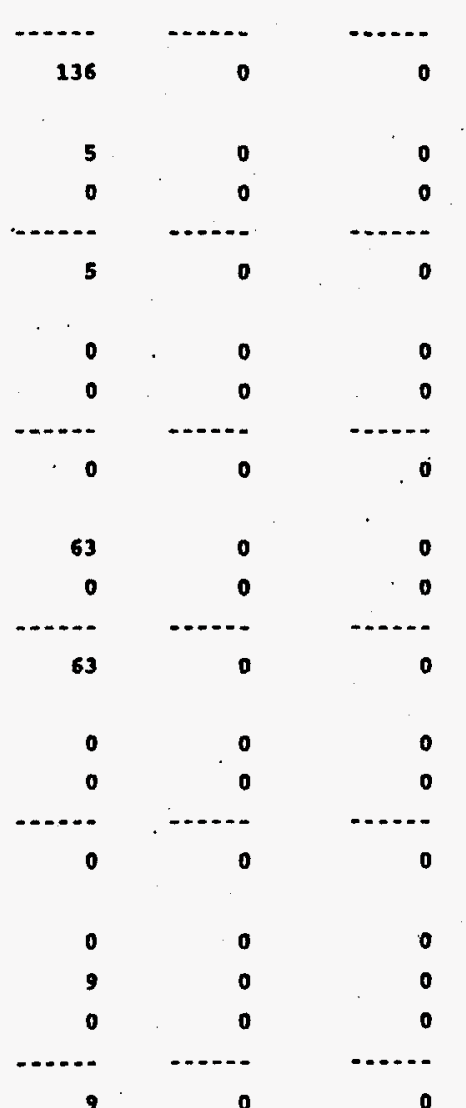

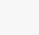

0
-........

LLLH_III

CH TRU CH_TRUM RH_LLM OTCIII

RH_LLMH_I. RH_LLMH_III
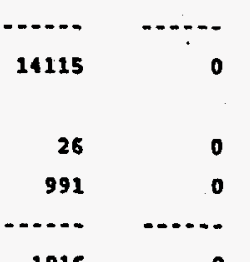

1016

$\begin{array}{rr}131 & 0 \\ 156 & 0 \\ 286 & 0\end{array}$

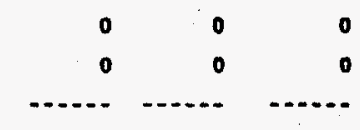

$\begin{array}{rr}175 & 0 \\ 1016 & 0 \\ 1 & 0\end{array}$

1191

12728
0

12728

33861
10861

....... .

44722

\begin{tabular}{rr}
164 & 0 \\
0 & 0 \\
359 & 0 \\
\hdashline .0 & 0
\end{tabular}
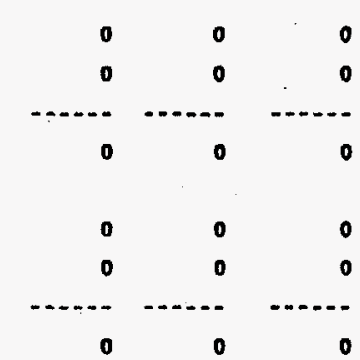

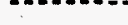

RLLN"
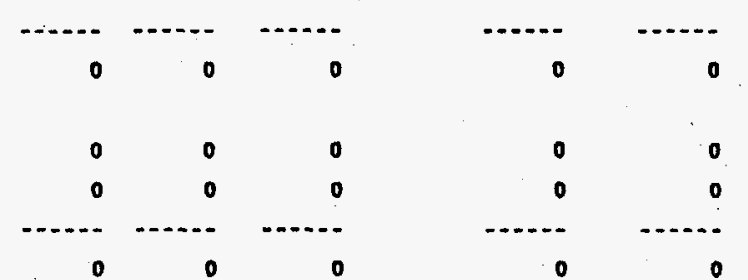

523

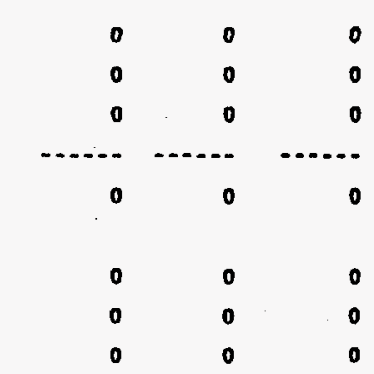

$\begin{array}{llllll}216 & 0 & 0 & 0 & 0 & 0 \\ 161 & 0 & 0 & 0 & 0 & 0 \\ 256 & 0 & 0 & 0 & 0 & 0\end{array}$




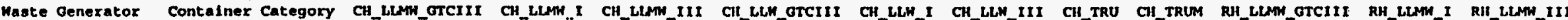

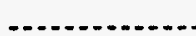

Total for KAPL_SHIPYDS

KEH_100

55 ORL DRUM

Total for KBH_100

LEL

55 OAL DRUM

BOX $<228$

Total for Lat

LLNE

$\begin{array}{ll}\text { WLNL } & 55 \text { GAL DRUM } \\ \text { í } & \text { BOX }<128 \\ & \text { BOX }>1000 \\ & \text { SWB }\end{array}$

Total for LLNL

LL_EQUIP

LEC

Tota1 for LL_EQUIP

LL_EQUIP_SEC

4XAX8 BOX

55 GAL DRUM

Total for. LL_EQUIP_SEC

MIT_BATES 55 GAL DRUM

Total for MIT_BATES

PADUCAH_ES 55 GAL DRUM
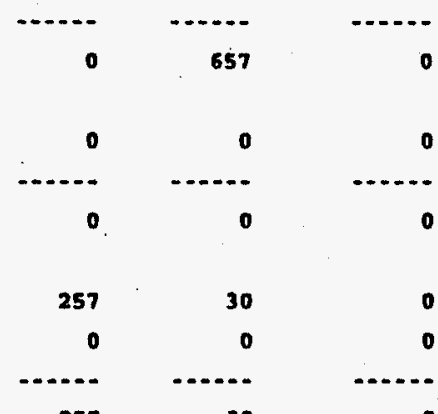

$\begin{array}{rr}629 & 0 \\ 0 & 0 \\ 0 & 0 \\ 0 & 0 \\ 629 & 0\end{array}$

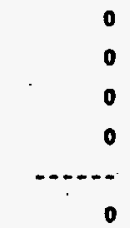

$\begin{array}{rr}0 & 0 \\ 0 & 0\end{array}$

0
0

$\begin{array}{rr}0 & 0 \\ 476 & 1158 \\ -2 . & \end{array}$

176

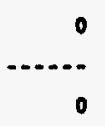

o

2620
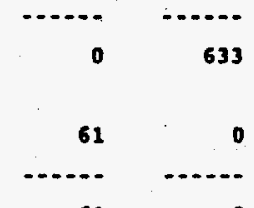

0
0
0

\begin{tabular}{rr}
553 & 88 \\
9049 & 990 \\
\hline$\ldots .$. & $-\ldots$. \\
\hline 96
\end{tabular}

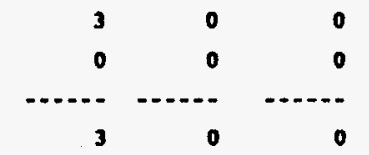

\begin{tabular}{rr}
1962 & 0 \\
2614 & 0 \\
2324 & 0 \\
0 & 0 \\
\hdashline 6900 & 0
\end{tabular}

\begin{tabular}{rrr}
654 & 31 & 0 \\
0 & 0 & 0 \\
0 & 0 & 0 \\
122 & 0 & 0 \\
\hline 776 & 31 & 0
\end{tabular}
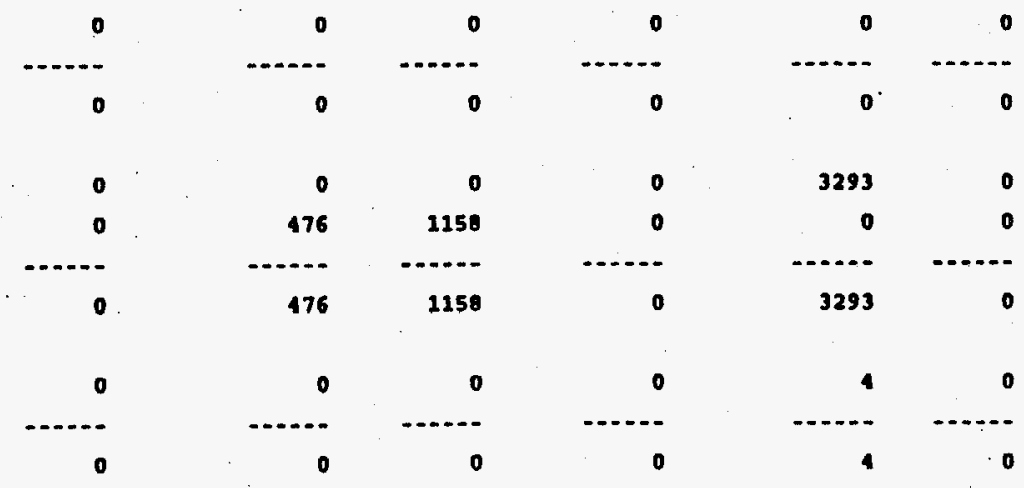

o \begin{tabular}{rr}
3293 & 0 \\
0 & 0 \\
\hline 3293 &...-
\end{tabular}

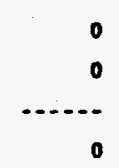

3293
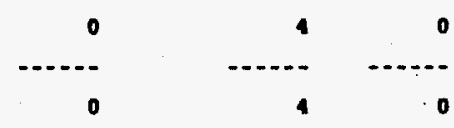

44854
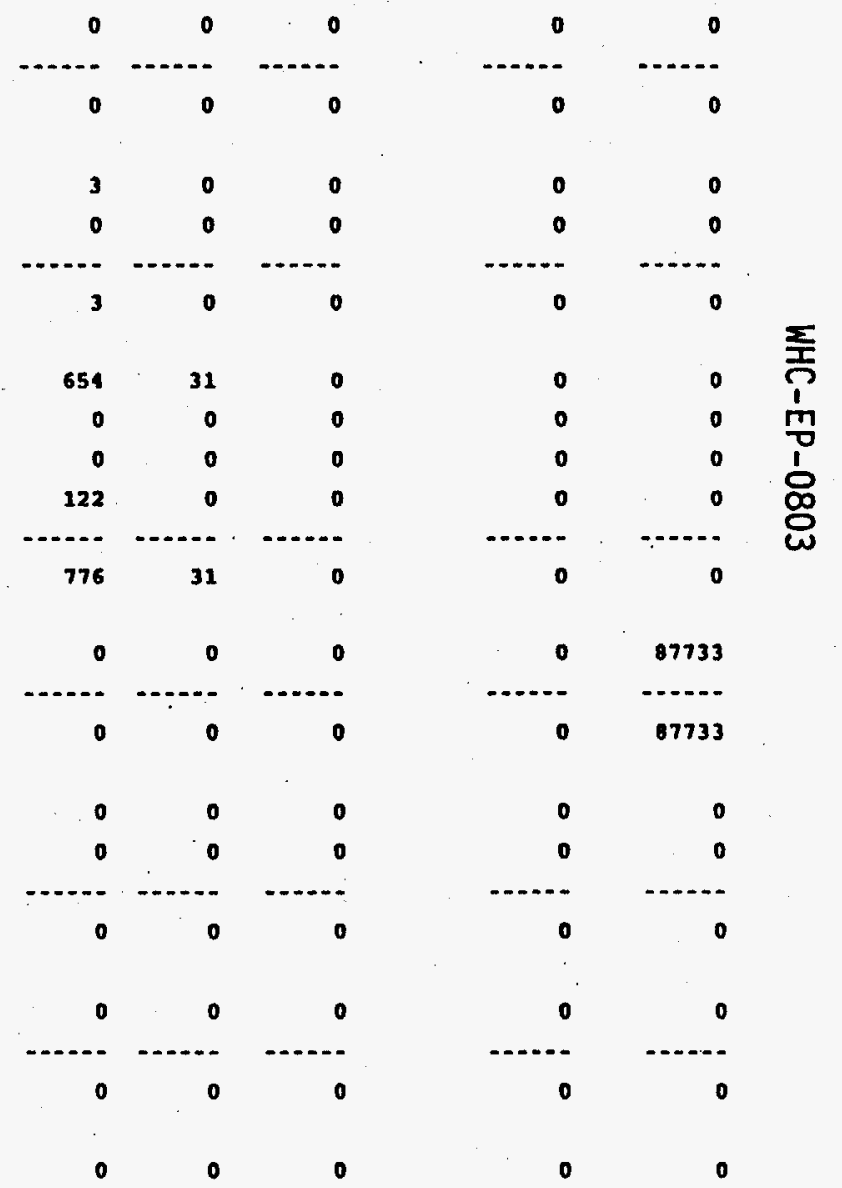
$6 / 27 / 94$

Waste Class Volurnes $\left(m^{\wedge} 3\right)$ by

Contalner Category and waste Generator

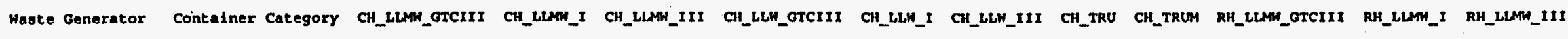

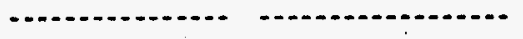

PADUCAH_ES BOX $<120$

Total for PADUCAH_ES

PADUCAH_U 55 OAL DRUM

Total for PADUCAH_U

PAST_PRAC_REM 55 GAL DRUM

Total for PAST_PRAC_REM

mon

PNL

$4 \times 4 \times 8$ BOX
55 GAL DRUM
BOX $128-500$
BOX $<128$
OTHER DRUMS

Total for PNL

PORTSMOUTH

55 GAL DRTM

B-25 BOX

Box 128-500

OTHER DRUMS

TOtal for PORTSMOUTH

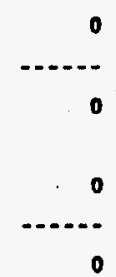

262

$\begin{array}{r}308 \\ \therefore-2 . \\ \hline 308\end{array}$

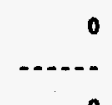

64

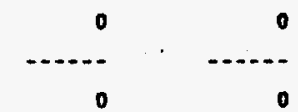

1484

1778

$\begin{array}{rr}520 & 0 \\ 520 & 0\end{array}$

1484

4778

0
14
0
0
0
14

$\begin{array}{rrr}0 & 0 & 0 \\ 221 & 0 & 0 \\ 0 & 190 & 0 \\ 0 & 0 & 0 \\ 0 & 0 & 0 \\ 222 & 198 & \cdots\end{array}$

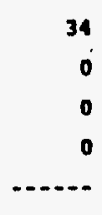

34

\begin{tabular}{rr}
17426 & 11 \\
3512 & 0 \\
0 & 0 \\
450 & 0 \\
\hline 21398 & 11
\end{tabular}

PRINCETON

55 GNL DRUM
B-25 BOX

$80 x<128$

Total for PRINCETON

0
0
0
0

$\begin{array}{rrr}57 & 0 & 0 \\ 0 & 0 & 0 \\ 0 & 0 & 0 \\ 57 & 0 & 0\end{array}$
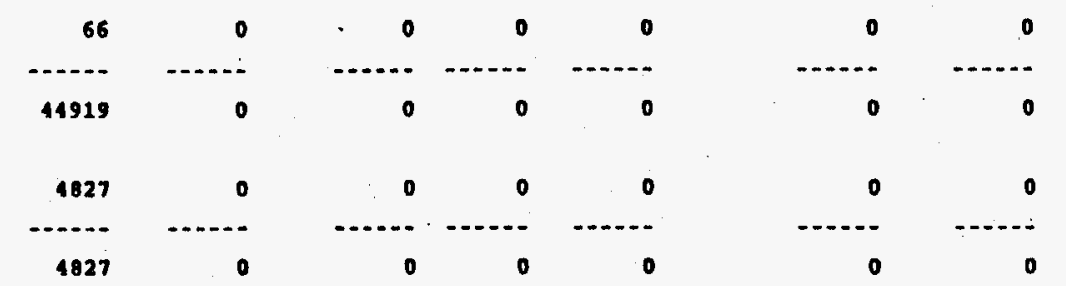

$\begin{array}{cc}0 & 0 \\ 0 & 0\end{array}$

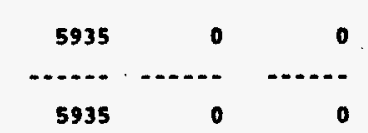

\begin{tabular}{rr}
10462 & 0 \\
1719 & 39 \\
0 & 192 \\
0 & 0 \\
0 & 0 \\
\hdashline 12181 & 231
\end{tabular}

$\begin{array}{rrr}0 & 0 & 0 \\ 32 & 1 & 14 \\ 77 & 0 & 0 \\ 2 & 0 & 0 \\ 0 & 0 & 0 \\ 111 & 1 & 14\end{array}$

$\begin{array}{rr}0 & 0 \\ 0 & 0\end{array}$

$\begin{array}{rr}0 & 0 \\ 3378 & 0 \\ 1895 & 0 \\ 0 & 0 \\ 8273 & 0\end{array}$

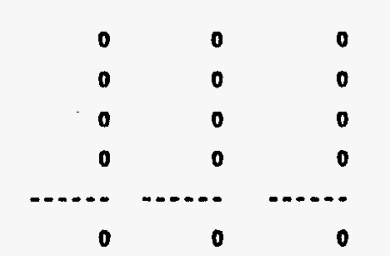

$\begin{array}{rr}0 & \\ 0 & 0 \\ 0 & 0 \\ 0 & 0 \\ 0 & 0 \\ 0 & 0\end{array}$

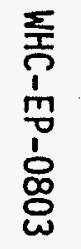

\begin{tabular}{rrrrrrrr}
1011 & 0 & 0 & 0 & 0 & 0 & 0 \\
1481 & 0 & 0 & 0 & 0 & 0 & 0 \\
0 & 515 & 0 & 0 & 0 & 0 & 0 \\
\hline 5491 & 515 & 0 & 0 & 0 & $\ldots \ldots$ & 0 & 0
\end{tabular} 
$6 / 27 / 94$

Maste class volumes $\left(m^{n} 3\right)$ by

Container Category and Maste Generator

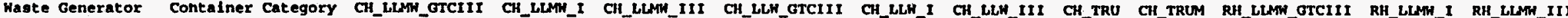

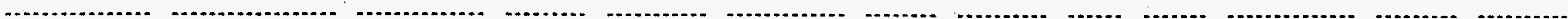

RKW CANOGA 55 GAL DRUM B-25 BOX Box $<120$

Total for RKH_CANOGA

STANFORD

4X4X8 BOX

55 GAL DRUM

Total for STANFORD

$\underset{1}{1}$

$\begin{array}{ll}\text { TPNL_2312 } & \text { 1X4X8 BOX } \\ & \text { BOX OTHER }\end{array}$

Total for TPNL_2312

TPNL_242B/BL

4X4X8 BOX

BOX OTHER

Total for TPML_242B/BL

TPNE_306H

4X4X8 BoX

55 GAL DRUM

BOX OTHER

Total for TPNL_306H

TPNL_314

$4 \times 4 \times 8$ BOX

BOX OTHER

Total for TPNL_314

TPNL_324 $\quad 4 \times 4 \times 8$ BOX

TPNL_324 4X4X8 BOX

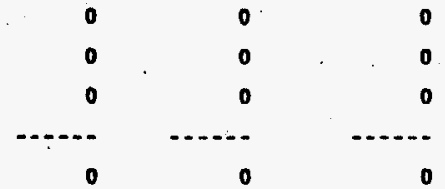

\begin{tabular}{rr}
0 & 0 \\
313 & 0 \\
1316 & 0 \\
\hdashline 1629 & 0
\end{tabular}
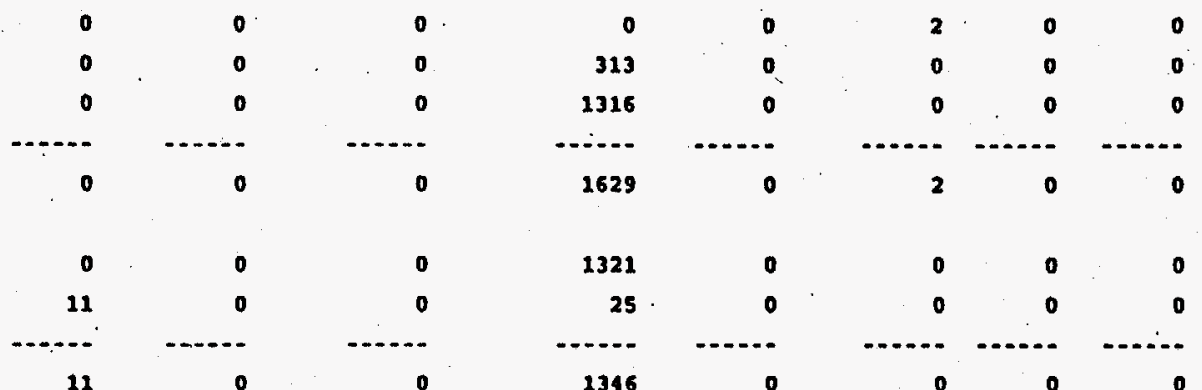

\begin{tabular}{rr}
1321 & 0 \\
25 & 0 \\
\hline 1346 & 0
\end{tabular}
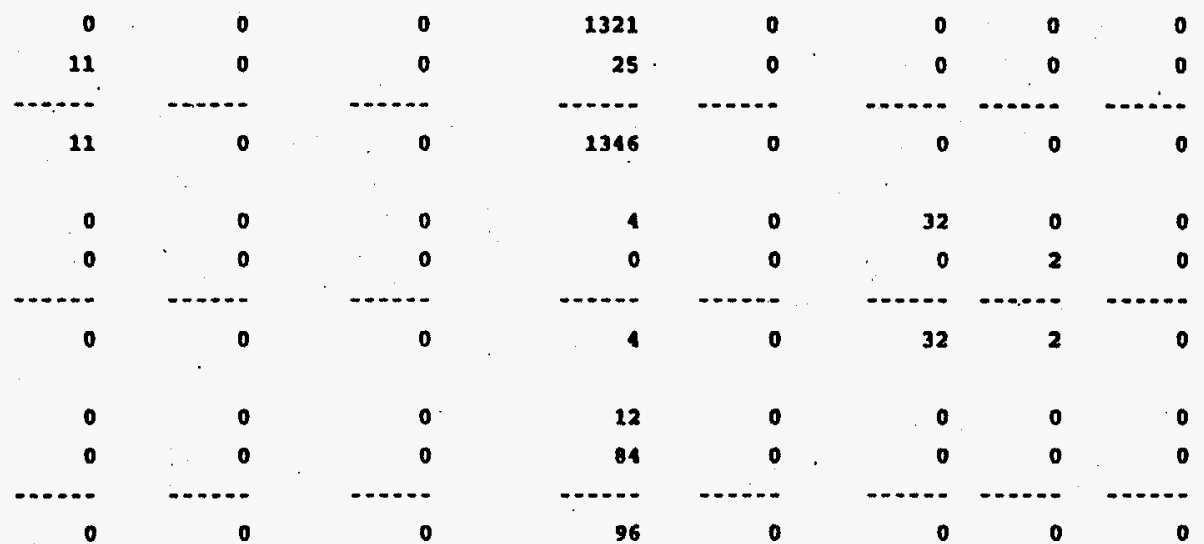

\begin{tabular}{rr}
12 & 0 \\
84 & 0 \\
\hdashline 96 & 0
\end{tabular}

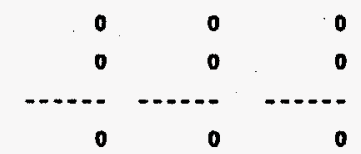
13
31

0
0
0
0

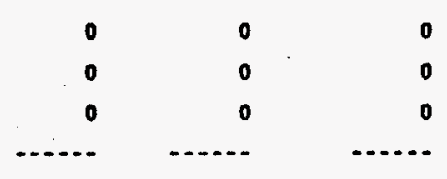

51

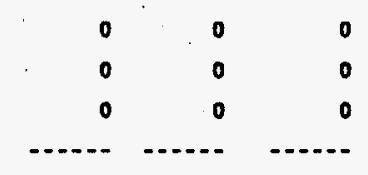

\begin{tabular}{rr}
1589 & 0 \\
1589 & 0 \\
\hdashline 3178 & 0
\end{tabular}
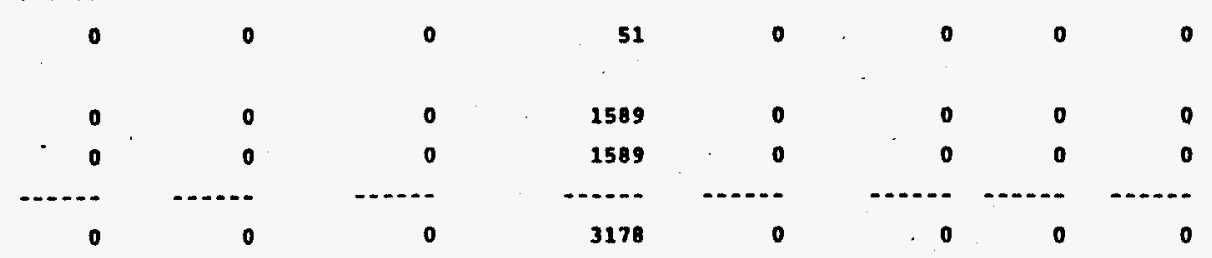
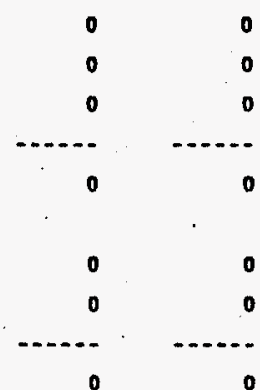

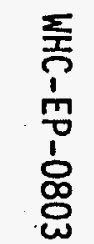

292

$\begin{array}{rr}0 & 0 \\ 0 & 0 \\ 0 & 0 \\ 0 & \\ 0 & 0 \\ 0 & 0 \\ 0 & 0\end{array}$

3

0$$
292
$$ 


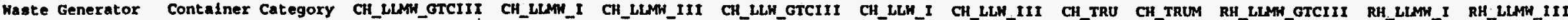

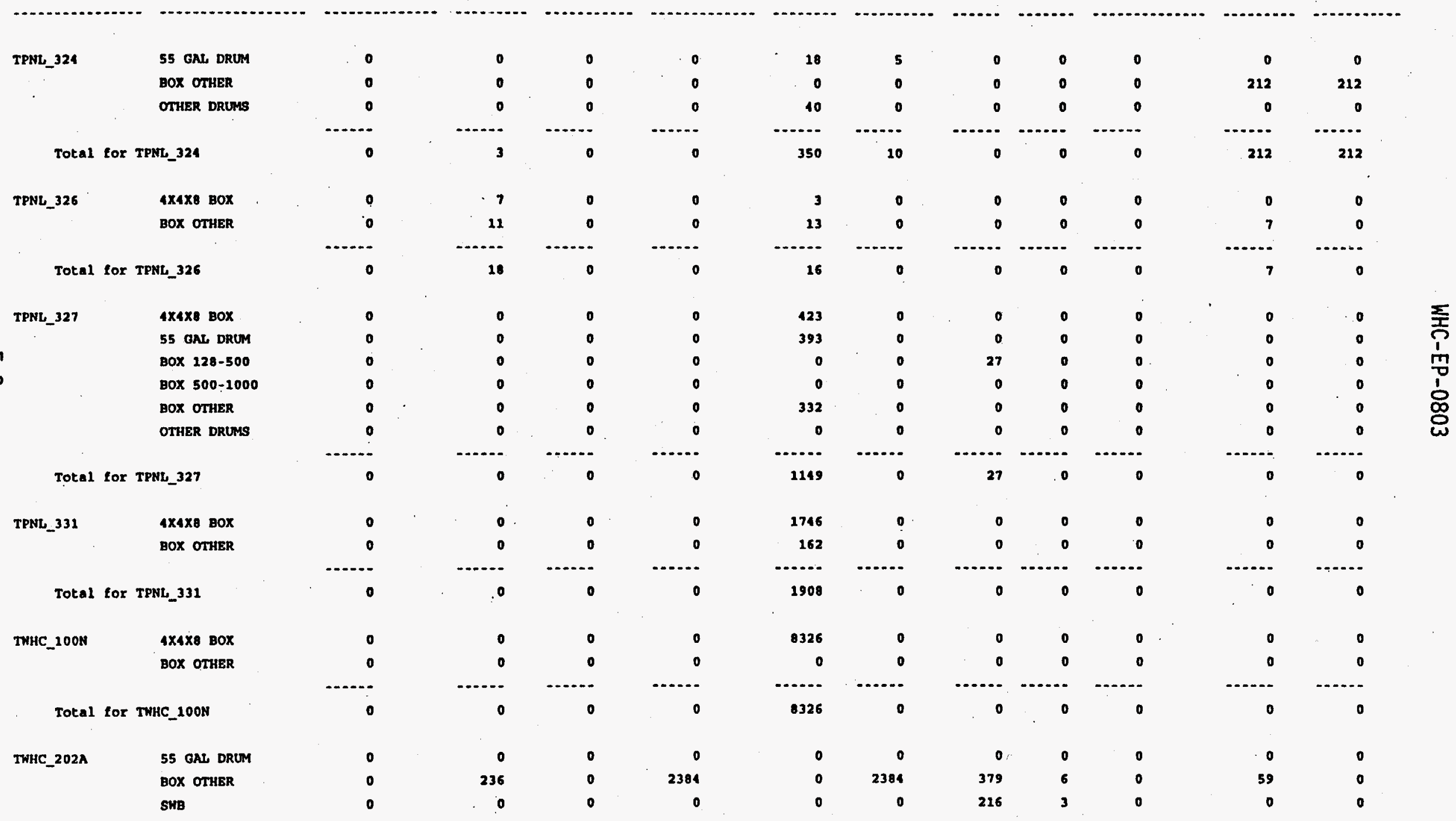


Waste Generator Container Category CH_Lrm_oTCIII

Total for TWHC_202A

THHC_202A_TW BOX OTHER

Total for THнC_202A_TH

TWHC_221T

$4 \times 4 \times 8$ BOX

55 GAS DRUM

BOX OTHER

Total tor TwHC_221T

$\underset{6}{1}$

906
0
906
-0

0
CH_LLMYII CH_LLM_III

_CH_LLH_GTCIII

(n-.......

CH_LLM_III CH_TRU CH_TRUM RH_LLMH_OTCIII RH_LLMH_I RH_LLMH_III

236
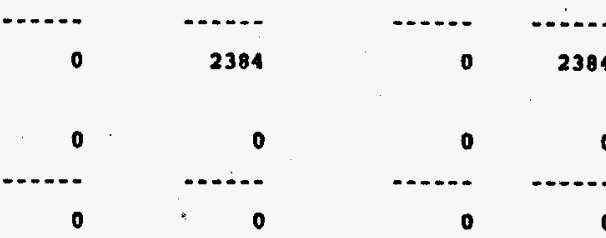
(......- -......-
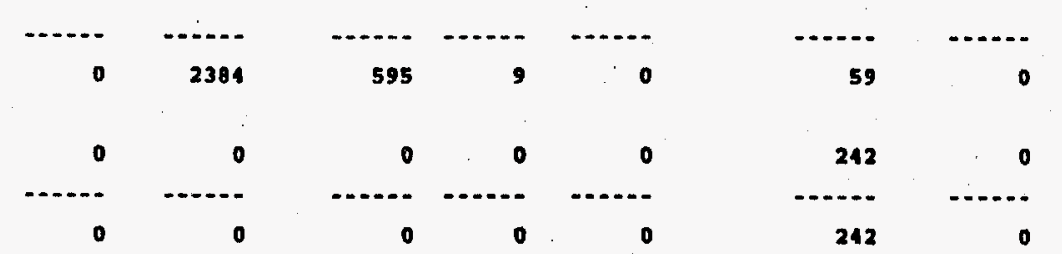

Total for TWHC_222S

Tинс_225B

\section{$4 \times 4 \times 8$ BOX}

BOX OTHER

Total for TWHC_225B

TWHC_23452

4X4X8 BOX

55 GAL DRUM

BOX OTHER

Total for THHC_23452

TWHC_242A

$4 \times 4 \times 8 B O X$

BOX OTHER

0
0
0

$\begin{array}{r}1813 \\ 0 \\ 1813 \\ \hdashline \ldots . . \\ \hline 3526\end{array}$

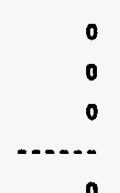

\begin{tabular}{rr}
3572 & 0 \\
0 & 0 \\
3572 & 0 \\
\hdashline & 0
\end{tabular}

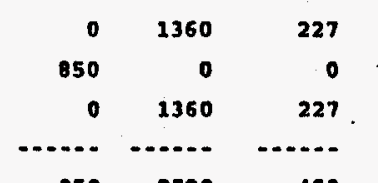

\begin{tabular}{rr}
0 & \\
36 & 0 \\
0 & 0 \\
\hdashline & 0
\end{tabular}

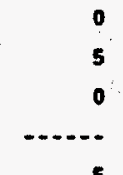

(5)

0
0
0
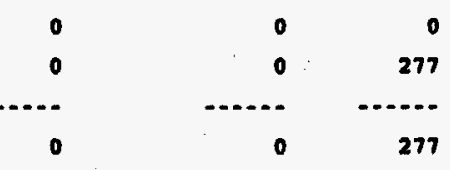

277
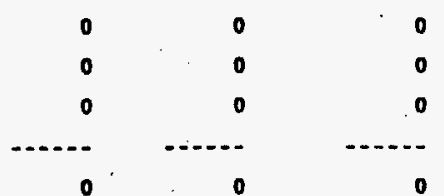

$20 \quad 12$
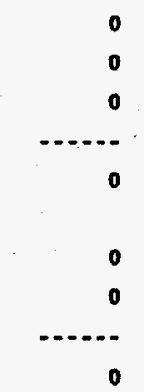

0
0
0
0

\begin{tabular}{rr}
9078 & 0 \\
3661 & 0 \\
64 & 0 \\
\hdashline$\ldots .$. & $\ldots$. \\
\hline 12803 & 0
\end{tabular}

\begin{tabular}{rr}
2270 & 0 \\
1610 & 27387 \\
\hline &.- .2 \\
\hline
\end{tabular}

6880

27387

$\begin{array}{rr}0 & 0 \\ 0 & 0 \\ 0 & 0 \\ 0 & 0\end{array}$
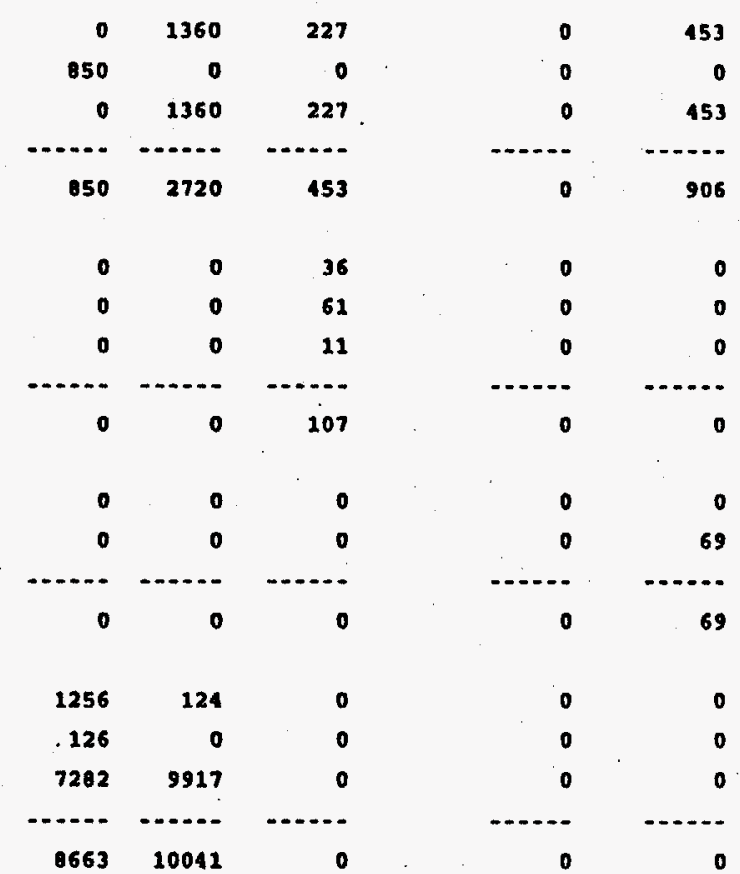

$\begin{array}{rr}0 & 0 \\ 0 & 0 \\ 0 & 0 \\ 0 & 0\end{array}$

$\begin{array}{rrr}0 & 20 & 12 \\ 0 & 103 & 110\end{array}$

20

0

$\begin{array}{rrr}0 & 0 & 2 \\ 0 & 0 & 20\end{array}$


Waste Generator

contalner category CH_LLM_GrCIII CH_LLM__I
CH_LLM_III CH_LLH_GTCIII CH_LLW_I

\begin{abstract}
-
\end{abstract}
Total for TWHC 242A

TWHC_242S 4X4X8 BOX BOX OTHER

Total for TWHC_242S

TWHC_242T

$4 \times 4 \times 8$ Box BOX OTHER

Total for TWHC_242T

雚 тинс_306

4x4x8 80x

Total for THHC_306

THHC_308

4X4X8 BOX

55 GAL DRUM

SNB

Total for TWHC_308

$\begin{array}{ll}\text { TWHC_340 } & \text { BOX 128-500 } \\ & \text { BOX OTHER }\end{array}$

Total for TWHC_ 340

THHC_GROUT

$4 \times 4 \times 6$ BOX

Total for TWHC_GROUT

TWHC_HWVP $\quad 4 \times 4 \times 8$ BOX

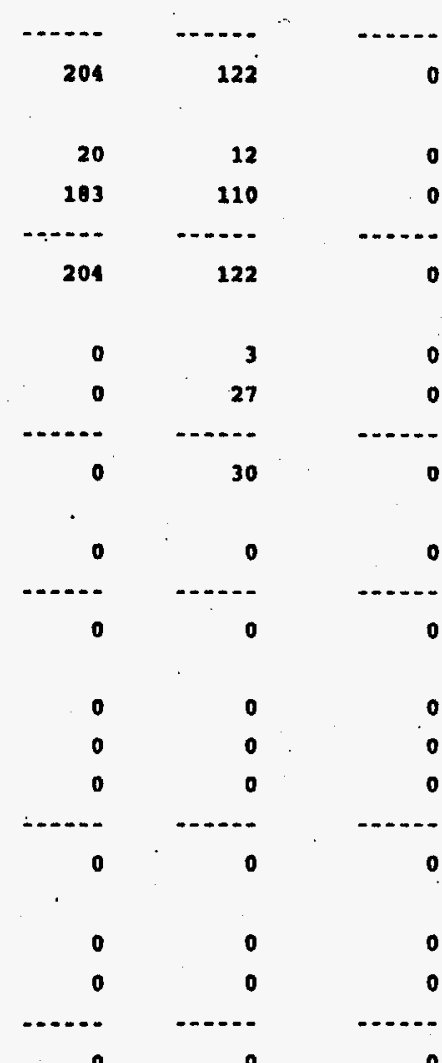

0
0
0
0

4
30
34

34
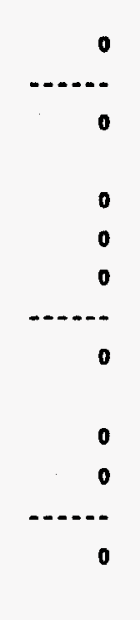

0
0

.

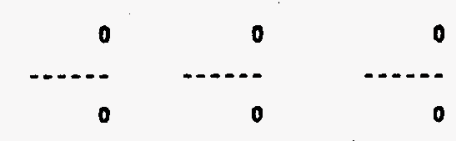

$147 \quad 221$

368
RH_LLMH_I RH_LLMH_III
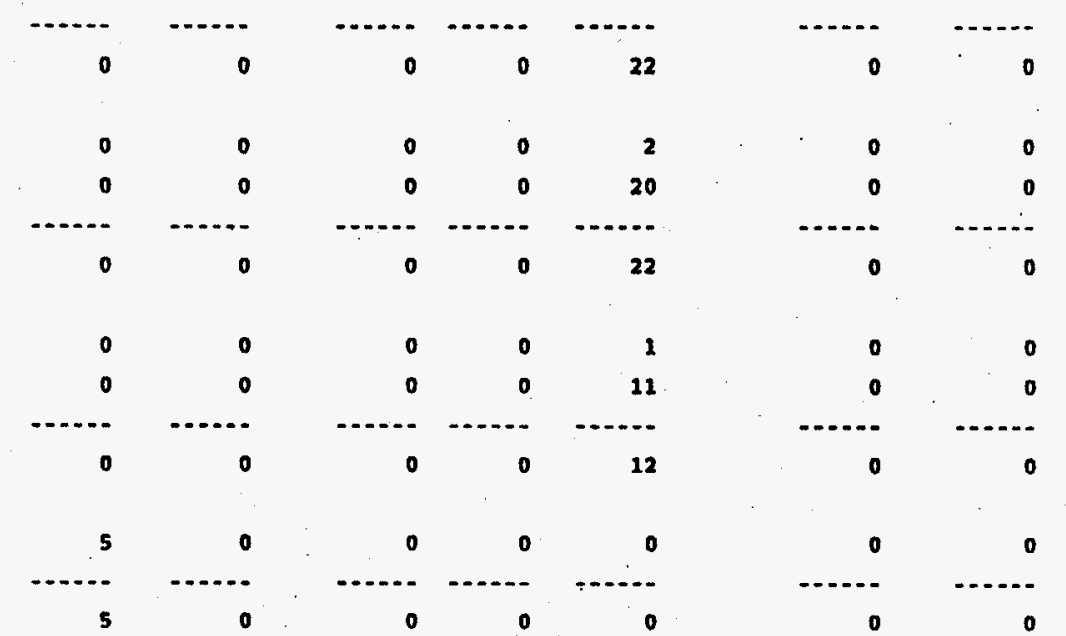

\begin{tabular}{rr}
116 & 0 \\
12 & 0 \\
0 & 0 \\
\hdashline 129 & 0
\end{tabular}

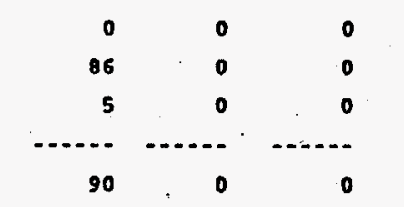

$\begin{array}{rr}0 & 0 \\ 0 & 0\end{array}$ $\begin{array}{rr}276 & 0 \\ -276 & 0 \\ & \\ 368 & 736\end{array}$

736 
$6 / 27 / 94$

Haste class Volumes $\left(m^{\wedge} 3\right)$ by

Contalner Category and Maste Generator
Contalner Category CH_LLm_atciII Chend

CH_LLMH_11

CH_LLW_OTCIIt CH_LLH_I CH_LLH_III CH_TRU CH_TRUM RH_LLMH_OTCIII

RH_LLMH_I RH_LLMN_III

THHC_HWVP 55 GAL DRUM BOX OTHER SwB

Total for TWHC_HWVP

THHC_PX_CO18H 4X4X8 BOX

Total for THHC_PX_CO18H

TWHC_TRUSAF

\section{X4X6 BOX}

BOX OTHER

$\stackrel{\prod}{\rightleftarrows}$

Total for THHC_TRUSAF

vou

55 GAL DRUM

Total tor U_U

WHC_100

30 GAL DRUM 4X4X8 BOX

55 GAS DRUM

BOX $<128$

Total for WHC_100

WHC_100K
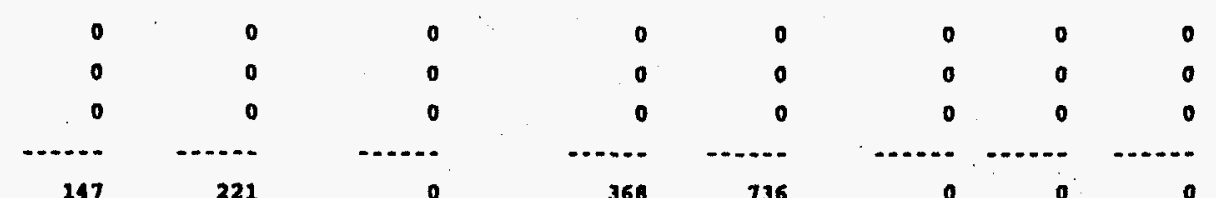

$\begin{array}{rrr}1501 & 98 & 0 \\ \ldots \ldots & 98 & \cdots \\ 1501 & 98 & 0\end{array}$
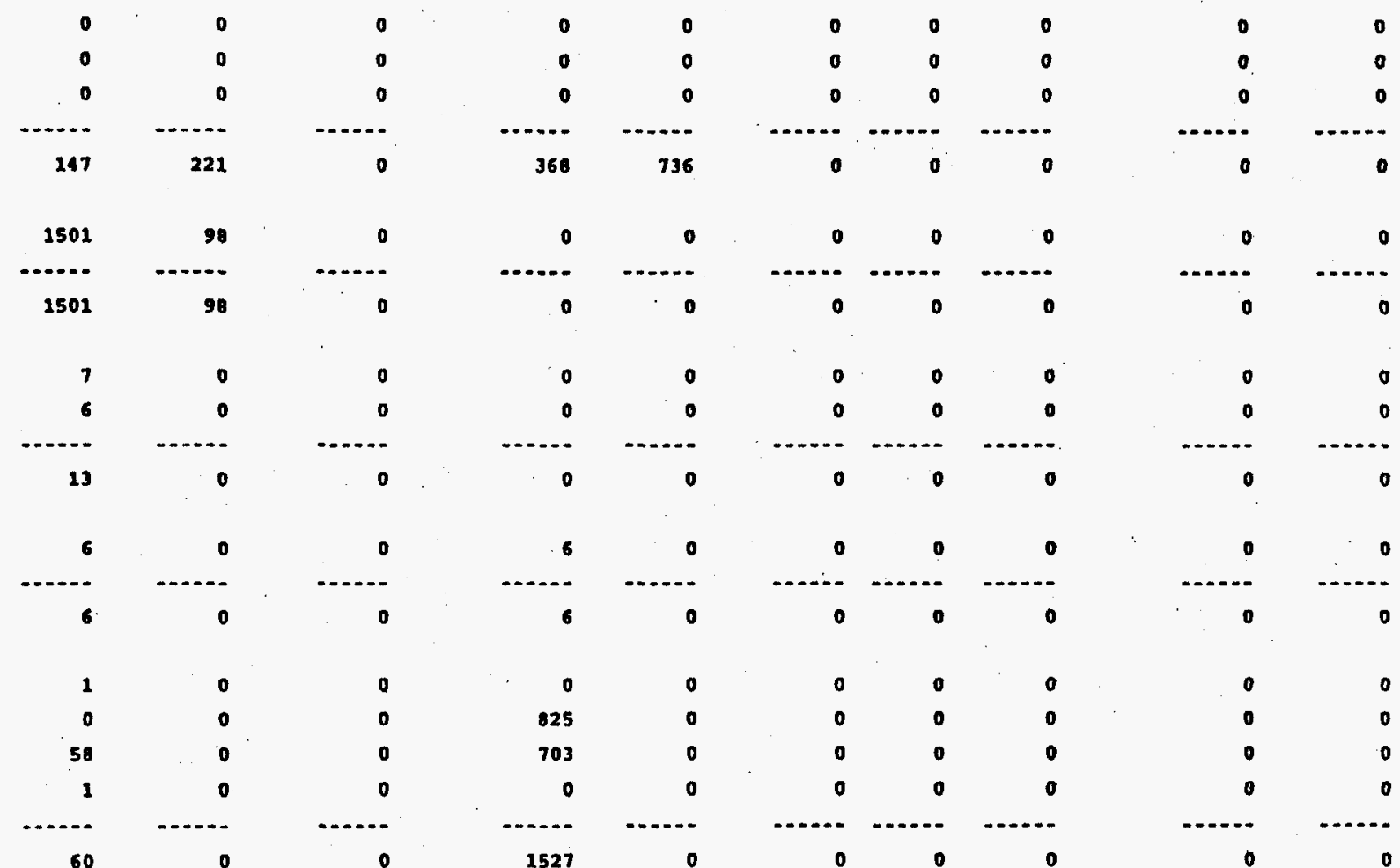

$\begin{array}{rr}0 & 0 \\ 1273 & 0 \\ 0 & 0 \\ 122 & 0 \\ 1078 & 0 \\ 0 & 0 \\ 0 & 0\end{array}$

$\begin{array}{rrr}0 & 0 & 0 \\ 133 & 0 & 0 \\ 0 & 0 & 0 \\ 0 & 0 & 0 \\ 0 & 0 & 0 \\ 0 & 0 & 0 \\ 0 & 0 & 0\end{array}$

\begin{abstract}
10 FT3 ION EX 277 FT3 ION EX 30 GAL DRUM $4 \times 4 \times 8$ BOX 55 GNL DRUM $B O X<128$ BOX OTHER
\end{abstract}


$6 / 27 / 94$

Waste class volumes $\left(m^{\wedge} 3\right)$ by

Container Category and Haste Generator

Waste Generator

Contalner Category

CH_LLMH_GTCIII

CH_LLWM_I

OTHER DRUMS

Total for MHC_100K

WHC_105DR

55 GAS DRUM

Total for HHC $105 \mathrm{DR}$

WHC_202A

\section{$4 \times 4 \times 8$ BOX}

55 GAL DRUM

SwB

0
0

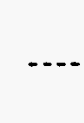

CH_LLMH_III

CH_LLH_GTCIII

$\stackrel{T}{N}$

Total for WHC_202A

WHC_221HE

30 GAL DRUM

Total for WHC_221HE

WHC_221T

4X4X8 Box

55 GAL DRUM

Total for HHC_221T

พHC_222S

\section{X4X8 BoX}

55 GAL DRUM

Total for WHC_222S

WHC_225B

4X4X8 BOX

55 GAL DRUM

BOX 128-500

BoX $<228$

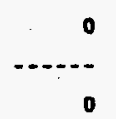

0
0
0

$\begin{array}{rr}0 & 0 \\ 14 & 1 \\ 0 & 0 \\ 14 & \end{array}$

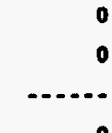

o

0
69
-2.

69

0
0
0

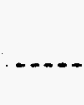

0
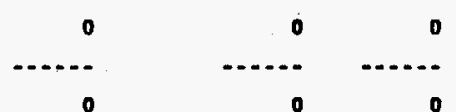

\begin{tabular}{rr}
1076 & 0 \\
71 & 0 \\
\hdashline 1147 & 0
\end{tabular}

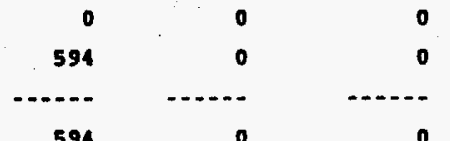

20

265

$\begin{array}{lll}0 & 0 & 0 \\ 1 & 0 & 0 \\ 0 & 0 & 0 \\ 0 & 0 & 0\end{array}$

18841

$\begin{array}{rr}84 & 0 \\ 10 & 6 \\ 0 & 38 \\ 46 & 0\end{array}$

\begin{tabular}{rrr}
205 & 0 & 0 \\
1445 & 68 & 0 \\
\hline 1651 & $6 .-2$ & $\cdots$
\end{tabular}

Cil_LLK_I

CH_LLH_III CH_TRU CH_TRUM
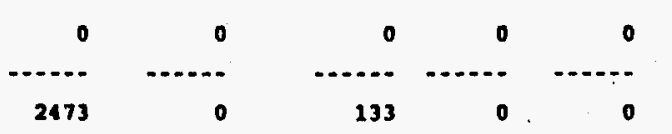

$\begin{array}{rr}0 & 0 \\ 0 & 0\end{array}$

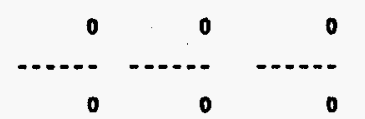

\begin{tabular}{rr}
194 & 0 \\
247 & 2 \\
0 & 0 \\
\hline 441 & 2
\end{tabular}
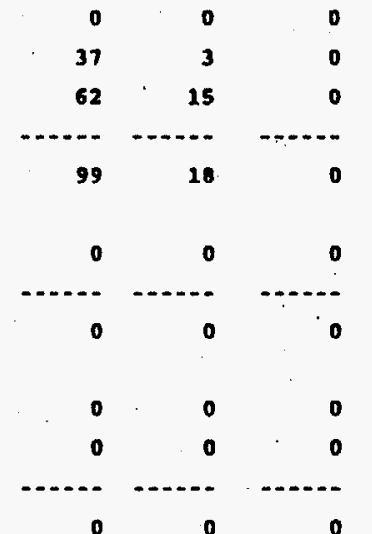

RH_LIMN_I RH_LLMA_III

151390

$\begin{array}{rrr}0 & 0 & 0 \\ 0 & 0 & 0 \\ 0 & 0 & 0\end{array}$
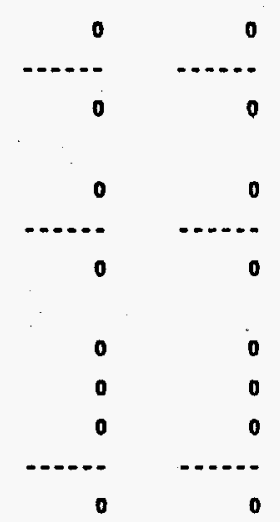

$\begin{array}{rr}0 & 0 \\ 0 & 0\end{array}$

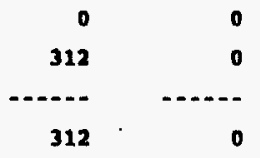

00

$\begin{array}{rr}122 & 0 \\ -. . & 0\end{array}$

1220

$\begin{array}{ll}0 & 0 \\ 0 & 0\end{array}$

$\begin{array}{ll}0 & 0 \\ 0 & 0\end{array}$


Waste Generator Cobntainer Category Ch_LLMH_OTCIII CH_LLMH_I CH_LLMH_III CH_LLH_OTCIII .................. - . .

Total for whC_225B

NHC_23452

4X4X8 BOX

55 OAL DRUM

SWB

Total for wHC_23452

WHC_2724W 4X4Xe BOX

Total for WHC_2724K

$\underset{1}{m}$

$$
\begin{array}{ll}
\text { WHC_2ETF } & \text { 4X4X6 BOX } \\
& 55 \text { OAL DRUM } \\
& \text { BOX } 128-500
\end{array}
$$

Total for WHC_2ETF

WHC_303K

4X4Xe BOX

55 GAL DRUM

Total for WHC_303K

WHC_ 308

4X4X8 BOX

55 GAL DRUM

HHC_340

\section{4xixe $80 \mathrm{x}$}

55 GNE DRUM
Total for MHC_308
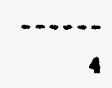

$\begin{array}{rrr}0 & 0 & 0 \\ 219 & 0 & 0 \\ 0 & 0 & 0 \\ 2 & \ldots & 0\end{array}$

. 219

$\begin{array}{rr}0 & 0 \\ 0 & 0\end{array}$

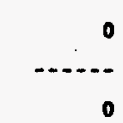

2154

$$
593
$$$$
595
$$

3342

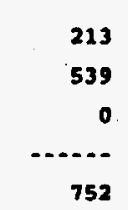

$\begin{array}{rr}0 & 0 \\ 17 & 0 \\ 11 & 0\end{array}$

17

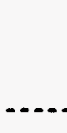

$\ldots$

0
0
0

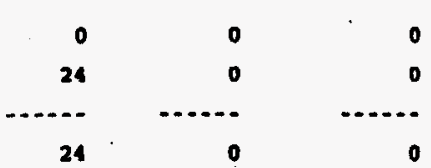

0
0
0

0

......

CH, Let I

CH_LLH_III CH_TRU CH_TRUM RH_LIMH_GTCIII RH_LLMH_I RH_LLMW_III
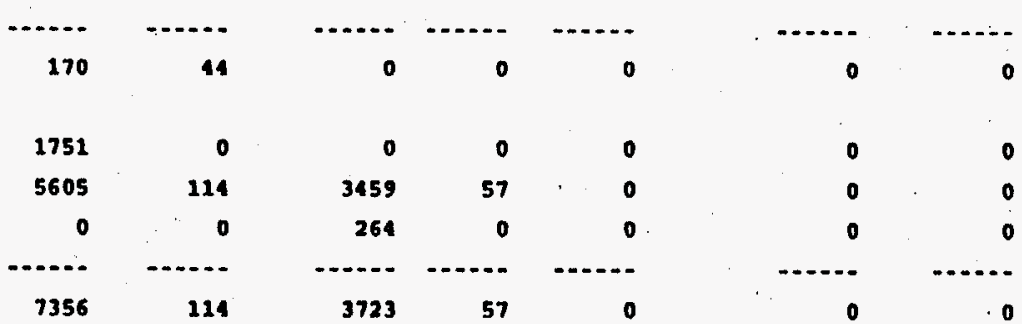

$\begin{array}{rr}1751 & 0 \\ 5605 & 114 \\ 0 & 0 \\ 7356 & 114\end{array}$

$\begin{array}{rr}3480 & 0 \\ 3900 & 0\end{array}$

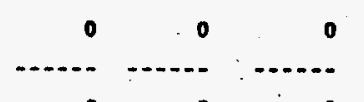

$14641 \quad 0$

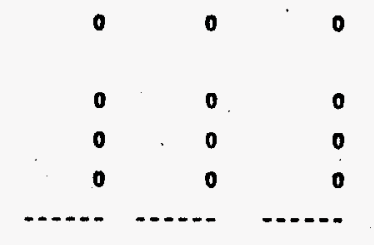

15240

-...-

-...-. - - -...o

$\begin{array}{rr}229 & 0 \\ 0 & 0\end{array}$

$\begin{array}{rrr}0 & 0 & 0 \\ 0 & 0 & 0 \\ 0 & 0 & 0\end{array}$

$\begin{array}{rr}0 & 0 \\ 0 & 0 \\ 0 & 0 \\ 0 & 0\end{array}$

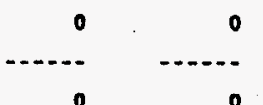

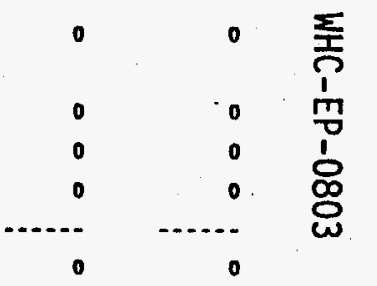

Total for wHC_ 340

\begin{tabular}{r}
0 \\
0 \\
\hdashline \\
0
\end{tabular}
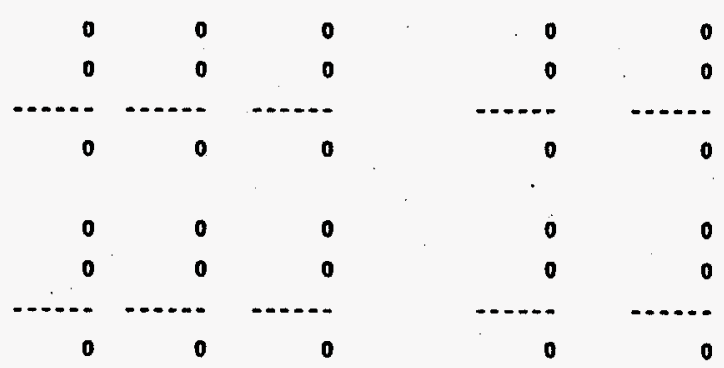

\begin{tabular}{rr}
171 & 0 \\
255 & 12 \\
\hdashline 926 & 12
\end{tabular}

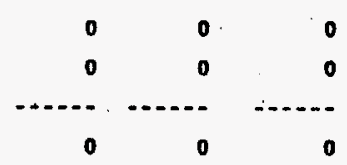




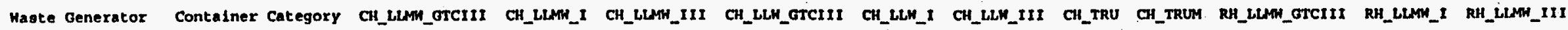
..................-

HHC_377 $3 \times 4 \times B$ BOX
55 GAL DRUM BOX OTHER

Total fox HHC_377

MHC_BKLOO

\section{$4 \times 4 \times 8$ BOX \\ 55 GAL DRUM BOX 128-500 BOX 500-1000 OTHER DRUMS}

$\underset{1}{\stackrel{1}{1}}$

Total for wHC_BQuip

WHC_DSTPSRET $\quad 55$ GNL DRUM

Total for WHC_DSTPSRET

HHC_DST_PRT CASKS

Total for MHC_DST_PRT

WHC_DST_RET $\quad 55$ GAL DRUM

Total for WHC_DST_RET

WHC_EA_W112 55 GAC DRUM

Total for WHC_EA_W112

\begin{tabular}{rrrr}
0 & 0 & 0 & 0 \\
0 & 0 & 0 & 0 \\
0 & 3 & 0 & 0 \\
\hline 0 & 3 & 0 & 0
\end{tabular}

$\begin{array}{rr}408 & 69 \\ 121 & 0 \\ 10 & 0 \\ 15 & 0 \\ 1 & 0 \\ \ldots . . & \ldots\end{array}$

854

7663

7663
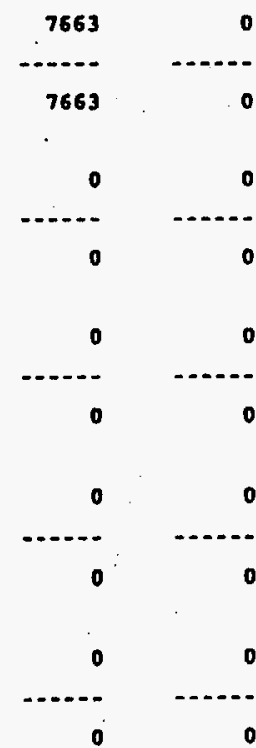
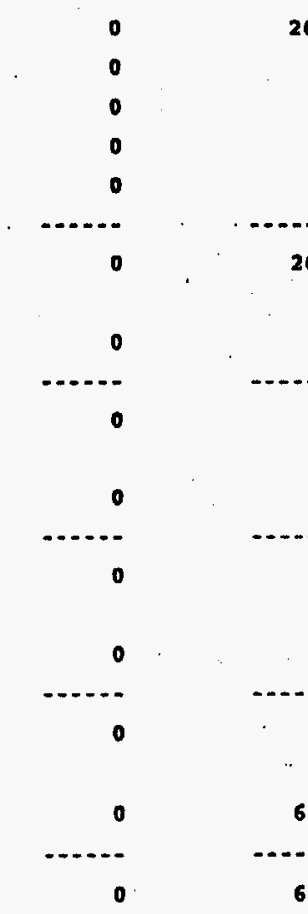

673

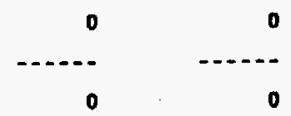

$\begin{array}{rr}7 & 0 \\ 19 & 0 \\ 0 & 0 \\ 26 & 0\end{array}$
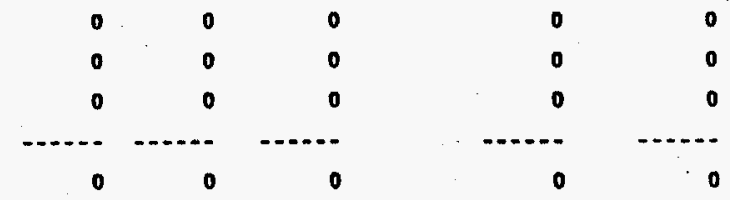

\begin{tabular}{rr}
265 & 1 \\
1 & 0 \\
0 & 0 \\
0 & 0 \\
0 & 0 \\
\hline 266 & 4
\end{tabular}

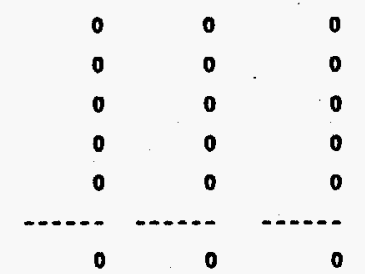

$\begin{array}{rr}0 & 0 \\ 0 & 0 \\ 0 & 0 \\ 0 & 0 \\ 0 & 0 \\ 0 & 0\end{array}$
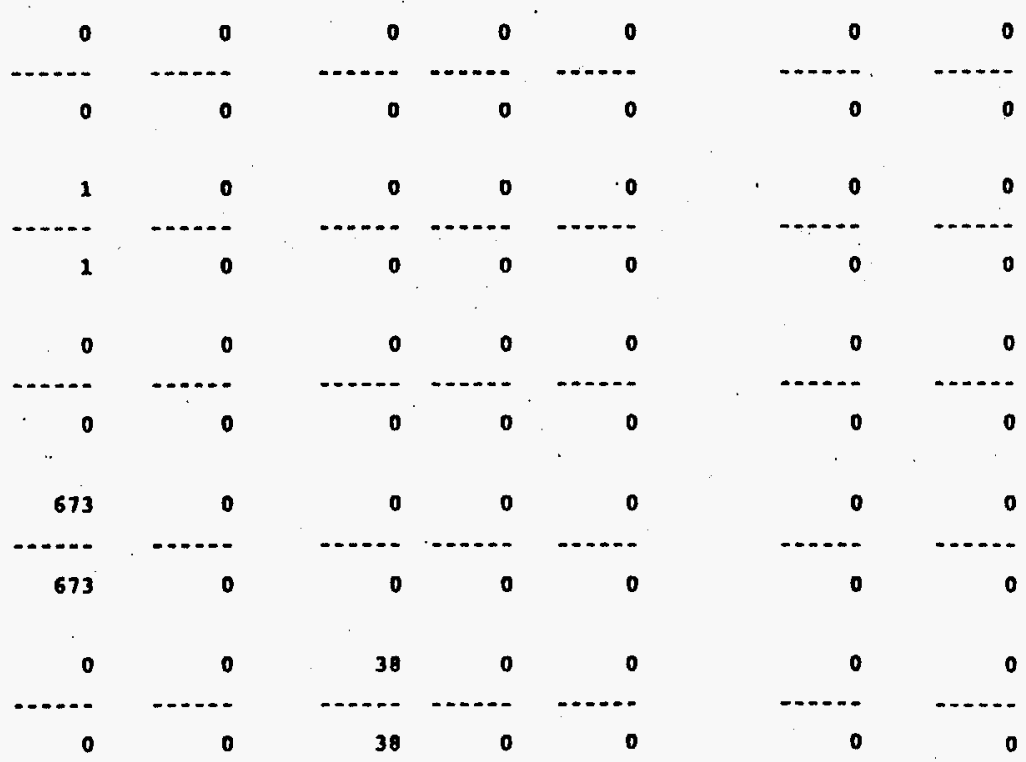
Haste Generator Container Category CH_Ltm_otcrir

HHC_EA_ML13 T5 GAL DRUM

Total for WHC_EA H113

WHC_EA_H221 55 GNI DRUM

Total for HHC_EA_M221

HHC_FFTF_MAINT $4 \times 4 \times 8$ BOX

55 GAL DRUM

CASKS

$\underset{1}{m}$

Total for WHC_EFTF_MAINT

WHC_GROUT

4X4X8 BOX

55 GAL, DRUM

BOX 128-500

BOX 500-1000

Box $<128$

BOX $>1000$

CASKS

Total for HHC_GROUT

WHC_HWVP

\section{$4 \times 4 \times 6$ BOX}

55 GAL DRUM

BOX OTHER

SWB

Total for WHC_HWVP

WHC_LO45H

55 GAL DRUM

0
0
0

CHILLMH_III CH_LLH_GTCXII

CH_LLH_I

CH_LLH_III

CH_tRU CH_tRUM

R_LLMW_GTCIII RH_LLMA_I RH_LLMF_III
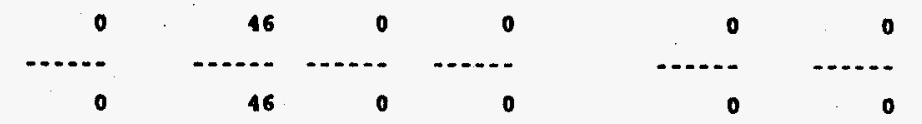

$\begin{array}{rrrr}0 & 0 & 0 & 0 \\ 0 & \cdots & \cdots & 0\end{array}$

$\begin{array}{rr}0 & 0 \\ 0 & 0\end{array}$
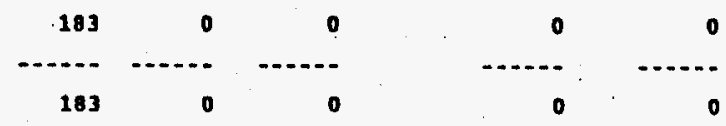

\begin{tabular}{rrr}
0 & 0 & 0 \\
0 & 0 & 0 \\
0 & 0 & 0 \\
\hline 0 & 0 & 0
\end{tabular}
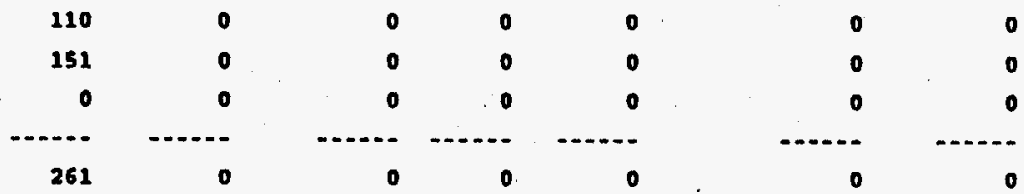

$3503 \quad 152$

$\begin{array}{rrr}0 & 0 & 0 \\ 129 & 062 & 0 \\ 0 & 93 & 0 \\ 0 & 179 & 0 \\ 0 & 14 & 0 \\ 0 & 0 & 0 \\ 0 & 0 & 0 \\ 129 & 1140 & \ldots\end{array}$
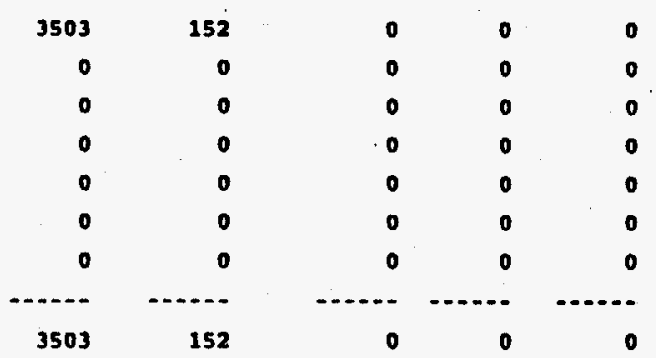
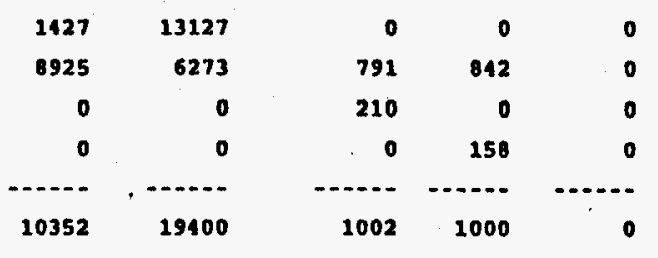

$\begin{array}{rr}0 & 0 \\ 0 & 0 \\ 0 & 0 \\ 0 & 0 \\ 0 & 0\end{array}$

6261 
$6 / 27 / 94$

Waste class Volumes $\left(m^{\wedge} 3\right)$ by

Container Category and Haste Generator

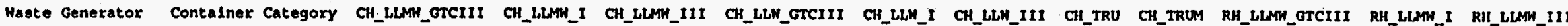

Total for WHC_ $2045 \mathrm{H}$

MHC_LLBO

55 GAL DRUM

B-25 BOX

Box $<128$

Total for WHC_LLBO

WHC_PX_CO18H

4X4XB BOX

55 GAL DRUM

BOX $<128$

$\prod_{0}^{1}$

Total for WHC_pX_CO18H

$\begin{array}{ll}\text { HHC_SSTRET } & \text { 4X4XB BOX } \\ & 55 \text { GAL DRUM }\end{array}$

Total for MHC_SSTRET

WIIC_SURPLS_FAC $4 \times 4 \times 8$ BOX

55 GAL DRUM

BOX $>1000$

BOX OTHER

OTHER' CYL

OTHER DRUMS

Total for HHC_SURPLS_FAC

0
0
0
0
0
0

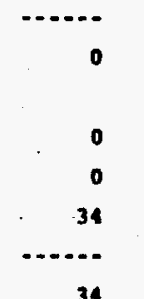

0
0
0
0
0
0

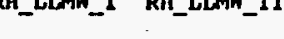

BOX OTHER
OTHER CYL
OTHER DRUMS

0
0
0
0

\begin{tabular}{rrr}
210 & 0 & 0 \\
603 & 4782 & 0 \\
167 & 0 & 0 \\
\hline 90 & $\ldots .-2$ & $\cdots$
\end{tabular}

$\begin{array}{ll}\text { ! HHC_TRUSAF } & 55 \text { GAL DRUM } \\ & \text { B.25 BOX }\end{array}$

Total for WHC_TRUSAF
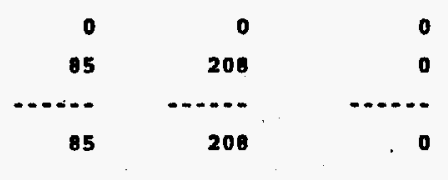

208

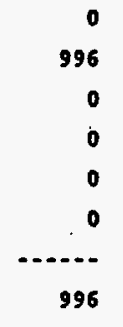

\begin{tabular}{rr}
0 & 0 \\
929 & 0 \\
0 & 0 \\
0 & 0 \\
0 & 0 \\
0 & 39943 \\
\hline 929 & 39943
\end{tabular}

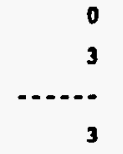

39943

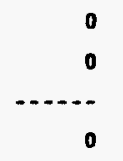

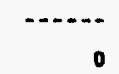
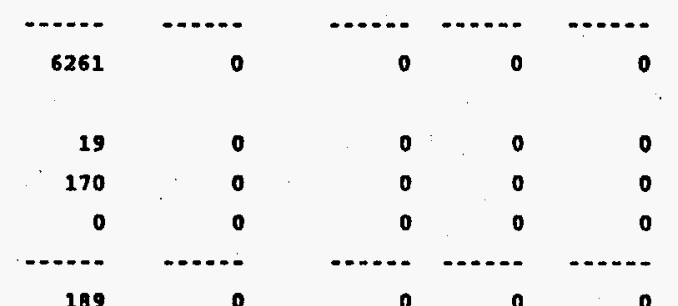

1890

$\begin{array}{rr}0 & 0 \\ 0 & 0 \\ 0 & 0 \\ 0 & 0\end{array}$

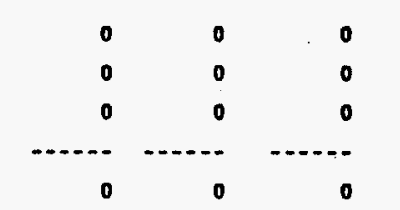

$\begin{array}{rr}591 & 0 \\ 0 & 0 \\ 591 & 0\end{array}$

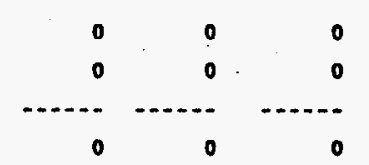

582653

582653
50630

$$
25035
$$

285532

.....

$943850 \quad 09655$
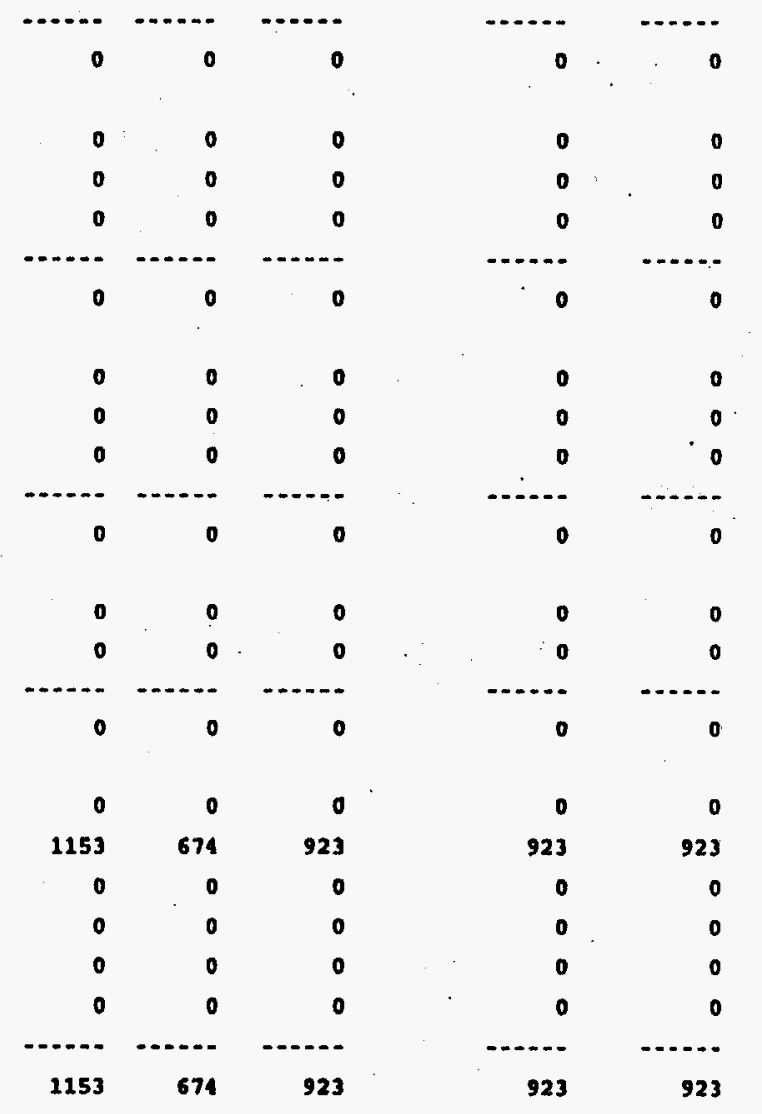
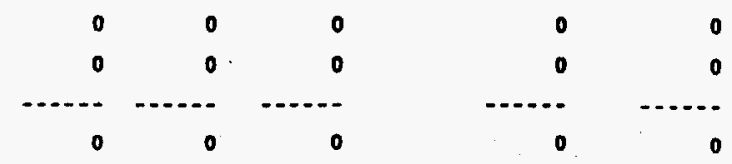
$6 / 27 / 94$

Haste class volumes $\left(m^{\wedge} 3\right)$ by

Contalner Category and Haste Generator

Maste Generator

Contalner Category CH_LLim_ OTCIII CH_LLMH_I

CH_LLMH_III

CH_LLH_GTCII

CH_LLII

CH_LLH_III CH_TRU CH_TRUM RH_LLMH_GTCIII RH_LWH_I RH_LLMH_LII

WHC_TWP_106C 4X4XB BOX

55 GAL DRUM
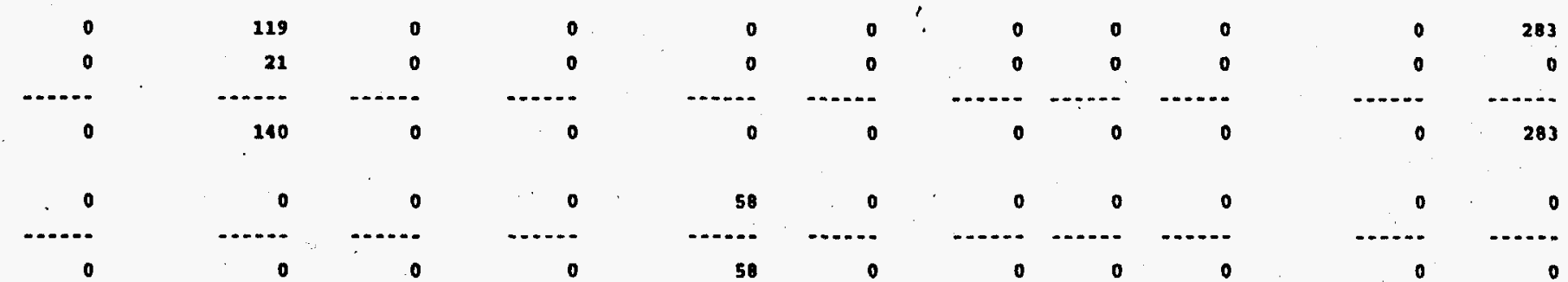

MHC_TWP_M028 $\quad 4 \times 4 \times 0$ BOX

Total for WHC_TWP_H028

WHC_TWP_พ030

$4 \times 4 \times 0 \cdot 80 x$

55 GND DRUM

0
0
0
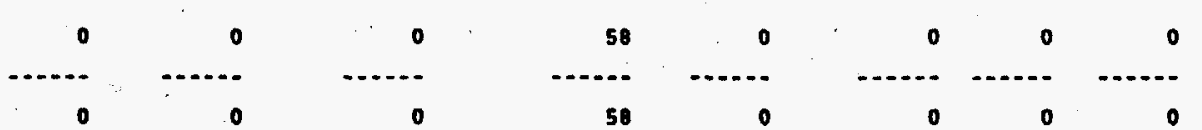

$\begin{array}{r}0 \\ 0 \\ \hdashline \quad .\end{array}$

$\underset{n}{1}$

WHC_TWP_W058 , 4X4X0 BOX

Total for WHC_THP_NOSO

HIC_TWP_W062
1X4X0 BOX
55 GAL DRUM

Total for HHC_THP_W062

WHC_TWP_H151 55 GAL DRUM

Total for WHC_TWP_H151

WHC_THP_W211 55 GAL DRUM

Total for WHC_TWP_H211
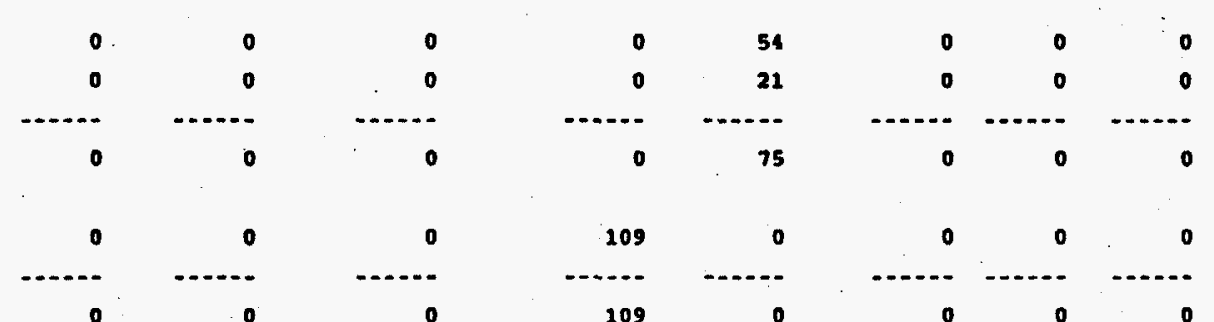

$\begin{array}{rr}109 & 0 \\ 109 & 0\end{array}$

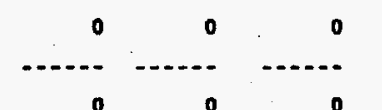

$\begin{array}{rr}0 & 0 \\ 0 & 0 \\ 0 & 0\end{array}$

0
0

0
0
0
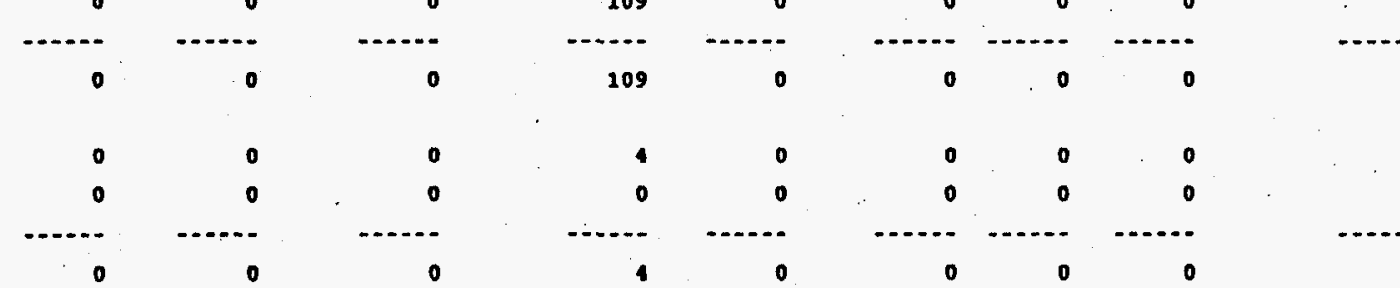

$4 \times 4 \times 8$ BOX

0
0
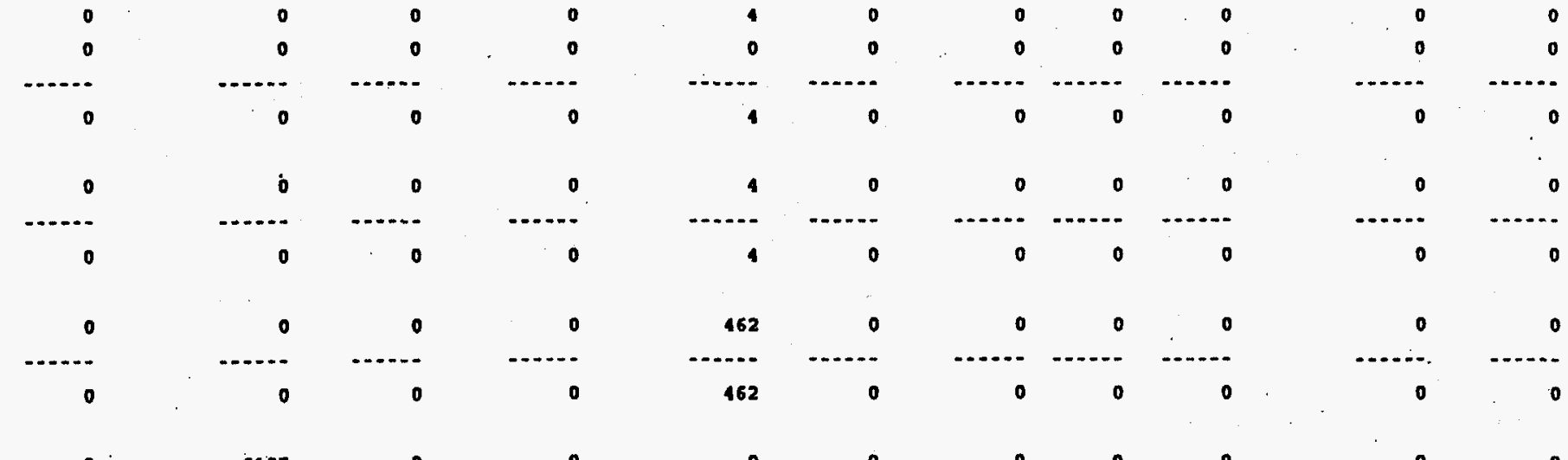

6197
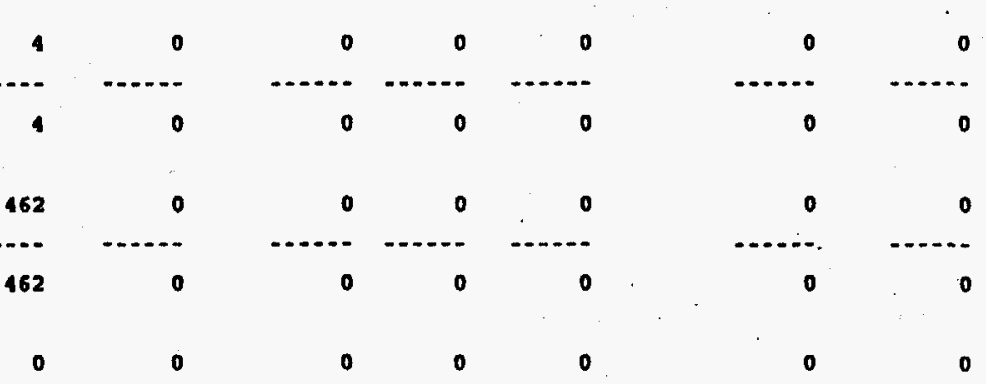


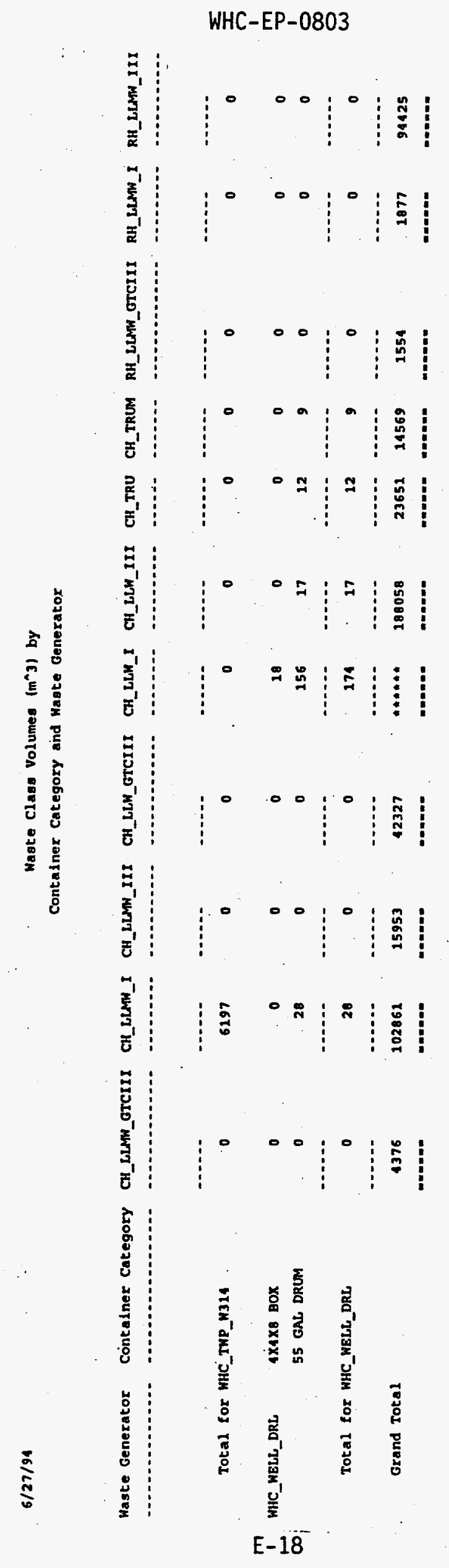


Waste clase volume $\left(m^{\wedge} 3\right)$ by

Contalnex Category and Waste Generator

Waste Generator Contalner Category RH_LLH_OTCIII RH_LLH_I RH_LLH_III RH_TRU RH_TRUM Total

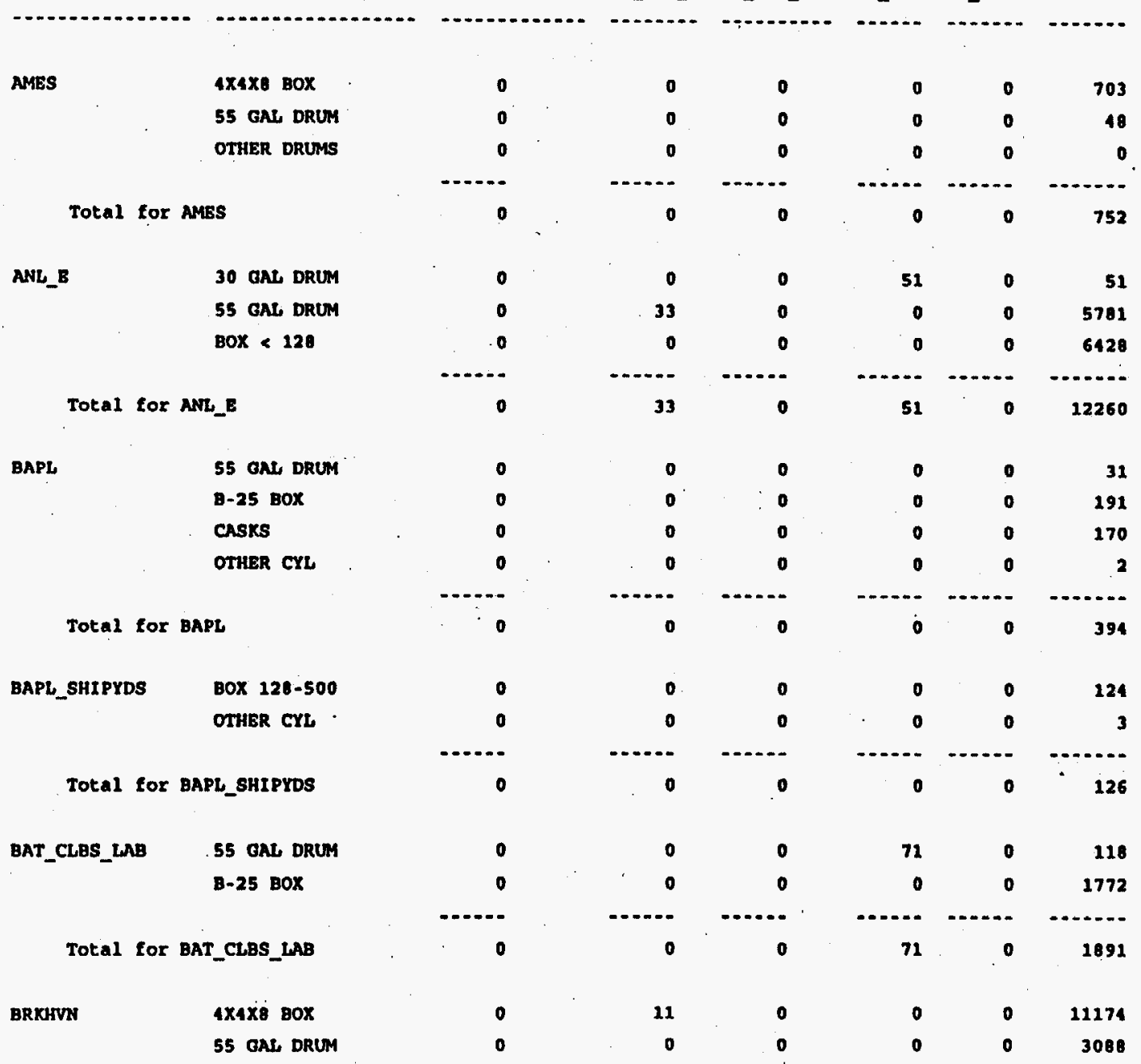


Maste Clase Volume $\left(m^{\wedge} 3\right)$ by Contalner Category and waste Generator

în

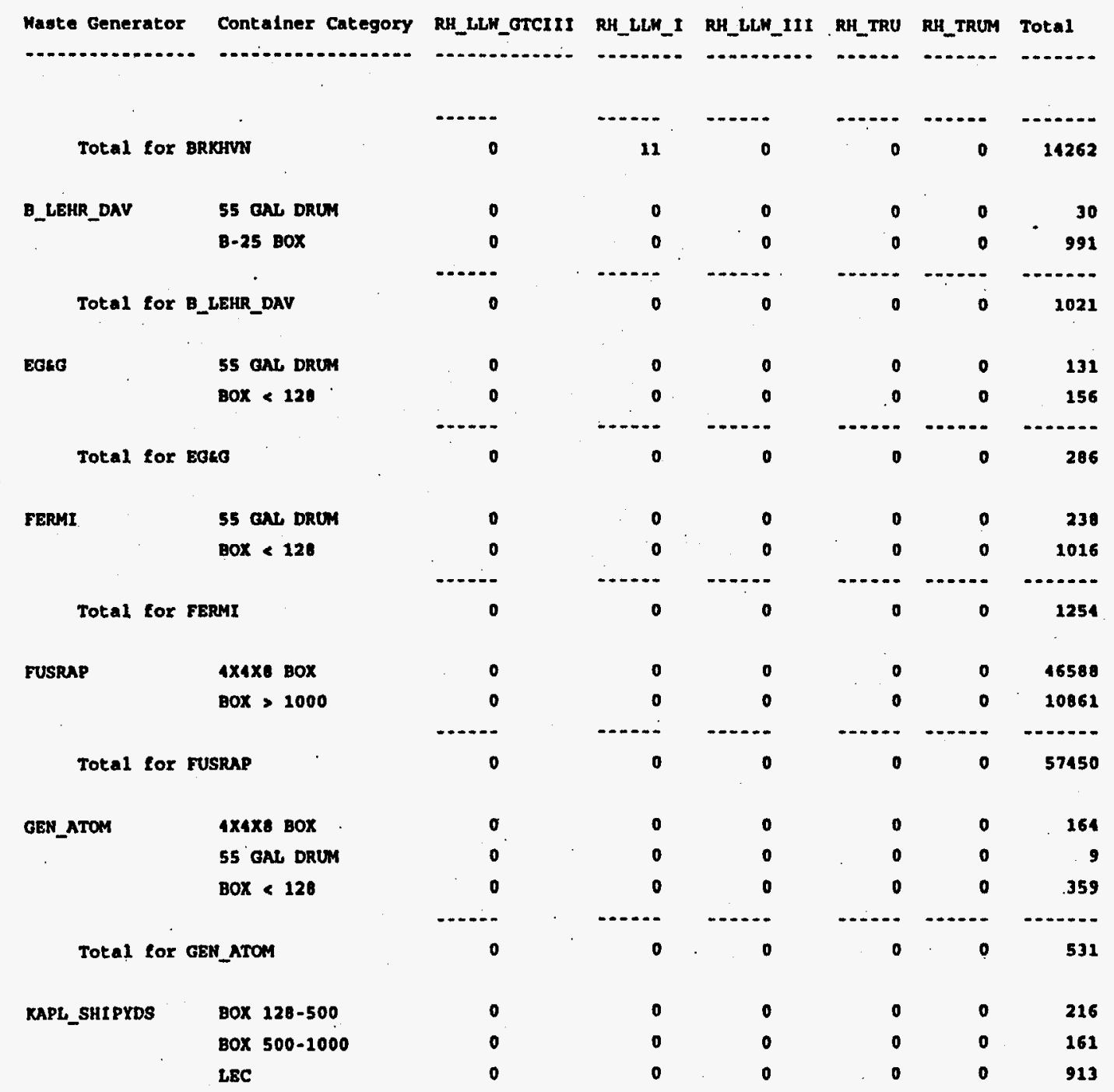


Maste class volume $\left(m^{\wedge} 3\right\}$ by

Container Category and waste Generator

\begin{tabular}{|c|c|c|c|c|c|c|c|}
\hline Waste Generator & Container Category & RH_LLH_OTCIII & RH_LLH_I & RH_LLH_III & RII_TRU & RH_TRUM & Total \\
\hline - & - & - & - n. & n & $\cdots \cdots$ & $-\infty \cdots$ & $\cdots+\infty$ \\
\hline & & $\therefore . .$. & ...... & $\cdots$ & $\cdots$ & $\cdots$ & - n.... \\
\hline Total for $x$ & PL_SHIPYDS & 0 & 0 & 0 & 0 & 0 & 1290 \\
\hline KEH_100 & 55 CAL DRUM & 0 & 0 & 0 & 0 & 0 & 61 \\
\hline & & $\cdots$ & $\cdots . .$. & $\ldots$ & $\cdots+.$. & $\ldots$ & $\cdots, \ldots$ \\
\hline Total for $x$ & H_100 & 0 & 0 & - & 0 & 0 & 61 \\
\hline LBL & 55 cAl DRUM & 0 & o & 0 & o & 0 & .930 \\
\hline & $80 x<128$ & 0 & 0 & 0 & 0 & 0 & 10039 \\
\hline & & 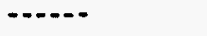 & ........ & $\ldots$ & …... & $\ldots . .$. & .......- \\
\hline Total for $\mathrm{t}$ & & 0 & o & - & 0 & 0 & 10969 \\
\hline LENL & 55 CNL DRUM & 0 & 0 & 0 & 0 & 0 & 3276 \\
\hline & BOX e 128 & o & o & 0 & 0 & 0 & 2614 \\
\hline & $80 x>1000$ & 0 & 0 & o & 0 & 0 & 2324 \\
\hline & SWB & o & 0 & 0 & 0 & 0 & 122 \\
\hline & & $\cdots$ & ........ & $\cdots \cdot$ & $\cdots$ & $\cdots \cdot-\cdot$ & $\cdots \cdot-\cdot$ \\
\hline Total for 1 & N! & 0 & 0 & 0 & $\ldots$ & 0 & 8336 \\
\hline LL_EQUTP & LEC & o & 0 & 0 & o & 9748 & 97401 \\
\hline & & 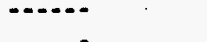 & $\cdots$ & $\cdots$ & $\cdots$ & (n........ & - \\
\hline Total for 1 & LQUUIP & 0 & 0 & o & 0 & 9740 & 97481 \\
\hline LL_EQUIP_SEC & $4 \times 4 \times 0$ B0x & o & o & 0 & 0 & 0 & 3293 \\
\hline & 55 GAL DRUM & 0 & $\mathbf{0}$ & 0 & 0 & 0 & 1634 \\
\hline Total for 1 & EQUIP_SEC & i & 0 & 0 & 0 & 0 & 1927 \\
\hline MIT_BATES & 55 GAL DRUM & o & o & 0 & 0 & 0 & 4 \\
\hline & & $\cdots$ & (n) & $\cdots$ & $\cdots$ & $\cdots$ & $\cdots$ \\
\hline Total tor & T_BATES & 0 & 0 & 0 & 0 & o & 4 \\
\hline PADUCAH_ES & 55 GAL DRUM & 0 & 0 & 0 & 0 & 0 & 17474 \\
\hline
\end{tabular}


Maste class volume $\left(m^{\wedge} 3\right)$ by

Container Category and Waste Generator

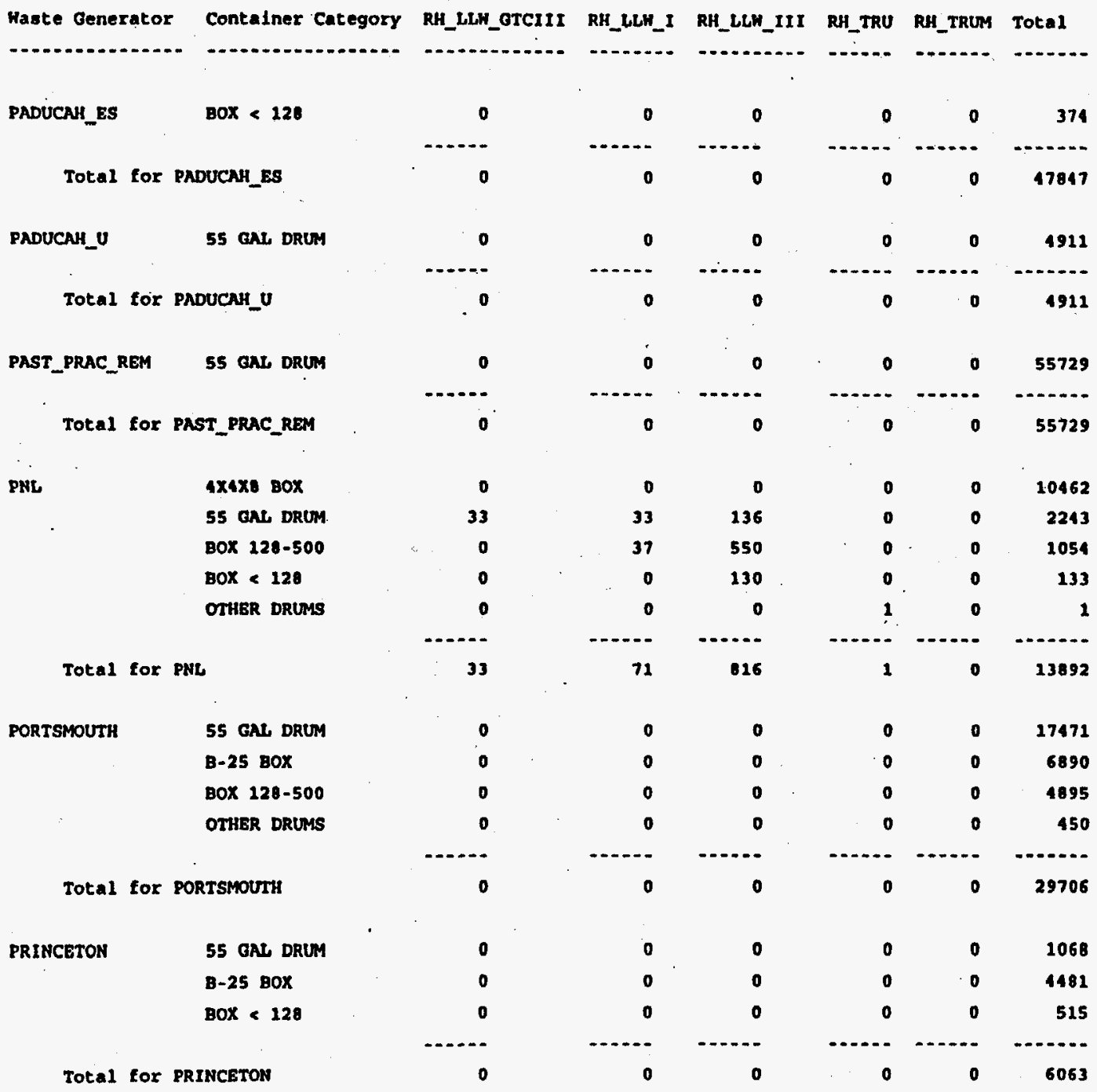


Waste class volume $\left(m^{*} 3\right)$ by

Contalner Category and Haste Genexator

\begin{tabular}{|c|c|c|c|c|c|c|c|}
\hline Haste Genexator & Contalner Category & RH_LLH_GTCIIT & RH_LEH_I & RH_LLH_III & RH_TRU & RH_TRUM & Total \\
\hline - & (n) & 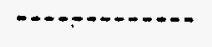 & .......... & . & $\cdots$ & $\cdots$ & $\ldots$ \\
\hline \multirow[t]{4}{*}{ RKH_CANOCA } & 55 GAL DRUM & 0 & 0 & 0 & 0 & 0 & 3 \\
\hline & B-25 BOX & 0 & 0 & o & 0 & 0 & 313 \\
\hline & $B 0 x<128$ & 0 & 0 & 0 & 0 & 0 & 1316 \\
\hline & & $\ldots$ & -- & (n.... & -. & $\cdots$ & $\cdots \cdots$ \\
\hline Total for & M_cANOCA & 0 & 0 & 0 & 0 & 0 & 1631 \\
\hline \multirow[t]{3}{*}{ STANFORD } & $4 \times 4 \times 8$ BOX & 0 & 0 & 0 & 0 & 0 & 2321 \\
\hline & 55 GAI DRUM & 0 & 0 & 0 & 0 & 0 & 36 \\
\hline & & $\cdots+\cdots$ & $\cdots$ & -- & $\cdots$ & $\cdots$ & $\ldots . .$. \\
\hline Total for $S$ & ANFORD & 0 & 0 & 0 & 0 & 0 & 1358 \\
\hline \multirow[t]{3}{*}{ TPNL_2312 } & $4 \times 4 \times 8 B O X$ & 0 & 0 & 0 & 0 & 0 & 36 \\
\hline & BOX OTHER & 0 & 0 & 0 & 0 & 0 & 2 \\
\hline & & $\cdots \cdot-$ & $\cdots$ & $\cdots \cdot$ & $\cdots-\cdot$ & $\cdots$ & $\cdots \cdots$ \\
\hline \multicolumn{2}{|c|}{ Total for TPNL_2312 } & 0 & 0 & 0 & 0 & 0 & 30 \\
\hline \multirow[t]{3}{*}{ TPRL_2428/8L } & 4x4x8 Box & 0 & 0 & - & 0 & 0 & 12 \\
\hline & BOX OTHER & o & 0 & - & 0 & 0 & 84 \\
\hline & & (n) & $\cdots$ & $\cdots-1$ & $\cdots$ & $\cdots$ & $\cdots \cdots$ \\
\hline \multicolumn{2}{|c|}{ Total for TPNI,_2428/BC } & 0 & 0 & 0 & 0 & 0 & 96 \\
\hline \multirow[t]{4}{*}{ TPNL_306W } & $4 \times 4 \times 8$ 80x & 0 & 0 & 0 & 0 & 0 & 13 \\
\hline & 55 GAL DRUM & 0 & o & 0 & 0 & 0 & 7 \\
\hline & BOX OTHER & o & - & 0 & 0 & o & 31 \\
\hline & & $\cdots$ & $\cdots$ & n...... & $\cdots$ & $\ldots$ & ........ \\
\hline \multicolumn{2}{|c|}{ Total for TPNL_306W } & 0 & 0 & 0 & 0 & $\mathbf{0}$ & 51 \\
\hline \multirow[t]{3}{*}{ TPNL_314 } & $4 \times 4 \times 8$ BOX & 0 & 0 & o & 0 & 0 & 1589 \\
\hline & BOX OTHER & 0 & 0 & 0 & o & 0 & 2589 \\
\hline & . & $\cdots$ & $\cdots$ & $\cdots$ & $\cdots \ldots$ & $\cdots$ & (........ \\
\hline \multicolumn{2}{|c|}{ Total for TPML_314 } & 0 & 0 & 0 & 0 & 0 & 3178 \\
\hline TPNE_324 & $4 \times 4 \times 0$ BOX & 0 & 0 & 14 & 0 & 0 & 314 \\
\hline
\end{tabular}


Waste class volume (m^3) by

Container category and Haste Generator

\begin{tabular}{|c|c|c|c|c|c|c|c|}
\hline Waste Generator & Container Category & RH_LLH_GTCIII & RH_LLW_I & RH_LLH_III & RH_TRU & RH_TRUM & Total \\
\hline - & 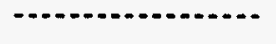 & - & -......... & - & $\cdots$ & -....... & -...... \\
\hline \multirow[t]{4}{*}{ TPNL_324 } & 55 GAL, DRUM & 0 & 12 & 0 & 0 & 0 & 35 \\
\hline & BOX OTHER & 4 & 0 & 0 & 0 & 0 & 128 \\
\hline & OTHER DRUMS & 0 & o & 0 & 0 & 0 & 10 \\
\hline & & $\cdots$ & $\cdots+$ & -..... & $\cdots$ & $\because$ & $\cdots$ \\
\hline \multicolumn{2}{|c|}{ Total for TPNL_324 } & 4 & 12 & 14 & 0 & i & 817 \\
\hline \multirow[t]{3}{*}{ TPNL_326 } & $4 \times 4 \times 880 x$ & 0 & 0 & 0 & 0 & o & g \\
\hline & BOX OTHER & 0 & 0 & 0 & 0 & 0 & 31 \\
\hline & & $\cdots$ & ….... & $\ldots . .$. & $\cdots$ & $\cdots$ & - \\
\hline \multicolumn{2}{|c|}{ Total for TPNL_326 } & 0 & 0 & 0 & 0 & 0 & 41 \\
\hline \multirow[t]{7}{*}{ TPNL_327 } & $4 \times 4 \times 8$ 80x & 0 & 0 & 0 & 11 & o & 434 \\
\hline & 55 GNL DRUM & 0 & 50 & 0 & 0 & 2 & 446 \\
\hline & BOX 128-500 & o & 214 & 0 & 0 & 0 & 240 \\
\hline & Box $500-1000$ & 0 & 0 & 0 & 726 & 0 & 726 \\
\hline & BOX OTHER & 0 & 6 & 0 & 171 & 0 & 510 \\
\hline & OTHER DRUMS & 0 & 44 & 0 & 107 & 6 & 157 \\
\hline & & $-\ldots$ & $\cdots$ & $\ldots$ & $\ldots$ & -..... & -....... \\
\hline \multicolumn{2}{|c|}{ Total for TPNL_327 } & 0 & 315 & 0 & 1015 & - & 2512 \\
\hline \multirow[t]{3}{*}{ TPNL_331 } & AX4Xa BoX & 0 & 0 & $\mathbf{0}$ & 0 & 0 & 1746 \\
\hline & BOX OTHER & 0 & 0 & 0 & 0 & 0 & 262 \\
\hline & & $\cdots$ & $\cdots \cdots$ & $\cdots$ & $\cdots+$ & - & (n......... \\
\hline \multicolumn{2}{|c|}{ Total for TPNL_331 } & 0 & 0 & 0 & 0 & 0 & 1908 \\
\hline \multirow[t]{3}{*}{ THHC_10ON } & $4 \times 4 \times 880 x$ & 0 & 0 & 0 & 0 & 0 & 8326 \\
\hline & BOX OTHER & 0 & .0 & 0 & 1186 & 0 & 1186 \\
\hline & & $-\cdots$ & $\cdots$ & $\cdots$ & $\cdots$ & -- & -...... \\
\hline \multicolumn{2}{|c|}{ Total for TWHC__100N } & 0 & 0 & 0 & 1186 & o & 9512 \\
\hline \multirow[t]{3}{*}{ TWHC_202A } & 55 GAT, DRUMY & 0 & 0 & 0 & 0. & 0 & 0 \\
\hline & BOX OTHER & 1055 & 0 & 137 & 119 & 32 & 6791 \\
\hline & SWB & 0 & 0 & 0 & $\dot{0}$ & 0 & 219 \\
\hline
\end{tabular}


Maste Class Volume $\left(\mathrm{m}^{\wedge} \mathrm{3}\right)$ by

ContaIner Category and Haste Generator

\begin{tabular}{|c|c|c|c|c|c|c|c|}
\hline Waste Generator & Contalner Categoxy & RH_LLH_GTCIII & RH_LLN_I & RH_LLH_III & RH_TRU & RH_TRUM & Total \\
\hline \multirow{2}{*}{ 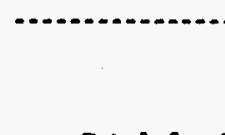 } & 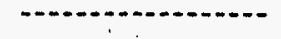 & n. & n......... & -.............. & ...... & -...... & $\cdots$ \\
\hline & & $\cdots \cdots$ & $\cdots$ & $\cdots$ & $\cdots$ & $\cdots+$ & -...... \\
\hline \multirow[t]{2}{*}{ Total for } & $M C_{-} 202 A$ & 2055 & 0 & 137 & 119 & 32 & 7010 \\
\hline & - & & & & & & \\
\hline \multirow[t]{2}{*}{ TWHC_202A_TH } & BOX OTHER & 0 & 2022 & 0 & 697 & 0 & 1961 \\
\hline & & (n) & $\cdots$ & (n)..... & $\cdots$ & $\cdots$ & $\ldots \ldots$ \\
\hline Total for & HC_202A_TH & 0 & 1022 & 0 & 697 & 0 & 1961 \\
\hline \multirow[t]{4}{*}{ TWHC_221T } & $4 \times 4 \times 8$ 80X & 0 & 893 & 0 & 0 & 340 & 9564 \\
\hline & 55 GAL DRUM & 0 & 0 & 0 & 212 & 0 & 1062 \\
\hline & BOX OTHER & 0 & 893 & 0 & 0 & 340 & 9564 \\
\hline & & $\cdots$ & (n) & $\cdots$ & $\cdots \cdots$ & $\cdots$ & $\cdots$ \\
\hline \multicolumn{2}{|c|}{ Total for TWHC_221T } & 0 & 1706 & 0 & 212 & 680 & 20190 \\
\hline \multirow[t]{4}{*}{ THHC_222S } & 55 GAL DRUM & 0 & 0 & 0 & 0 & 0 & 9113 \\
\hline & BOX OTHER & 0 & 0 & o & o & o & 3763 \\
\hline & SWB & 0 & 0 & 0 & - & 0 & 76 \\
\hline & & $\cdots$ & $\cdots$ & $\cdots$ & $\cdots \cdots$ & $\cdots$ & (n) \\
\hline Total for & HHC_222S & 0 & 0 & 0 & 0 & 0 & 12951 \\
\hline \multirow{3}{*}{ THHC_225B } & $4 \times 4 \times 8$ BOX & 0 & 560 & 0 & 0 & 0 & 2830 \\
\hline & BOX OTHER & 0 & 1152 & 6847 & 0 & 0 & 40342 \\
\hline & & $\cdots \cdots$ & $\cdots$ & $\cdots$ & $\cdots \cdot \cdot$ & $\cdots$ & $\cdots$ \\
\hline \multicolumn{2}{|c|}{ Total for THHC_225B } & 0 & 1720 & 6847 & 0 & 0 & 43180 \\
\hline \multirow[t]{4}{*}{ TWHC_23452 } & $4 \times 4 \times 8$ BOX & 0 & 0 & 0 & 314 & 31 & 1724 \\
\hline & 55 GAL DRUM & 0 & o & 0 & 31 & 0 & 157 \\
\hline & BOX OTHER & 0 & 0 & 0 & 1821 & 2479 & 21499 \\
\hline & $\cdot \cdot$ & $\cdots$ & $\cdots$ & $\cdots$ & $\cdots \cdots$ & $\cdots$ & (........ \\
\hline \multicolumn{2}{|c|}{ Total for TWHC_2345Z } & 0 & 0 & 0 & 2166 & 2510 & 23381 \\
\hline \multirow[t]{2}{*}{ TWHC_242A } & $4 \times 4 \times 8$ Box & 0 & 0 & 0 & o & 0 & 35 \\
\hline & BOX OTHER & 0 & 0 & 0 & 0 & 0 & 313 \\
\hline
\end{tabular}


Maste Clase volume $\left(m^{\wedge} 3\right)$ by

Contalner Category and Maste Generator

\begin{tabular}{|c|c|c|c|c|c|c|c|}
\hline Waste denerator & Container Category & RH_LLH_GTCIII & RH_LLH_I & RH_LLW_III & RH_TRU & RH_TRUM & Total \\
\hline 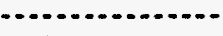 & - & - & $\cdots$ & - n & 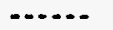 & $\ldots \ldots$ & ....... \\
\hline \multirow{2}{*}{\multicolumn{2}{|c|}{ Total for THHC_242A }} & -.....- & -....- & -...- & $-\cdots,-$ & $-\cdots-$ & - \\
\hline & & 0 & 0 & 0 & 0 & 0 & 348 \\
\hline \multirow[t]{2}{*}{ THIC_242S } & 4x4x8 BOX & o & 0 & 0 & 0 & 0 & 35 \\
\hline & BOX OTHER & 0 & 0 & 0 & 0 & 0 & 313 \\
\hline & & & $\cdots$ & $\cdots$ & - & $\cdots$ & 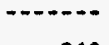 \\
\hline Total for & HC_242S & 0 & 0 & 0 & 0 & o & 348 \\
\hline \multirow[t]{3}{*}{ TWHC_242T } & $4 \times 4 \times 880 x$ & 0 & 0 & 0 & 0 & 0 & 8 \\
\hline & BOX OTHER & 0 & 0 & o & 0 & 0 & 68 \\
\hline & & $\ldots . .$. & ...... & $-\cdots$ & $\ldots$ & $\cdots$ & $\ldots$ \\
\hline Total for & HC_242T & 0 & 0 & 0 & 0 & 0 & 76 \\
\hline \multirow[t]{2}{*}{ TKHC_306 } & $4 \times 4 \times 880 x$ & o & o & o & 0 & o & 5 \\
\hline & & $\cdots--$ & $\cdots \cdots$ & $\cdots \cdots$ & $\cdots$ & $\cdots$ & $\cdots+\cdots$ \\
\hline Total for: & HC_306 & 0 & 0 & o & 0 & 0 & 5 \\
\hline \multirow[t]{3}{*}{ TWHC_300 } & $4 \times 4 \times 8$ Box & 0 & 0 & 0 & 0 & o & 116 \\
\hline & 55 ONL DRUM & 0 & 0 & 0 & 0 & o & 98 \\
\hline & swB & 0 & 0 & 0 & 0 & 0 & 5 \\
\hline \multirow{2}{*}{ Total for } & & $-\ldots$ & $\cdots$ & $\cdots$ & $\cdots$ & - & -....- \\
\hline & HC_308 & 0 & 0 & 0 & $\mathbf{0}$ & 0 & 219 \\
\hline \multirow[t]{3}{*}{ TWHC_340 } & BOX $128-500$ & 0 & 0 & 0 & 0 & 0 & 198 \\
\hline & BOX OTHER & $\underline{0}$ & 0 & o & 0 & 23 & 23 \\
\hline & & -..... & ........ & ........ & $\ldots$ & .......... & ......... \\
\hline Total for T & HC_340 & o & 0 & 0 & 0 & 23 & 221 \\
\hline TWHC_GROUT & $4 \times 4 \times 8$ BOX & 0 & 8 & 0 & o & 0 & 284 \\
\hline Total for & HC_GROUT & 0 & - & 0 & 0 & 0 & 284 \\
\hline TWHC_HWVP & $4 \times 4 \times 8$ BOX & 0 & 0 & 6626 & 0 & 0 & 8099 \\
\hline
\end{tabular}


Waste Class volume $\left(\mathrm{m}^{\wedge} \mathrm{3}\right)$ by

Contalner Category and Maste Generator

\begin{tabular}{|c|c|c|c|c|c|c|c|}
\hline Maste Generator & Container Category & RH_LLH_GTCIII & RH_LLH_I & RH_LLW_III & RH_TRU & RH_TRUM & Total \\
\hline - & 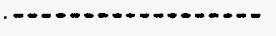 & - nen & -......... & a........... & $\ldots .$. & -....... & - n..... \\
\hline \multirow[t]{4}{*}{ TWHC_HWVP } & 55 GA DRUA & 0 & 0 & 0 & 716 & 0 & 716 \\
\hline & BOX OTHER & o & o & 0 & 6428 & 0 & .6428 \\
\hline & SWB & 0 & o & 0 & 11 & o & 71 \\
\hline & & $\cdots$ & (n....... & $\cdots$ & $\cdots$ & 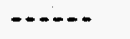 & $\cdots$ \\
\hline \multicolumn{2}{|c|}{ Total for TwHC_HWVP } & 0 & 0 & 6626 & 7215 & 0 & 15314 \\
\hline \multirow[t]{2}{*}{ TWHC_PX_CO18H } & $4 \times 4 \times 880 x$ & 0 & 0 & 0 & 0 & 0 & 2599 \\
\hline & & $\cdots$ & $\cdots \cdots$ & $\cdots$ & $\cdots+\cdots$ & $\cdots$ & $\cdots+-$ \\
\hline \multicolumn{2}{|c|}{ Total for TWHC_PX_CO18H } & 0 & 0 & 0 & 0 & 0 & 1599 \\
\hline \multirow[t]{3}{*}{ TWHC_TRUSAF } & $4 \times 4 \times 800 x$ & 0 & 0 & 0 & 0 & 0 & 7 \\
\hline & BOX OTHBR & 0 & 0 & 0 & 0 & 0 & 6 \\
\hline & & $\cdots+. .-$ & $\cdots$ & 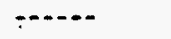 & -..... & $\cdots$ & -....... \\
\hline \multicolumn{2}{|c|}{ Total for TwHC_TRUSAP } & 0 & 0 & 0 & 0 & 0 & 13 \\
\hline \multirow[t]{2}{*}{ U_u } & 55 GNe DRUM & 0 & 0 & 0 & $\mathbf{0}$ & 0 & 12 \\
\hline & & (n...- & $\cdots$ & $\cdots$ & $\cdots$ & $\cdots$ & n....... \\
\hline \multicolumn{2}{|c|}{ Total for U_U } & 0 & $\circ$ & 0 & 0 & o & 12 \\
\hline \multirow[t]{5}{*}{ WHC_100 } & 30 CAL DRUM & 0 & 0 & 0 & 0 & 0 & 1 \\
\hline & 4x4x8 Box & 0 & 236 & 0 & o & 0 & 960 \\
\hline & 55 GAL DRUM & 0 & 0 & 0 & 0 & 0 & 761 \\
\hline & $B 0 x<128$ & 0 & 0 & 0 & 0 & 0 & 1 \\
\hline & & $\cdots$ & -...... & $\cdots$ & $\ldots . . .$. & $\cdots$ & -...... \\
\hline \multicolumn{2}{|c|}{ Total for MHC_L200 } & 0 & 136 & 0 & 0 & 0 & 1723 \\
\hline \multirow[t]{7}{*}{ KHC_100K } & $10 \mathrm{FT3}$ ION $\mathrm{EX}$ & 0 & 193 & 0 & 11 & 0 & 204 \\
\hline & 277 FT3 ION EX & 0 & 0 & 0 & 0 & 0 & 1406 \\
\hline & 30 GAL DRUM & 0 & 0 & 0 & 0 & 0 & 0 \\
\hline & $4 \times 4 \times 8$ BOX & 0 & 0 & 0 & 0 & 0 & 122 \\
\hline & 55 GAL DRUM & 0 & 0 & 0 & 0 & 0 & 1085 \\
\hline & $B O x<128$ & 0 & 0 & 0 & 0 & 0 & 1 \\
\hline & BOX OTHER & 0 & 236 & 0 & 125 & 0 & 360 \\
\hline
\end{tabular}


Maste clasa Volume $\left(m^{\wedge} 3\right)$ by

Contalner Category and Waste Generator

\begin{tabular}{|c|c|c|c|c|c|c|c|}
\hline Waste Generator & Contalner Category & RH_LLH_OTCIIt & RH_LLH_I & RH_LLH_III & RH_TRU & RH_TRUM & Total \\
\hline (n) & - & (n) & -......... & c........... & -..... & $\cdots$ & $\cdots+$ \\
\hline \multirow[t]{2}{*}{ HHC_100R } & OTHER DRUMS & 0 & 0 & 0 . & 0 & 0 & 0 \\
\hline & & $\cdots$ & $\cdots+\cdots$ & - & $\cdots$ & $\cdots$ & $\cdots$ \\
\hline Total for & C_100R & 0 & 429 & 0 & 136 & 0 & 3180 \\
\hline WHC_105DR & 55 GAL DRUM & 0 & 0 & 0 & 0 & 0 & 1 \\
\hline Total tor & C $105 \mathrm{DR}$ & 0 & 0 & $\cdots$ & 0 & $\cdots$ & 1 \\
\hline \multirow[t]{3}{*}{ WHC_202A } & $4 \times 4 \times 8$ Box & 0 & o & 0 & 0 & 0 & 194 \\
\hline & 55 GAL DRUM & 0 & 0 & 0 & 0 & 0 & 303 \\
\hline & SWB & 0 & 0 & 0 & 0 & 0 & 77 \\
\hline . & & 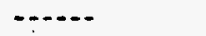 & $\cdots$ & $\cdots$ & -- & - & $\cdots$ \\
\hline Total for 1 & C_202A & 0 & o & 0 & 0 & 0 & 575 \\
\hline \multirow[t]{2}{*}{ HHC_221HB } & 30 GAL DRUM & 0 & 0 & 0 & 0 & 0 & 0 \\
\hline & & $\cdots \cdots$ & $\cdots--$ & $\cdots-$ & $\cdots$ & -- & - \\
\hline Total for & C_221HB & 0 & 0 & 0 & o & 0 & 0 \\
\hline \multirow[t]{3}{*}{ HHC_221T } & $4 \times 4 \times 8$ Box & 0 & o & 0 & 0 & 0 & 1076 \\
\hline & 55 GAL DRUM & 0 & 227 & 0 & 0 & 28 & 1232 \\
\hline & & $\ldots .$. & $\ldots . .$. & 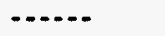 & $\cdots .$. & $\cdots \cdots$ & $\cdots-\cdot-$ \\
\hline \multicolumn{2}{|c|}{ Total for WHC_221T } & 0 & 227 & 0 & 0 & 28 & 2308 \\
\hline \multirow[t]{3}{*}{ WHC_222S } & $4 \times 4 \times B$ BOX & 0 & 0 & $\mathbf{0}$ & o & 0 & 15345 \\
\hline & 55 GAL DRUM & 0 & 0 & o & 0 & 0 & 5935 \\
\hline & & $\cdots$ & $\cdots+$ & 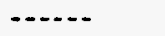 & $\cdots$ & $\cdots+-$ & -...... \\
\hline \multicolumn{2}{|c|}{ Total for WHC_222s } & 0 & 0 & $\mathbf{0}$ & 0 & 0 & 21280 \\
\hline \multirow[t]{4}{*}{ WHC_225B } & $4 \times 4 \times 8$ BOX & 0 & 0 & 0 & 0 & 0 & 84 \\
\hline & 55 GAL DRUM & 0 & o & 0 & 0 & 0 & 50 \\
\hline & BOX $128-500$ & 0 & 0 & 5 & 0 & 0 & 44 \\
\hline & $B O X<128$ & 0 & 0 & 0 & 0 & 0 & 46 \\
\hline
\end{tabular}


Waste Class volume $\left(\mathrm{m}^{\wedge} \mathrm{3}\right)$ by

Container Category and Waste Generator

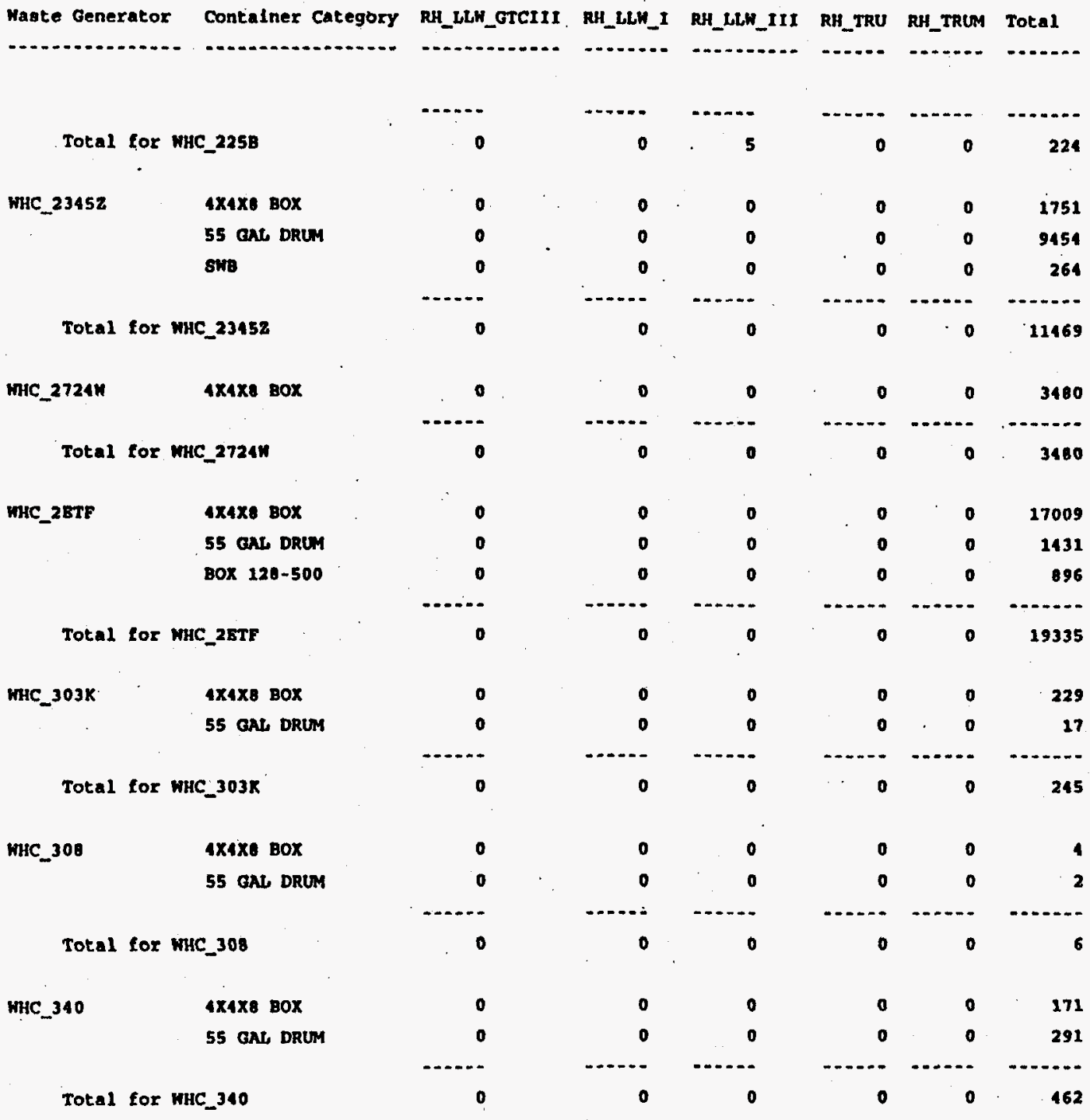


Wagte class Volume $\left(m^{\wedge} 3\right)$ by

Contalner Category and waste Generator

Waste Generator

contalner Category RH_LL_GTCIII RH_LLH_I RH_HLH_III RH_TRU RH_TRUM Total

\begin{tabular}{|c|c|c|c|c|c|c|c|}
\hline \multirow[t]{3}{*}{ WHC_377 } & 4x4x8 & 0 & 0 & 0 & 0 & 0 & 7 \\
\hline & 55 GAL DRUM & 0 & 0 & 0 & o. & 0 & 19 \\
\hline & BOX OTHER & 0 & 0 & 0 & 0 & 0 & 3 \\
\hline \multirow{2}{*}{\multicolumn{2}{|c|}{ Total for WHC_377 }} & $\cdots$ & n..... & $\cdots \cdots$ & -..... & $\cdots$ & $\cdots$ \\
\hline & & 0 & 0 & 0 & 0 & 0 & 29 \\
\hline \multirow[t]{6}{*}{ NHC_EKLOO } & $4 \times 4 \times 8$ Box & 0 & 0 & 0 & 0 & 0 & 745 \\
\hline & 55 GAL DRUM & 0 & 0 & 0 & 0 & 0 & 430 \\
\hline & $80 \times \quad 128-500$ & 0 & 0 & 0 & 0 & 0 & 10 \\
\hline & Box $500-1000$ & 0 & 0 & 0 & 0 & 0 & 15 \\
\hline & OTHER DRUNAS & 0 & 0 & 0 & 0 & 0 & 1 \\
\hline & & (n...... & (n)........ & (n)..... & $\cdots$ & $\cdots$ & (........ \\
\hline Total fox & MHC_BKLDO & 0 & 0 & 0 & 0 & 0 & 1200 \\
\hline \multirow[t]{2}{*}{ HHC_BQUIP } & BOX OTHER & 0 & 0 & 0 & 0 & 0 & 7663 \\
\hline & & - n.... & $\ldots$ & ...... & $\cdots$ & $\cdots$ & -....... \\
\hline Total tor & MHC_BQUIP & 0 & 0 & 0 & 0 & 0 & 7663 \\
\hline \multirow[t]{2}{*}{ WHC_DSTPSRET } & 55 GAL DRUM & 0 & 0 & 0 & 0 & 0 & 1 \\
\hline & WHC_DSTPSRET & 0 & 0 & 0 & 0 & 0 & $\cdots$ \\
\hline \multirow[t]{2}{*}{ WHC_DST_PRT } & CASKS & 0 & 0 & 0 & 0 & 18414 & 18414 \\
\hline & & $\cdots$ & $\cdots+$ & $\cdots-$ & $\cdots$ & $\cdots+$ & $\cdots+-$ \\
\hline Total for & HHC_DST_PRT & 0 & 0 & 0 & 0 & 18414 & 18414 \\
\hline \multirow{2}{*}{ WHC_DST_RET } & 55 GAL DRUM & 0 & .0 & 0 & 0 & 0 & 673 \\
\hline & & ....... & -...... & $\cdots$ & $\cdots$ & $\cdots$ & -....... \\
\hline Total for & WHC_DST_RET & 0 & 0 & 0 & o & 0 & 673 \\
\hline \multirow{3}{*}{ HHC_EA_H112 } & 55 OAL DRUM & 0 & 0 & 0 & 0 & 0 & 38 \\
\hline & & $\cdots$ & ....... & n.... & -- & $\cdots$ & 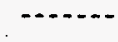 \\
\hline & WHC EA_M112 & 0 & 0 & 0 & 0 & 0 & 30 \\
\hline
\end{tabular}


Haste Class volume $\left(\mathrm{m}^{+} \mathrm{3}\right)$ by

Containex Category and Maste Generator

\begin{tabular}{|c|c|c|c|c|c|c|c|}
\hline Maste Generator & Contalner Category & RH_LLH_GTCIII & RH_LLW_T & RH_LLW_IIt & RH_TRU & RH_TRUM & Total \\
\hline - & n & n & (n) & (n).............. & $\cdots$ & (n....... & $\cdots+-$ \\
\hline HHC_EA_H213 & 55 GAL DRUM & 0 & 0 & o & 0 & $\mathbf{0}$ & 46 \\
\hline \multicolumn{2}{|c|}{ Total for WHC_EA_H113 } & o & 0 & o & 0 & 0 & 46 \\
\hline$M H C_{-}$EA_M221 & 5S OAL DRUN & 0 & o & 0 & 0 & 0 & 103 \\
\hline \multicolumn{2}{|c|}{ Total for MHC_EA_W221 } & o & o & 0 & o & 0 & 183 \\
\hline \multirow[t]{4}{*}{ MHC_FFTF_MAIMT } & $\operatorname{ex4x0}$ Box & o & 0 & 0 & 0 & 0 & 110 \\
\hline & 53 GNS DRUM & 0 & o & 0 & 0 & 0 & 151 \\
\hline & casks & o & 0 & 1065 & D & o & 1065 \\
\hline & & $\cdots$ & (n) & (n) & - & 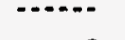 & (n) \\
\hline \multicolumn{2}{|c|}{ Total for WHC_FFTF_MAINT } & 0 & o & 1065 & 0 & o & 1326 \\
\hline \multirow[t]{7}{*}{ WHC_GROUT } & 4x4x: BOX & 0 & 0 & 0 & 0 & o & 3654 \\
\hline & 55 ORL DRUM & o & 0 & o & 0 & 0 & 1148 \\
\hline & BOX $228-500$ & 0 & o & o & o & 0 & 137 \\
\hline & Box $500-1000$ & 0 & - & 0 & 0 & 0 & 485 \\
\hline & $B 0 X<128$ & o & 0 & o & 0 & o & 14 \\
\hline & BOX $>1000$ & o & 0 & o & o & 0 & 132 \\
\hline & CASKS & 0 & 0 & o & o & 0 & 3658 \\
\hline & & ....... & -..... & $\cdots . .$. & 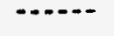 & $\cdots$ & $-\cdots . .$. \\
\hline \multicolumn{2}{|c|}{ Total for MHC_GROUT } & 0 & 0 & 0 & 0 & 0 & 9229 \\
\hline \multirow[t]{5}{*}{ WHC_HWVP } & $4 \times 4 \times 8$ 80X & 0 & 0 & 1191 & 0 & D & 15870 \\
\hline & 55 GAL DRUM & o & 0 & 1807 & 400 & 401 & 20345 \\
\hline & BOX OTHER & 0 & 0 & 0 & 0 & 0 & 210 \\
\hline & SHB & 0 & 0 & 0 & 1026 & 1027 & 2212 \\
\hline & & -..... & (n........ & n....... & - & $\cdots$ & $\cdots--\cdot$ \\
\hline \multicolumn{2}{|c|}{ Total for WHC_HWVP } & 0 & 0 & 2999 & 1426 & 1429 & 38637 \\
\hline MHC_LO45H & 55 GAL DRUM & 0 & 0 & o & 0 & 0 & 6261 \\
\hline
\end{tabular}


Haste Class Volume $\left(m^{\wedge} 3\right)$ by

Contalner Category and waste Generator

\begin{tabular}{|c|c|c|c|c|c|c|c|}
\hline Waste Generator & Contalner Category & RH_LLH_GTCIII & RH_LLH_I & RH_LLH_III & RH_TRU & RH_TRUM & Total \\
\hline - & - & non & (n............ & 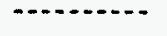 & -....- & -...... & $\cdots+$ \\
\hline \multirow{2}{*}{\multicolumn{2}{|c|}{ Total for MHC_LO45H }} & (n) & -..... & -..... & $\cdots .$. & -...... & -....... \\
\hline & & 0 & 0 & 0 & 0 & 0 & 6261 \\
\hline \multirow[t]{4}{*}{ WHC_LtBo } & 55 GNL DRUM & 0 & o & 0 & 0 & 0 & 19 \\
\hline & B-25 Box & 0 & 0 & 0 & 0 & 0 & 170 \\
\hline & $B O X<128$ & 0 & 0 & 0 & 0 & 0 & 34 \\
\hline & & & $\cdots$ & $\cdots$ & $\cdots$ & $\cdots$ & $\cdots+\cdots$ \\
\hline \multicolumn{2}{|c|}{ Total for HHC_LLBO } & - & 0 & 0 & 0 & 0 & 223 \\
\hline \multirow[t]{4}{*}{ พHC_EX_CO184 } & $4 \times 4 \times 0$ в0x & 0 & o & 0 & 0 & 0 & 210 \\
\hline & 55 GAL DRUM & 0 & 0 & o & 0 & o & 5385 \\
\hline & $B O X<228$ & 0 & 0 & 0 & 0 & 0 & 167 \\
\hline & & $\cdots$ & 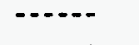 & -- & $-\cdot$ & - & $\cdots \cdots$ \\
\hline \multicolumn{2}{|c|}{ Total for MHC_PX_CO18H } & 0 . & o & 0 & 0 & 0 & 5762 \\
\hline \multirow[t]{3}{*}{ MHC_SSTRET } & $4 \times 4 \times 8$ BOX & 0 & 0 & $0^{\circ}$ & o & 0 & 591 \\
\hline & 55 GAL DRUM & o & 0 & 0 & $0^{\circ}$ & 0 & 293 \\
\hline & & 0 & -- & 0 & 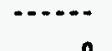 & - & 085 \\
\hline \multicolumn{2}{|c|}{ Total for WHC_SSTRET } & 0 & 0 & 0 & 0 & 0 & 885 \\
\hline \multirow[t]{7}{*}{ WHC_SURPLS_FAC } & $4 \times 4 \times 8$ 80X & 0 & 0 & 0 & 0 & 0 & 582653 \\
\hline & 55 GAL DRUM & 0 & o & 0 & 3 & 708 & 58785 \\
\hline & $B O X>1000$ & 0 & o & 0 & 0 & 0 & 25035 \\
\hline & BOX OTHER & 0 & 0 & 0 & o & 0 & 285532 \\
\hline & OTHER CYL & 39943 & o & o & 0 & 0 & 39943 \\
\hline & OTHER DRUMS & 0 & 0 & 0 & 0 & $\mathbf{0}$ & 229598 \\
\hline & & $\cdots$ & n..... & -....- & $\cdots$ & 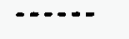 & ......... \\
\hline \multicolumn{2}{|c|}{ TOtal for WHC_SURPLS_FAC } & 39943 & 0 & 0 & 3 & 708 & 1121547 \\
\hline \multirow[t]{3}{*}{ HHC_TRUSAF } & 55 GAL DRUM & o & 0 & 0 & 0 & 0 & 3 \\
\hline & B-25 BOX & 0 & 0 & 0 & 0 & 0 & 12 \\
\hline & IC_TRUSAF & 0 & 0 & 0 & 0 & 0 & 15 \\
\hline
\end{tabular}


Naste Class Volume $\left(m^{\wedge} 3\right)$ by

Container Category and Haste Generator

\begin{tabular}{|c|c|c|c|c|c|c|c|}
\hline Maste Generator & Contalner Category & RH_LLW_GTCIII & RH_LLH_I & RH_LLH_III & RH_TRU & RH_IRUM & Total \\
\hline 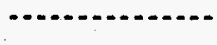 & " & (n) & (n) & n. & $\cdots+\cdots$ & $\cdots+\cdots$ & $\cdots \cdots$ \\
\hline \multirow[t]{3}{*}{ WHC_THP_106C } & $4 \times 4 \times 8$ BOX & - & 0 & 0 & 0 . & 0 & 902 \\
\hline & S5 GAL DRUM & 0 & 0 & 0 & 0 & 0 & 21 \\
\hline & & $\cdots$ & (n) & $\cdots .$. & $\cdots$ & $\cdots$ & -......- \\
\hline \multicolumn{2}{|c|}{ Total for WHC_TWP_106C } & 0 & 0 & 0 & 0 & o. & 422 \\
\hline \multirow[t]{2}{*}{ MHC_TWP_M020 } & $4 \times 4 \times 0$ Box & 0 & 0 & 0 & 0 & 0 & 58 \\
\hline & & $\cdots$ & $\cdots$ & $\cdots \cdots$ & $\cdots$ & $\cdots$ & ........ \\
\hline \multicolumn{2}{|c|}{ Total for MHC_TWP_M028 } & 0 & 0 & 0 & .0 & 0 & 50 \\
\hline$\cdot \cdot \cdot$ & & & & & & & \\
\hline \multirow{3}{*}{ HHC_THP_Y030 } & $4 \times 4 \times 8$ Box & 0 & 0 & 0 & 0 & 0 & 54 \\
\hline & 55 car DRuM & 0 & 0 & 0 & 0 & 0 & 21 \\
\hline & & $\cdots$ & (n....... & $\cdots$ & $\cdots$ & -- & $\cdots$ \\
\hline Total for & IC_TWP_H030 & 0 & 0 & 0 & 0 & 0 & 75 \\
\hline \multirow[t]{2}{*}{ HHC_TKP_H05B } & $4 \times 4 \times \theta B O X$ & 0 & 0 & 0 & $\mathbf{0}$ & 0 & 109 \\
\hline & & $\cdots$ & $\cdots$ & $\cdots$ & $\ldots \ldots$ & $\cdots$ & n....... \\
\hline Total for & IC_THP_H058 & 0 & 0 & 0 & 0 & 0 & 109 \\
\hline \multirow[t]{3}{*}{ HHC_TWP_W062 } & $4 \times 4 \times 8 B 0 x$ & 0 & 0 & 0 & 0 & 0 & 4 \\
\hline & 55 GAL DRUM & 0 & 0 & 0 & 0 & 0 & 0 \\
\hline & & $\cdots$ & $\cdots$ & - & - & $\cdots$ & $\cdots$ \\
\hline Total for & IC_THP_N062 & 0 & 0 & 0 & 0 & 0 & 1 \\
\hline WHC_THP_W151 & 55 GAL DRUM & 0 & 0 & 0 & 0 & 0 & 4 \\
\hline Total for & IC_THP_M151 & 0 & 0 & 0 & 0 & 0 & 4 \\
\hline WHC_TWP_H211 & 55 GAL DRUM & 0 & 0 & 0 & 0 & 0 & 162 \\
\hline Total for & IC_TWP_W211 & 0 & 0 & 0 & 0 & 0 & 462 \\
\hline WHC_TWP_W314 & $4 \times 4 \times 0$ Box & 0 & 0 & 0 & 0 & o & 6197 \\
\hline
\end{tabular}


Waste Class volume $\left(\mathrm{m}^{\wedge} 3\right)$ by

Contalner Category and Maste Generator

\begin{tabular}{|c|c|c|c|c|c|c|c|}
\hline Waste Generatc & Contalner Category & RH_LLN_OTCIII & RH_LLH_I & RH_LLH_III & RH_IRU & RH_TRUM & Total \\
\hline & & -....- & & & & & \\
\hline \multicolumn{2}{|c|}{ Total for WHC_IWP_H314 } & o & o & 0 & 0 & o & 6197 \\
\hline \multirow[t]{2}{*}{ MHC_MELL_DRL } & $4 \times 4 \times 880 x$ & 0 & 0 & 0 & o. & o & 18 \\
\hline & 55 GAL DRUM & - & 23 & o & $0^{\circ}$ & o & 235 \\
\hline \multicolumn{2}{|c|}{ Total for HHC NBLL_ DRD } & 0 & 13 & 0 & o & 0 & 253 \\
\hline \multirow{2}{*}{\multicolumn{2}{|c|}{ Grand Total }} & 41035 & 5781 & 18509 & 14297 & 33580 & 1803701 \\
\hline & & ....... & ...... & ...... & ....... & $=-\ldots$ & man-m. \\
\hline
\end{tabular}


WHC-EP-0803

\section{APPENDIX $F$}

FY-1993 WASTE GENERATOR ABBREVIATION LIST

F-1 
WHC-EP-0803

Page Intentionally $B$ lank 


\begin{tabular}{|c|c|c|}
\hline $\begin{array}{c}\text { Waste Generator } \\
\text { Group }\end{array}$ & $\begin{array}{c}\text { Waste Generator } \\
\text { Abbreviation } \\
\end{array}$ & Waste Generator Name \\
\hline D\&D & SURPLUS FAC & ENV Restoration Operations \\
\hline$D \& D$ & TPNL 2312 & PNL - 231Z - D\&D \\
\hline D\&D & TPNL 242B/BL & PNL - 242 BIdg - D\&D \\
\hline$D \& D$ & TPNL 306W & PNL - 306W B1dg - D\&D \\
\hline$D \& D$ & TPNL 314 & PNL - 314 B1dg - D\&D \\
\hline$D \& D$ & TPNL 324 & PNL - 324 B1dg - D\&D \\
\hline D\&D & TPNL 326 & PNL - 326 B $7 \mathrm{dg}-\mathrm{D} \& D$ \\
\hline$D \& D$ & TPNL 327 & PNL - 327 B $7 d g-D \& D$ \\
\hline$D \& D$ & TPNL 331 & PNL - 331 B7dg - D\&D \\
\hline D\&D & TWHC $100 \mathrm{~N}$ & N-Reactor - D\&D \\
\hline D\&D & TWHC 202A & CP Purex \& U03-224U - D\&D \\
\hline$D \& D$ & TWHC 221T & T-P1 ant B1dg. - D\&D \\
\hline D\&D & TWHC $222 \mathrm{~S}$ & CP 222-S Lab - D\&D \\
\hline$D \& D$ & TWHC 225B & DWM B P7ant \& WESF - D\&D \\
\hline D\&D & TWHC $2345 Z$ & CP Pu Fin. Plant - D\&D \\
\hline$D \& D$ & TWHC 242A & A Evaporator - D\&D \\
\hline D\&D & TWHC $242 \mathrm{~S}$ & $S$ Evaporator - D\&D \\
\hline$D \& D$ & TKLC 242T & T Evaporator - D\&D \\
\hline D\&D & TWHC 306 & ARD 306E B7dg. FDL - D\&D \\
\hline$D \& D$ & TWHC 308 & ARD Fuel Fab. Bldg. - D\&D \\
\hline$D \& D$ & TWHC 340 & Liq Wst Handling Fac - D\&D \\
\hline D\&D & TWHC GROUT & DHM Grout Fac - D\&D \\
\hline D\&D & TWHC HWVP & PD Waste Vit Proj - D\&D \\
\hline D\&D & TWHC PX CO18H & Purex-242A Eff Tmt - D\&D \\
\hline$D \& D$ & TWHC TRUSAF & DWM Sol Wst Ops - D\&D \\
\hline D\&D & WHC 202A TW & CP Purex \& U03-224U Tunnel Wst \\
\hline Remedial Action & PAST PRAC REM & Past Practice Remediation \\
\hline Remedial Action & WHC WELL DRL & Environmental Projects \\
\hline Offsite Receipts & AMES & Ames Laboratory-Ames, Iowa \\
\hline Offsite Receipts & ANL E & Argonne Nat. Lab.-East \\
\hline Offsite Receipts & B LEHR DAV & Univ. of CA, Davis \\
\hline Offsite Receipts & BAPL & Bettis Atomic Power Laboratory \\
\hline Offsite Receipts & BAPL SHIPYDS & Bettis Atomic Power Shipyards \\
\hline Offsite Receipts & BAT CLBS LAB & Battelle Columbus Labs. \\
\hline Offsite Receipts & BRKHVN & Brookhaven \\
\hline Offsite Receipts & EG\&G & EG\&G Rocky Flats Plant \\
\hline Offsite Receipts & FERMI & FERMI Nat. Accelerator Lab. \\
\hline Offsite Receipts & FUSRAP & ORNL Oak Ridge National Lab. \\
\hline Offsite Receipts & GEN ATOM & General Atomics \\
\hline Offsite Receipts & KAPL SHIPYDS & Knolls Atomic Power Shipyards \\
\hline
\end{tabular}




\begin{tabular}{|c|c|c|}
\hline $\begin{array}{l}\text { Waste Generator } \\
\text { Group }\end{array}$ & $\begin{array}{c}\text { Waste Generator } \\
\text { Abbreviation }\end{array}$ & Waste Generator Name \\
\hline Offsite Receipts & LBL & Lawrence Berkeley Lab \\
\hline Offsite Receipts & LLNL & Lawrence Livermore Nat1 Lab \\
\hline Offsite Receipts & MIT BATES & Bates Accelerat.-Massachusetts \\
\hline Offsite Receipts & PADUCAH ES & Paducah Energy Systems \\
\hline Offsite Receipts & PADUCAH U & Paducah Utility Services \\
\hline Offsite Receipts & PORTSMOUTH & Gaseous Diffusion Plant \\
\hline Offsite Receipts & PRINCETON & Plasma Physics Laboratory \\
\hline Offsite Receipts & RKW CANOGA & Rockwell Canoga Park \\
\hline Offsite Receipts & STANFORD & Stanford Lin Accelerator Cntr \\
\hline Offsite Receipts & U U & Univ. of Utah \\
\hline Site Support & HEHF & Hanford Env. Health Found. \\
\hline Site Support & KEH 100 & Kaiser Engineers \\
\hline Site Support & PNL & Pacific Northwest Laboratory \\
\hline Site Support & WHC 100 & DRD 100 Area \\
\hline Site Support & WHC $100 \mathrm{~K}$ & K-Basin Operations \\
\hline Site Support & WHC 105DR & ARD Large Sodium Fire Facility \\
\hline Site Support & WHC 202A & CP Purex \& U03-224U Facilities \\
\hline Site Support & WHC 221HE & T-Plant Head End Cleanup \\
\hline Site Support & WHC 221T & T-P1 ant B1dg. $2706 / 221$ \\
\hline Site Support & WHC 222S & CP 222-S Laboratory \\
\hline Site Support & WHC 225B & B Plant/WESF Facilities \\
\hline Site Support & WHC $2345 Z$ & CP Pu Finishing Plant \\
\hline Site Support & WHC 2724W & Laundry-Equip. Decon Facility \\
\hline Site Support & WHC $303 \mathrm{~K}$ & Fuels Operations \\
\hline Site Support & WHC 308 & ARD Fuel Fabrication Bldg. \\
\hline Site Support & WHC 340 & Liquid Waste Handling Facility \\
\hline Site Support & WHC 377 & Geo. Tech. Engineering Lab. \\
\hline Site Support & WHC BQUIP & Buried Equipment \\
\hline Site Support & WHC EA W112 & SW RMW Storage Facility \\
\hline Site Support & WHC EA W113 & SW Retrieval Fac.-Phase 1 \\
\hline Site Support & WHC EA W221 & SW Retrieval Fac.-Phase 2 \\
\hline Site Support & WHC FFTF MAINT & FFTF/FMEF Maintenance. \\
\hline Site Support & WHC LO45H & 300 Area Water Treatment Proj. \\
\hline Site Support & WHC LLBG & DWM Low Level Burial Grounds \\
\hline Site Support & WHC PX COI8H & Purex242A Condensate Treatment \\
\hline Site Support & WHC TRUSAF & DWM Solid Waste Operations \\
\hline TWRS & LL EQUIP & Long-Length Equipment \\
\hline TWRS & LL EQUIP SEC & Long-Length Equipment Secondary Waste \\
\hline TWRS & WHC 2ETF & Single Shel1 Tank Farms \\
\hline TWRS & WHC BKLOG & Tank Farms Backlog Waste \\
\hline
\end{tabular}




\begin{tabular}{|l|l|l|}
\hline $\begin{array}{c}\text { Waste Generator } \\
\text { Group }\end{array}$ & \multicolumn{1}{|c|}{$\begin{array}{c}\text { Waste Generator } \\
\text { Abbreviation }\end{array}$} & \multicolumn{1}{|c|}{ Waste Generator Name } \\
\hline TWRS & WHC DST PRT & DST NCAW Process Tests (Pretreatment) \\
\hline TWRS & WHC DST RET & W343 DST Retrieval (17 Tanks) \\
\hline TWRS & WHC DSTPSRET & CC, PFPENCRWDST Pilot Scale Ret \\
\hline TWRS & WHC_GROUT & $\begin{array}{l}\text { DWM Grout Facility (LLW Treatment } \\
\text { Facility) }\end{array}$ \\
\hline TWRS & WHC HWVP & PD Waste Vitrification Project \\
\hline TWRS & WHC SSTLLE & SST Long Length Equipment \\
\hline TWRS & WHC SSTRET & SST Retrieval (458 tanks) \\
\hline TWRS & WHC TWP 106C & W320 Tank 241 STuicing \\
\hline TWRS & WHC TWP W028 & Aging Waste Transfer Lines \\
\hline TWRS & WHC TWP W030 & Tank Farm Ventilation Upgrade \\
\hline TWRS & WHC TWP W058 & Cross-Site Transfer Lines \\
\hline TWRS & WHC TWP W062 & Tank AP-104 Upgrade \\
\hline TWRS & WHC TWP W151 & Tank Farm-101-AZ Retrieval Sys \\
\hline TWRS & WHC TWP W211 & DST Retrieval (10 tanks) \\
\hline TWRS & WHC TWP W314 & Tank Farm Restoration \\
\hline \hline
\end{tabular}


WHC-EP-0803

This page intentionally left blank.

F-6 


\section{DISTRIBUTION}

Number of Copies

ONSITE

6

U.S. Department of Energy, Richland Field office

R. F. Guercia (5)

S7-55

Public Reading Room

A1-65

41

Pacific Northwest Laboratories

L. L. Armacost (25)

K8-18

M. C. Bierschbach

K7-97

C. L. Blackburn

T. J. DeForest

G. M. Holter (2)

J. A. Jamison

P. S. Kaae

H. S. Konynenbelt

D. K. Kreid

G. I. Rice

T. L. Ross

S. R. Shaver

D. L. Stiles

K. J. Templeton

$R$. R. Wehrman

N. C. Withams

L4-91

K7-97

K7-97

K8-18

K8-18

$\mathrm{K} 8-18$

$K 1-22$

K8-18

K8-18

K8-18

K8-18

K7-94

K8-18

K8-18

Westinghouse Hanford Company

J. D. Anderson

T3-04

H. C. Boynton

T3-04

A. B. Carlson

H5-33

F. M. Coony

H5-33

D. R. Duncan

H5-33

D. B. Encke

W. H. Hamilton, Jr.

$\times 5-55$

K. H. Hladek

N3-10

W. G. Jasen

D. M. Johnson

H5-33

R. S. Kelley

M. M. McCarthy

56-17

H5-33

D. L. Merrick

H5-33

E. P. Mertens

N3-13

R. D. Pierce

R2-85

J. G. Riddelle

N3-13

R. J. Roberts

T3-04

O. J. Valero (20)

N3-13

A. 0. Vance

H5-33

J. L. Westcott

H5-33

M. I. Wood

Document Processing \& Dist. (2)

Central Files

OSTI (2)

N3-13

N3-13

L8-15

L8-04

L8-07

Distr-1 